\title{
Assessment of the Labor Market Experiences of CETA-Trained Solar Workers
}

Barbara A. Burns

Bert Mason

Gail Y. Mikasa
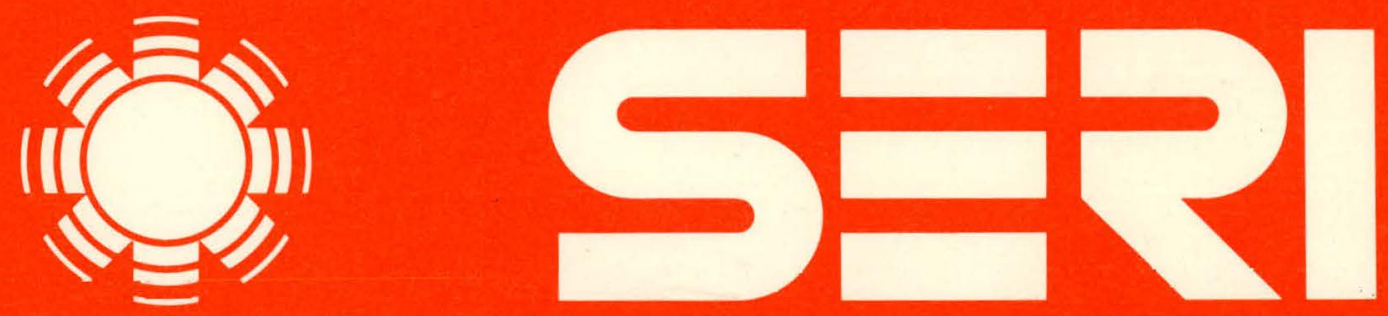

Solar Energy Research Institute

A Division of Midwest Research Institute

1617 Cole Boulevard

Golden, Colorado 80401

Operated for the

U.S. Department of Energy

under Contract No. EG-77-C-01-4042 


\section{DISCLAIMER}

This report was prepared as an account of work sponsored by an agency of the United States Government. Neither the United States Government nor any agency Thereof, nor any of their employees, makes any warranty, express or implied, or assumes any legal liability or responsibility for the accuracy, completeness, or usefulness of any information, apparatus, product, or process disclosed, or represents that its use would not infringe privately owned rights. Reference herein to any specific commercial product, process, or service by trade name, trademark, manufacturer, or otherwise does not necessarily constitute or imply its endorsement, recommendation, or favoring by the United States Government or any agency thereof. The views and opinions of authors expressed herein do not necessarily state or reflect those of the United States Government or any agency thereof. 


\section{DISCLAIMER}

Portions of this document may be illegible in electronic image products. Images are produced from the best available original document. 


\author{
Printed in the United States of America \\ Available from: \\ National Technical Information Service \\ U.S. Department of Commerce \\ 5285 Port Royal Road \\ Springfield, VA 22161 \\ Price: \\ Microfiche $\$ 3.00$
Printed Copy $\$ 2.25$ \\ $12,5^{-0}$
}

NOTICE

This report was prepared as an account of work sponsored by the United States Government. Neither the United States nor the United States Department of Energy, nor any of their employees, nor any of their contractors, subcontractors, or their employees, makes any warranty, express or implied, or assumes any legal liabiiity or responsibility for the accuracy, completeness or usefulness of any information, apparatus, product or process disciosed, or represents that its use would not infringe privately owned rigits. 
SERI/RR - .743-396

VOLUME II

UC CATEGORY: UC-58

ASSESSMENT OF THE LABOR

MARKET EXPERIENCES OF

CETA-TRAINED SOLAR

WORKERS

BARBARA A. BURNS

BERT MASON

GAIL Y. MIKASA

DECEMBER 1980

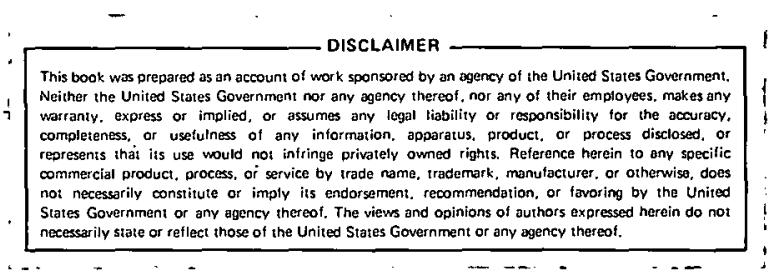

PREPARED UNDER TASK NO. 5635.30

\section{Solar Energy Research Institute}

A Division of Midwest Research Institute

1617 Cole Boulevard

Golden, Colorado 80401

Prepared for the

U.S. Department of Energy

Contract No. EG-77-C-01-4042 


\section{THIS PAGE}

\section{WAS INTENTIONALLY LEFT BLANK}




\section{PREFACE}

This report summarizes results of work perf ormed under the Solar Energy Research Institute's (SERI) Task Nos. 5379.11 (FY 1979) and 5635.30 (FY 1980), "Assessment of the Labor Market Experience of CETA-Trained Solar Workers." Barbara Burns and Bert Mason of SERI's Analysis and Applications Directorate were task co-leaders. The study was funded by the U.S. Department of Energy (DOE), Assistant Secretary for Energy Technology (FY 1979) and Assistant Secretary for Conservation and Solar Energy (FY 1980).

This project is part of a larger employment and training research effort, conducted by SERI, that includes review and development of data on solar energy labor requirements, survey and data-base formulation on training and education programs, and regional and national solar energy employment projections.

The report is divided into four major components: (1) a summary of the research approach and objectives, (2) descriptions of 12 solar training programs in California funded through the Comprehensive Employment and Training Act (CETA) program and summaries of information obtained from their directors about the operations of these programs, (3) an analysis of field data on the labor market experiences of 144 students from the California training programs, and (4) conclusions based on program and participant data and recommendations for community-based training efforts.

SERI staff members designed the research approach and field questionnaires, conducted field interviews with directors of the training program, and analyzed the data on the labor market experiences of program graduates. The State of California's SolarCal Office conduc ted field interviews with program graduates.

The authors wish to thank the staff of the California CETA solar training programs, graduates from these programs, and the SolarCal Office staff for their cooperation and participation in the project.

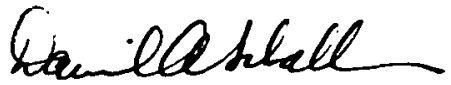

David A. Schaller, Acting Chief

Environmental and Social Impacts Branch

Approved for

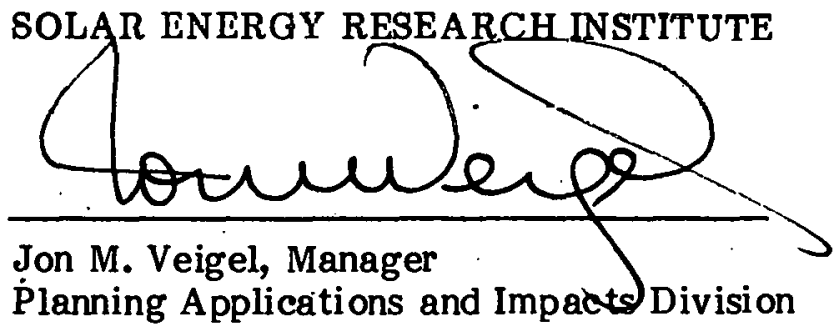


THIS PAGE

\section{WAS INTENTIONALLY LEFT BLANK}




\section{SUMMARY}

\section{OBJECTIVES}

This project had three major objec tives:

- To develop and test procedures that could be used to assess a generic type of solar training eff ort (CETA-sponsored programs) which has been included in federal programs (e.g., the DOE/DOL/CSA SUEDE program), and is funded by state CETA offices and prime sponsors;

- To provide in-depth descriptions of the California CETA solar training programs for persons planning or managing solar training programs, including issues such as union response and institutional arrangements for providing the training; and

- To describe and analyze the employment experiences of the graduates of the Calif ornia CETA solar training programs.

\section{DISCUSSION}

The project was an empirical study of the graduates of 12 CETA solar training programs in Calif ornia. Interviews with the program staffs and graduates were conducted in the summer of 1979, in cooperation with the State of California's SolarCal Office. The data were analyzed to answer three major questions: (1) How many and which of the graduates of CETA solar training programs are working now in solar energy-related jobs? (2) Do those graduates working in solar jobs think their training was adequate for the jobs? (3) What particular factors are related to the placement of graduates in solar jobs? Specific information on the graduates includes data about demographics, prior educational and work experience, satisfaction with the solar training, types of jobs found, wage levels, and job tenure. Program information includes program history, training schedules and content, selection of trainees, placement activities, instructor characteristics, relationships with outside groups, and problems.

\section{CONCLUSIONS AND RECOMMENDATIONS}

The results of this study are presented in four categories: program components and characteristics, curriculum design and implementation, student selection and characteristics, and participant experiences. The major program problems were found to be limited funding, shortages of trained instructors, insufficient staff support, a need for local employment information, the need for a better-defined role for unions, and pressures for high placement rates. All of the curricula involved a mixture of general skills, skills specific to solar technologies, and basic job behavior and job skills. The training involved both classroom and hands-on experience and was, in most cases, tailored to the participants and the local job market. Four issues regarding student selection were identified: the use of aptitude tests, the "skimming" of top applicants in order to maximize program success, the diversity or homogeneity of student skill levels, and the high expectations of the applicants. Successful job placement of the program participants was relatively high; over half the initial placements af ter training involved solar energy. Solar jobs appeared to pay more than nonsolar jobs. The participants were generally satisfied with their training and felt that it had prepared them adequately for their current work. 
Blank

vi 


\section{TABLE OF CONTENTS}

Page

1.0 Introduction: Overview and Background $\ldots \ldots \ldots \ldots \ldots \ldots \ldots \ldots \ldots \ldots \ldots$

2.0 Research Approach $\ldots \ldots \ldots \ldots \ldots \ldots \ldots \ldots \ldots \ldots \ldots \ldots \ldots \ldots \ldots \ldots \ldots \ldots$

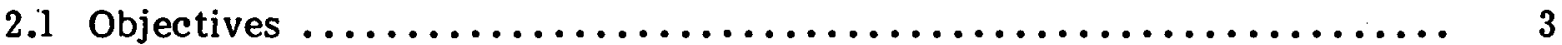

2.2 Technical Approach $\ldots \ldots \ldots \ldots \ldots \ldots \ldots \ldots \ldots \ldots \ldots \ldots \ldots \ldots \ldots \ldots \ldots \ldots$

2.3 Data Collection and Analysis Procedures ..................... 4

3.0 The California CETA Solar Training Programs.................. 7

3.1 Introduction and History of the California CETA Solar

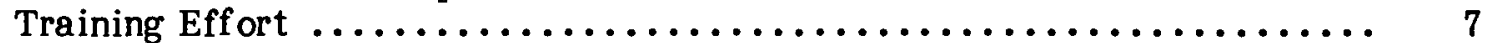

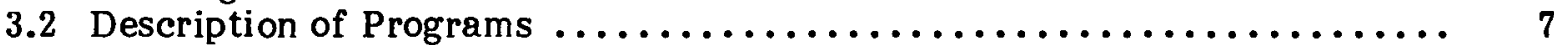

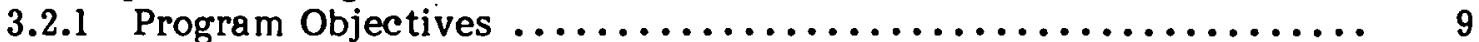

3.2.2 Funding Levels and Sources ........................ 9

3.2.3 Length and Intensity of Programs.................... 15

3.2.4 General Characteristics of Training.................... 15

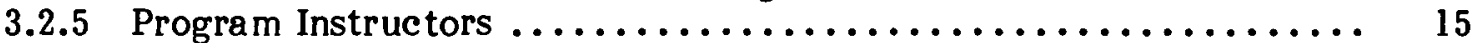

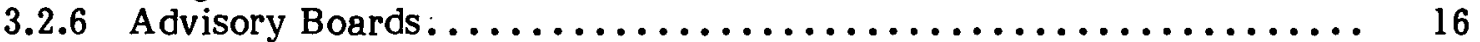

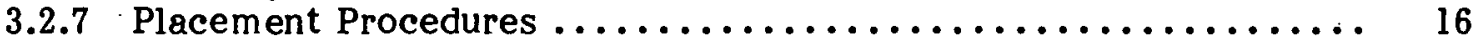

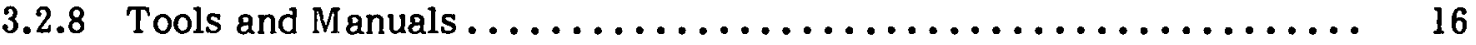

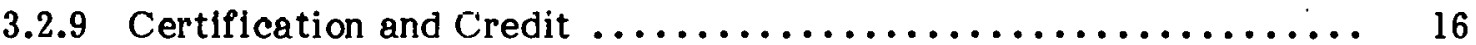

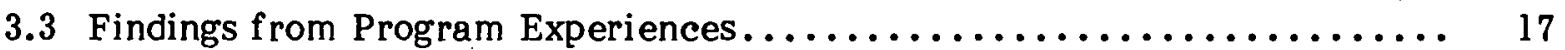

3.3.1 Program Components and Considerations ................ 17

3.3 .2 Curricula Design and Implementation ................... 18

3.3.3 Student Selection and Characteristics ................... 19

4.0 The Program Participants $\ldots \ldots \ldots \ldots \ldots \ldots \ldots \ldots \ldots \ldots \ldots \ldots \ldots \ldots \ldots \ldots \ldots$

4.1 Characteristics of the Participant Sample .................... 21

4.1.1 Demographic Characteristics ....................... 21

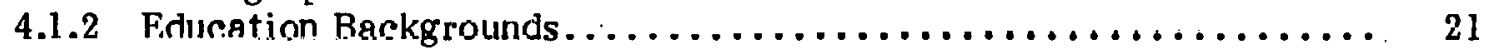

4.1.3 Employment Backgrounds ........................ 23

4.2 Participants' Experience with Programs .................... 28

4.2.1 Reasons for Participating in the CETA Solar Program .......... 28

4.2.2 Graduation from the CETA Programs .................. 28

4.2.3 Satisf action with the Programs..................... 28

4.2.4 Job Experience and the Training Program............... 28

4.3 Placement and Job Expericnecs ......................... 31

4.3.1 Length of Time Since Leaving Program................ 31

4.3.2 Type of Job (Post-Program)...................... 3 I

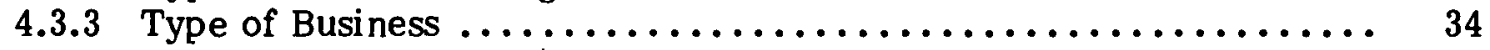

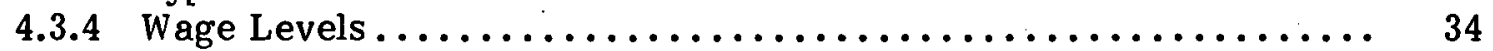

4.3.5 Hours per Week Employed ....................... 37

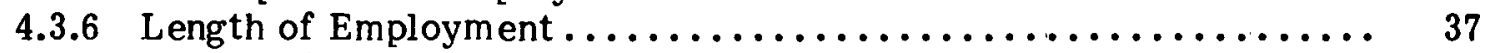

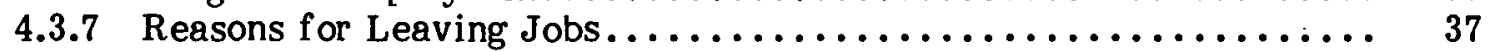

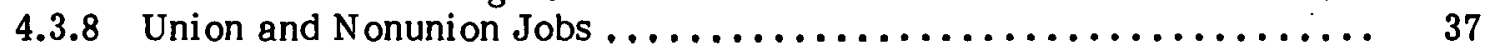

4.4 Solar Employment and Experience $\ldots \ldots \ldots \ldots \ldots \ldots \ldots \ldots \ldots \ldots \ldots \ldots \ldots$ 


\section{TABLE OF CONTENTS (concluded)}

$\underline{\text { Page }}$

4.4.1 Solar vs. Nonsolar Jobs......................... 37

4.4.2 Percentage of Job Time on Solar ..................... 38

4.4.3 Solar Installations Worked on by Participants.............. 38

4.5 Factors Affecting Placement Experience ................... 38

4.5.1 Type of Job vs. Previous Education ................. 45

4.5 .2 Type of Job vs. Sex.......................... 45

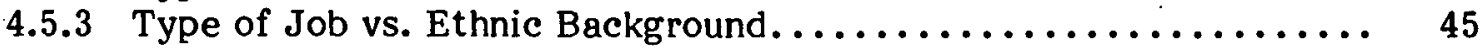

4.5.4 Solar Jobs vs. Previous Education.................. 45

4.5.5 Solar Jobs vs. Sex .......................... 51

4.5.6 Solar Jobs vs. Ethnic Background .................... 51

4.5.7 Sex and Age vs. Wage Rates ...................... 51

4.5 .8 Solar Jobs vs. Wage Rates ....................... 51

5.0 Conclusions and Recommendations $\ldots \ldots \ldots \ldots \ldots \ldots \ldots \ldots \ldots \ldots \ldots \ldots \ldots \ldots$

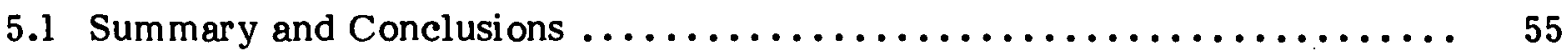

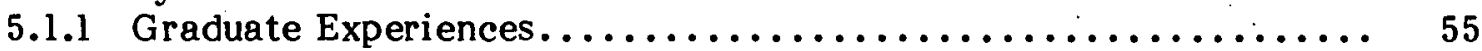

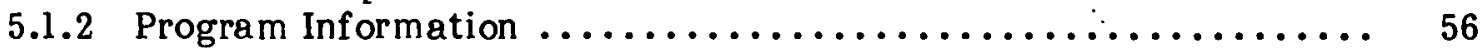

5.2 Recommendations .................................. 58

Appendix A - The Calif ornia Solar Effort ....................... 61

Appendix B - California CETA Solar Training Programs

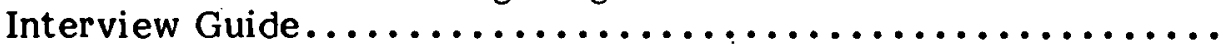

Appendix C - Comprehensive Employment and Training Act (CETA) .......... 83

Appendix $D$ - Job Category Definitions . . . . . . . . . . . . . . . .

Appendix E - Program Descriptions ......................... 91

E-1. The Firebox Solar Water Heating Program: Klamath River

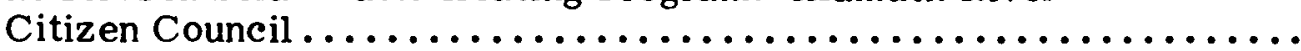

E-2. Solar Technician Training Program: Net Energy ................ 94

E-3. The Solar Demonstration Project: Lakeview Educational

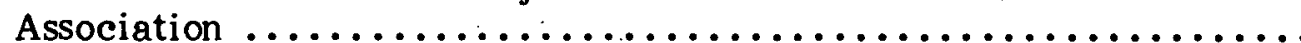

E-4. Solar Energy Technician Training Program: City of Richmond, Manpower Service.............................. 106

E-5. Solar Technician Training Program: Sky Ray Systems, Inc. ........ 113

E-6. Solar/Energy. Technician Training Program: Sonoma State

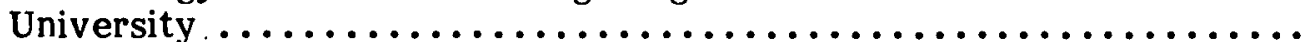

E-7. Solar Training and Utilization: Community Resource

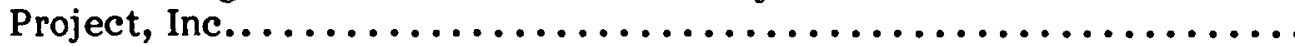

E-8. Solar Energy Project: San Mateo Economic Opportunity

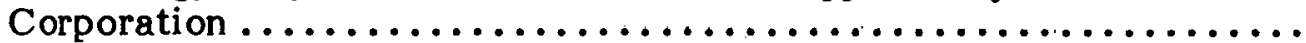

E-9. Solar Training Program: Proteus Adult Training, Inc. ........... 129

E-10. Solar Energy Project: San Bernardino Westside Community

Development Corp. ............................. 133

E-11. Solar Technician Training Program: Sacramento-Yolo........... 138 


\section{LST OF TABLES}

Page

2-1 Participants and Interviews by Program $\ldots \ldots \ldots \ldots \ldots \ldots \ldots \ldots \ldots \ldots \ldots \ldots$

3-1 Summary of California CETA Solar Training Programs ............... 10

3-2 Characteristics of Training $\ldots \ldots \ldots \ldots \ldots \ldots \ldots \ldots \ldots \ldots \ldots \ldots \ldots \ldots \ldots \ldots$

4-1 Ages of Participants $\ldots \ldots \ldots \ldots \ldots \ldots \ldots \ldots \ldots \ldots \ldots \ldots \ldots \ldots \ldots \ldots \ldots \ldots \ldots \ldots$

4-2 Numbers of Interviewees by Age, Sex, and Ethnic Background .......... 22

4-3 Education Levels of Program Participants ..................... 23

4-4 Fields of Study for Graduates with Post-High School Education ........... 24

4-5 Employment Training Prior to the CETA Programs................. 25

4-6 Types of Previous Training by Occupational Category $\ldots \ldots \ldots \ldots \ldots \ldots \ldots$

4-7 Types of Jobs Previously Held........................... 26

4-8 Most Recent Job Held Before Solar Training Program . . . . . . . . . . . . . 27

4-9 Number of Previous Employers Since Age $18 \ldots \ldots \ldots \ldots \ldots \ldots \ldots \ldots \ldots$

4-10 Different Kinds of Work Since Age $18 \ldots \ldots \ldots \ldots \ldots \ldots \ldots \ldots \ldots \ldots$

4-11 Participants' Reasons for Signing Up for Program .................. 29

4-12 Participants' Satisfaction with Program $\ldots \ldots \ldots \ldots \ldots \ldots \ldots \ldots \ldots \ldots \ldots \ldots$

4-13 Did the Training Program Adequately Prepare You for Current Work? ...... 31

4-14 Length of Time Since Graduation $\ldots \ldots \ldots \ldots \ldots \ldots \ldots \ldots \ldots \ldots \ldots \ldots \ldots \ldots$

4-15 Types of Jobs Held After Program $\ldots \ldots \ldots \ldots \ldots \ldots \ldots \ldots \ldots \ldots \ldots \ldots$

4-16 Types of Businesses Joined After Program . ..................... 35

4-17 Initial Hourly Wage Rates After Program $\ldots \ldots \ldots \ldots \ldots \ldots \ldots \ldots \ldots \ldots \ldots$

4-i8 Highest Hourly Wage Rates After Program ................... 36

4-19 Hours Per Week Employed, First Job After Program . . . . . . . . . . . . . . 39

4-20 Length of Employment, After Program ..................... 39

$4-21$ Reasons for Leaving Jobs............................. 40 
LIST OF TABLES (concluded)

$\underline{\text { Page }}$

4-22 Union Affiliations of Graduates $\ldots \ldots \ldots \ldots \ldots \ldots \ldots \ldots \ldots \ldots \ldots \ldots \ldots \ldots$

4-23 Did Post-Program Job Involve Solar Energy $\ldots \ldots \ldots \ldots \ldots \ldots \ldots \ldots \ldots \ldots \ldots \ldots \ldots$

4-24 Type of Job Held After Program, Solar vs. Nonsolar . . . . . . . . . . . . 42

4-25 Percentages of Time on Solar Work, For Graduates with Solar Jobs .................................. 43

4-26 Number of Solar Installations Done $\ldots \ldots \ldots \ldots \ldots \ldots \ldots \ldots \ldots \ldots \ldots \ldots$

4-27 Types of Systems Installed Since Leaving Program . . . . . . . . . . . . . 44

4-28 First Job by Highest Grade Completed in School ................. 46

$4-29$ First Job, by $\operatorname{Sex} \ldots \ldots \ldots \ldots \ldots \ldots \ldots \ldots \ldots \ldots \ldots \ldots \ldots \ldots \ldots \ldots \ldots \ldots$

4-30 First Job, by Racial/Ethnic Background .................... 49

4-31 Was Your First Job in Solar Energy Field? (by Grade in School)........... 50

4-32 Was Your First Job in Solar Energy Field? (by Sex) $\ldots \ldots \ldots \ldots \ldots \ldots \ldots$

4-33 Was Your First Job in Solar Energy Field? (by Ethnic Background) . . . . . . . 52

4-34 Top Wage Rate, First Job $\ldots \ldots \ldots \ldots \ldots \ldots \ldots \ldots \ldots \ldots \ldots \ldots \ldots \ldots \ldots \ldots \ldots$

4-35 Initial Wage Rate, First Job .......................... 54 


\section{SECTION 1.0}

\section{INTRODUCTION: OVERVIEW AND BACKGROUND}

The employment implications of solar energy commercialization are potentially important in at least two respects. First, significant market penetration of solar energy technologies may create jobs requiring skills different from those for conventional energy industries. Second, the extent of adoption, consumer acceptance, and competitiveness of solar technologies in energy markets may be affected by the availability of qualified and well-trained manpower to manufacture, design, and install solar equipment.

Although estimates of the job creation potential of solar energy vary widely, it is safe to predict that a rapidly expanding solar industry will provide significant employment opportunities for a variety of labor skills. A key concern in developing solar training efforts to meet this expanding demand is whether jobs in the solar industry can be targeted toward the unemployed or underemployed. The major premises supporting the assertion that solar energy will ultimately offer employment possibilities to CETA-eligible individuals are (1) a substantially new job market will be created that cannot be filled by existing labor market participants; and (2) individuals who do not have appropriate skills to compete in the current job market can be readily trained to manufacture, install, and maintain solar systems.

This study was undertaken to provide needed information about these issues by identifying the types of solar training being offered by CETA-funded programs and the labor market experiences of graduates from these programs. To reduce variation among environmental considerations such as climate, state incentives for solar energy, and a number of other variables, the initial research was conducted on programs within only one state-California.

California was chosen as the site for the initial project for a number of reasons. The state is currently involved in a variety of solar-related activities. These solar programs, which include job development and training, are summarized in Appendix A. California had, at the time the field work was conducted, a relatively large number (12) of CETA solar training programs, which provided a range of designs and characteristics. There have been more than 500 graduates from these programs (by December 1979), which is an adequate sample for collecting data on the labur market experiences of persons trained for solar jobs. Although the scope of the study is limited in terms of program type, institution (CETA), and geographic representation (California), information from the analysis should be useful to those with interest in solar training: federal, state, and local governments; educational institutions; the solar industry; and community groups.

The objectives and research plan for this project are presented in Sec. 2.0. In Sec. 3.0, we provide an overview of the training programs involved in this project and a summary of findings from interviews with program directors. In Sec. 4.0, data collected on the program participants and their labor market experiences are summarized and analyzed. In Sec. 5.0, major findings of the study are summarized and recommendations derived from these findings are provided. 


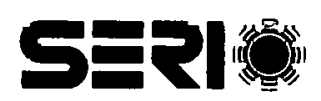




\section{SECTION 2.0}

\section{RESEARCH APPROACH}

\subsection{OBJBCTIVES}

The labor market assessment of CETA-trained solar workers has three major objectives:

- To develop and test procedures which could be used to assess a generic type of solar training effort (CETA-sponsored programs) which has been included in federal programs (e.g., the DOE/DOL/CSA SUEDE program) and is being funded by state CETA offices and prime sponsors;

- To provide in-depth descriptions of the California CETA solar training programs for persons planning or managing solar training programs, including union responses and institutional arrangements for providing training; and

- To describe and analyze the employment experiences of graduates of the California CETA solar training programs.

\subsection{TECHNICAL APPROACH}

The technical approach involves (1) reviewing the literature on evaluation of manpower and training programs, (2) designing and monitoring an empirical study of the California CETA solar training programs and their graduates, and (3) analyzing the data.

Information on the CETA programs was collected by the SERI project staff in June and July of 1979, using an interview guide. The interview guide for program participants was also developed by the SERI staff, but the actual interviews were conducted by the SolarCal Office, California State Government. (Copies of the interview guides are attached as Appendix B.) The data collection covered 12 California CETA solar training programs funded by the governor's discretionary funds, or by prime sponsors, or both.

The program and graduate interviews were developed and implemented to answer three main research questions:

(1) How many and which of the graduates of CETA solar training programs are working in solar energy-rela ted jobs?

(a) What types of solar jobs are they filling?

(b) What factors have restricted their ability to find solar jobs?

(c) What, if any, interaction with unions have they had?

(2) Are there particular characteristics of the training programs or participants that are related to the placement of graduates in solar jobs?

(3) Have those graduates working in solar jobs found that their CETA training provided adequate skills for their jobs?

To address these research questions, the interviews asked the following questions (see also Appendix B): 


\section{(1) Program Character istics}

(a) What are the objectives of the training program?

(b) What changes or modifications have occurred in the program, and why?

(c) What types of persons are participating in the program, and how are they selected?

(d) What are the characteristics of persons who do not complete the program?

(e) What is the content of the program (e.g., how much time is devoted to hands-on experience and in what setting)?

(f) What types of placement assistance are offered to the graduates?

(g) What are the local conditions that influence the job market for program graduates?

(h) What types of instructors are used by the program?

(i) What is each program's relationship to other area organizations (industry, union, and training)?

(j) What general types of problems have the programs encountered, and how have they responded to them?

(2) Graduate Characteristics and Labor Market Ex̄̄ẹeriènces

(a) What are the demographic and educational characteristics of graduates from the California CETA solar training programs?

(b) Why did they sign up for the training program?

(c) What were their employment skills and experiences before the solar training program?

(d) Have the graduates found jobs in the solar energy industry? If yes, what types of jobs are they filling and do they see their training as adequate? If no, what factors do they see as restricting their job opportunities?

(e) What types of solar systems have the graduates worked on since leaving the program?

(f) How satisfied are graduates with the amount and type of training they received?

(g) What kinds of interaction with unions have the graduates had?

\subsection{DATA COLLECTION AND ANALYSIS PROCEDURES}

In June 1979, SERI staff met with personnel from the CETA solar training programs to obtain background infor mation on each program. A common interview guide was used to collect this information. (The program questionnaire is included in Appendix B.) From this information, program descriptions were drafted and returned to the programs for comment and modification. These program descriptions are provided in Appendix D of this report. 
To collect information on the labor market experiences of the CETA program participants, SERI staff constructed a participant interview guide (Appendix B). Both interview guides were reviewed by the SERI Survey Review Committee and staff from the SolarCal Office and Calif ornia Employment Development Department. The draft guides were also distributed to solar training program personnel for review and comment.

Under subcontract to SERI, the SolarCal Office identified and located program participants. Between June and September 1979, SolarCal staff conducted personal interviews with 152 participants. Eight of the interviews could not be used because of missing answers or because the student had been in the program before the solar energy component was offered. The remaining 144 interviews were used for the analysis. The number of interviews and approximate number of program participants, as of June 1979 , for each program are shown in Table 2-1. Of approximately 450 participants, 144 interviews were conducted (a 32\% sample). The range of interviews per program as a percentage of total program participants is $16 \%-100 \%$. The highest percentages are related to relatively small programs. Among the larger programs, there appears to be some bias in the sample, with Sonoma (68\%) and Proteus (65\%) relatively overrepresented and Lakeview (16\%) and Westside CDC (24\%) underrepresented. This bias is the result of pragmatic factors, such as ease in locating graduates and geographic proximity to Sacramento, rather than purposeful selection of particular programs.

Table 2-1. PARTICIPANTS AND INTERVIEWS BY PROGRAM

\begin{tabular}{lcccc}
\hline \multicolumn{1}{c}{ Program } & No. of Graduates & No. of Interviews & $\begin{array}{c}\text { Interviews as } \% \\
\text { of Graduates }\end{array}$ & $\begin{array}{c}\text { \% of Total } \\
\text { Interviews }\end{array}$ \\
\hline Net Energyb & 4 & 3 & 75.0 & 2.1 \\
Proteus & 20 & 13 & 65.0 & 9.0 \\
Lakeview & 70 & 11 & 15.7 & 7.6 \\
Westside CDC & 250 & 61 & 24.4 & 42.4 \\
Sky Ray & 45 & 16 & 35.5 & 11.1 \\
Santa Clara & 1 & 1 & 100.0 & 0.7 \\
$\quad$ Adv. Trng. Center & 44 & 30 & 68.2 & 20.8 \\
Sonoma & 20 & 9 & 45.0 & 6.3 \\
Sacramento/Yolo & 454 & $144^{c}$ & 31.7 & 100.0 \\
Total & 4 & & & \\
\hline
\end{tabular}

${ }^{a}$ Approximate number of total program graduates, as of August 1979.

${ }$ These graduates were from an earlier training cycle than is described in the appendix.

${ }^{C}$ Of the 144 interviewees, 126 graduated from the program; the remaining 18 left the program before completing it.

Information from the participant/graduate interviews was computer-coded by SERI staff and analyzed using the Statistical Packages for the Social Sciences (SPSS). Frequency distributions and summary statistics for the major variables were calculated for the total sample. Standard statistical analyses (e.g., cross tabulations, correlations) were conducted to identify possible relationships among important variables (e.g.; factors affecting placement and post-program wage rates). 
SEPI 
SECTION 3.0

\section{THE CALIFORNIA CETA SOLAR TRANING PROGRAMS}

\subsection{INTRODUCTION AND HISTORY OF THE CALIFORNIA CETA SOLAR TRAINING EFRORT}

The use of California CETA funds to provide training for solar energy jobs began in 1976, when three programs were initiated (Sacramento-Yolo, Sonoma State, and Westside CDC). California's Office of Appropriate Technology, in cooperation with the Office of the State Architect, developed and implemented a pilot training program in Sacramento and Yolo Counties to test the feasibility of training CETA-eligible individuals for jobs in the solar energy industry. The 12-month program was offered only once (October 1976 to September 1977) and had 19 participants. Practical experience was combined with demonstrations of solar systems by retrofitting state-owned buildings with solar water heating systems.

As a result of this pilot program and other training efforts, increased state activity in solar energy, and federal programs to support CETA solar training, a number of other programs were developed and funded. At the time this study was initiated (spring of 1979), 12 CETA solar training programs were operating, or had operated, in California.* By December 1979, these programs had graduated slightly more than 500 individuals. The students have been trained for a variety of jobs in the solar industry-manufacturing, installation, maintenance, design, and sizing.

The programs vary widely in their design. Some evolved from other CETA efforts, such as weatherization; others are the first and only offering of a training organization. Some programs involve up to a year of college credit; others offer only on-the-job training (OJT) experience. Some programs include a specialized staff and well-equipped workshops; others use unpaid volunteers and a minimum of shop equipment.

This section summarizes the overall California CETA training effort and reviews program implications-the "lessons" learned by the directors of the programs. More detailed descriptions of each program are contained in Appendix E.

\subsection{DESCRIPTION OP PROGRAMS}

The California CETA solar training programs varied widely according to location and specific characteristics. Locations of the programs are shown in Fig. 3-1. Summaries of the programs' histories and slulus are provided in Table 3-1. In Table 3-2, general characteristics of the training programs are summarized. These tables are based on the detailed, narrative descriptions of the programs in Appendix E.

In most cases, the California CETA solar training programs were experimental. Many of them have been modified with experience; some were terminated before learning from early cycles could be incorporated into them. However, all were designed to meet the

*Three programs have since been terminated. 


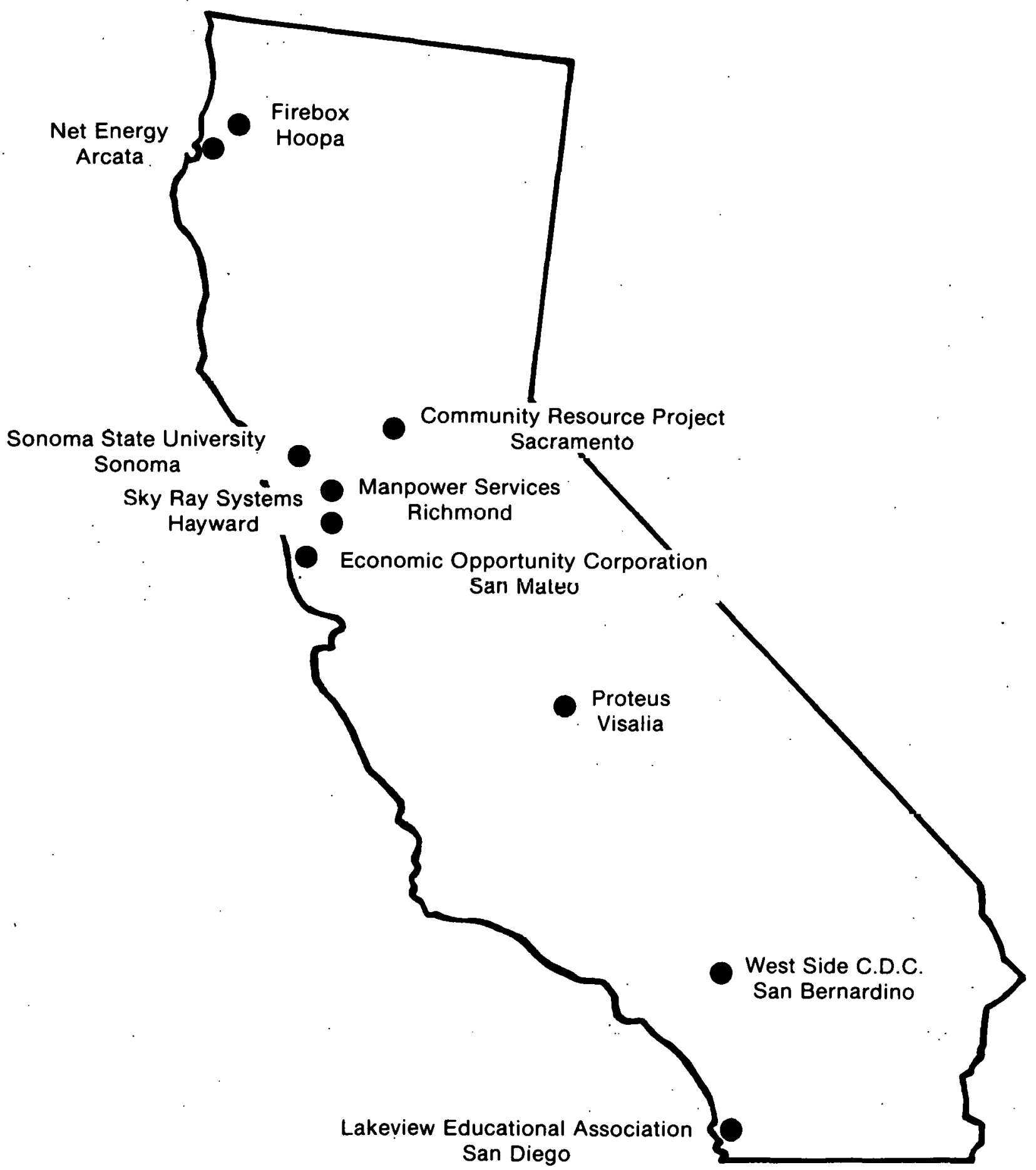

Figure 3-1. Program Locations.

Note: Two of the 12 program locations are not shown here. Sacramento-Yolo was a pilot project terminated after one year and was not operating at the time of the study. Santa Clara was a very small program consisting of on-the-job training with local solar contractors. 
needs of the local environment and program participants. For these reasons, the following discussion describes variations and ranges of basic program components and does not attempt to develop a recommended program design. The information used in this section was obtained primarily from interviews and meetings with program staff members.

\subsubsection{Program Objectives}

The primary objective of the solar training programs was to train CETA-eligible individuals for entry into the emerging solar industry in California. Relative emphasis in training varied among the programs, and generally included solar installation, manufacturing, theory, and design. Most of the programs also provided instruction in allied construction skills. An integral part of the training was motivating and preparing the historically hard-core unemployed to obtain and retain gainful employment through instruction in job behavior, work ethics, and career development.

Actual installations on low-income housing afforded programs the opportunity to fulfill another goal-to assist in a community's economic and educational development. By showing the public working solar systems, the programs hoped to increase community awareness of solar energy and energy-saving techniques. Some programs were involved in demonstrating the feasibility of solar technologies by gathering performance data and establishing information on cost-effective systems. Because of the newness of both the solar industry and the solar training programs, another objective was to test the practicality of solar job training for CETA-eligibles.

\subsubsection{Funding Levels and Sources}

All programs included in this study received some portion of their support from CETA funds. This included CETA prime sponsor funds, the Governor's $4 \%$ discretionary CETA funds, and the federal DOE/DOL/CSA SUEDE program.* Other funding sources were of ten used for the materials and components required for solar installations. These sources included the U.S. Department of Housing and Urban Development (HUD), the Bureau of Indian Affairs (BIA), the National Center for Appropriate Technology (NCAT), the Community Services Administration (CSA), DOE, and private companies.

The total cost per student for these solar training programs ranged from roughly $\$ 2,000$ to $\$ 9,500$. Cost differences depended on a number of factors, including costs of shop equipment, length of the training program, type of student, and type of training. If the upper end of the cost range seems high, it should be kept in mind that this figure includes all program costs (e.g., instructors, overhead, administration) except materials and components for permanent solar installations. Also, this range is not an accurate indication of the stipends paid to the students; those are largely determined by CETA regulations and procedures, and constitute only a portion of the total cost per student.

*The U.S. Department of Energy, U.S. Department of Labor, and Community Services Administration jointly sponsored the Solar Utilization, Economic Development and Employment (SUEDE) program during FY 1979. 
Table 3-1. SUMMARY OF CALIPORNIA CETA SOLAR TRAINING PROGRAMS

\begin{tabular}{|c|c|c|c|c|c|c|}
\hline $\begin{array}{l}\text { Name and Location of } \\
\text { Program }^{2}\end{array}$ & $\begin{array}{l}\text { Funding } \\
\text { Soüree }\end{array}$ & $\begin{array}{l}\text { Sponscring } \\
\text { Organization }\end{array}$ & $\begin{array}{l}\text { Date Program } \\
\text { Started }\end{array}$ & $\begin{array}{l}\text { Length of } \\
\text { Training } \\
\text { Program }\end{array}$ & $\begin{array}{l}\text { Number of } \\
\text { Graduates } \\
\text { as of } 12 / 1 / 79\end{array}$ & $\begin{array}{l}\text { Current } \\
\text { Status }\end{array}$ \\
\hline $\begin{array}{l}\text { The Firebox Solar } \\
\text { Water Heating Program } \\
\text { Fir-Tower House } \\
\text { Weitchpec Route } \\
\text { Hoopa Post Office } \\
\text { Hoopa, CA } 95546\end{array}$ & $\begin{array}{c}\text { CETA, } \\
\text { BIA }\end{array}$ & $\begin{array}{l}\text { Klamath River } \\
\text { Citizen Council }\end{array}$ & December : 978 & 18 months & 0 & Active \\
\hline $\begin{array}{l}\text { Solar Technician Training } \\
\text { Program, Net Energy } \\
854 \text { Ninth Street } \\
\text { Arcata, CA } 95521\end{array}$ & $\begin{array}{l}\text { CETA DOL/DOE } \\
\text { (SUEDE) }\end{array}$ & Humboldt County & Merch 1979 & c months & 14 & $\begin{array}{c}\text { Terminated } \\
\text { December } 1979\end{array}$ \\
\hline $\begin{array}{l}\text { Solar Demonstration } \\
\text { Project } \\
\text { Lakeview Educational } \\
\text { Association } \\
\text { 833 W. Fir Street } \\
\text { San Diego, CA 92101 }\end{array}$ & CETA & $\begin{array}{c}\text { San Diego Regional } \\
\text { Employment Training } \\
\text { Consortium }\end{array}$ & $\begin{array}{c}\text { January } 1379 \\
\cdot\end{array}$ & 15 weeks & 41 & $\begin{array}{c}\text { Terminated } \\
\text { September } 1979\end{array}$ \\
\hline $\begin{array}{l}\text { Solar/Energy Technician } \\
\text { Training .Program } \\
\text { Sonoma State University } \\
\text { 1801 E. Cotati } \\
\text { Rohnert Park, CA } 94928\end{array}$ & $\begin{array}{l}\text { First year, Gov. } \\
\text { discretionary; } \\
\text { second year, CETA }\end{array}$ & Sonoma Sounty & September 1976 & months & 47 & $\begin{array}{c}\text { Terminated } \\
\text { September } 1979\end{array}$ \\
\hline $\begin{array}{l}\text { Solar Training Program } \\
\text { Proteus Adult Training } \\
\text { P.O. Box } 727 \\
\text { Visalia, CA } 93279\end{array}$ & $\begin{array}{c}\text { Gov. } \\
\text { discretionary, } \\
\text { CSA, } \\
\text { CETA (Title II) }\end{array}$ & Se!f & Fébruary -978 & 5 months & 20 & Active \\
\hline
\end{tabular}

a This list does not include the Sacramento-Yolo Pilot Program or the Santa Clara OJT Program.

Includes on-the-job training (OJT). 
Table 3-1. SUMMARY OF CALIFORNIA CETA SOLAR TRAINING PROGRAMS (concluded)

\begin{tabular}{|c|c|c|c|c|c|c|}
\hline $\begin{array}{c}\text { Name and Location of } \\
\text { Program }^{8}\end{array}$ & $\begin{array}{l}\text { Funding } \\
\text { Source }\end{array}$ & $\begin{array}{l}\text { Sponsoring } \\
\text { Organization }\end{array}$ & $\begin{array}{l}\text { Date Program } \\
\text { Started }\end{array}$ & $\begin{array}{l}\text { Length of } \\
\text { Training } \\
\text { Program }\end{array}$ & $\begin{array}{c}\text { Number of } \\
\text { Graduates } \\
\text { as of } 12 / 1 / 79\end{array}$ & $\begin{array}{l}\text { Current } \\
\text { Status }\end{array}$ \\
\hline $\begin{array}{l}\text { Solar Energy Tecinnician } \\
\text {.Training Program } \\
\text { Manpower Services } \\
\text { City of Richmond } \\
33025 \text { th Street } \\
\text { Richmond, CA } 91804\end{array}$ & $\begin{array}{l}\text { DOL competitive } \\
\text { demonstration } \\
\text { grant (STIP) }\end{array}$ & City of Richmond & June 1979 & 18 months & 0 & Active \\
\hline $\begin{array}{l}\text { Solar Technician Training } \\
\text { Program } \\
\text { Sky Ray } \\
390 \text { Ocie Way } \\
\text { Hayward, CA } 94541\end{array}$ & CETA & $\begin{array}{c}\text { Alameda County } \\
\text { Training Employment } \\
\text { Board }\end{array}$ & August 1978 & 15 weeks & 45 & Active \\
\hline $\begin{array}{l}\text { Solar Energy Project } \\
\text { Economic Opportumity } \\
\text { Commission } \\
\text { Tap Route House } \\
1105 \text { Garden Street } \\
\text { E. Palo Alto, CA } 94033\end{array}$ & $\begin{array}{l}\text { CETA, } \\
\text { NCAT }\end{array}$ & County of San Mateo & January 1979 & 6 months & $5^{c}$ & Active \\
\hline $\begin{array}{l}\text { Solar Training and } \\
\text { Utilization } \\
\text { Community Resource Project } \\
3317 \text { S Street } \\
\text { Sacramento, CA } 95816 \text { : }\end{array}$ & CETA & $\begin{array}{l}\text { Sacramento Employ- } \\
\text { ment and Training } \\
\text { Agency (City and } \\
\text { County) }\end{array}$ & April 1979 & 9 months & 9 & Active \\
\hline $\begin{array}{l}\text { San Bernardino West Side } \\
\text { Community Development } \\
\text { Corporation } \\
1736 \text { W. Highland Ave. } \\
\text { San Bernardino, CA 92411 }\end{array}$ & $\begin{array}{l}\text { Multisource } \\
15 \text { sources) }\end{array}$ & $\begin{array}{l}\text { Inland Manpower } \\
\text { Association }\end{array}$ & 1976 & 6 months & 300 & Active \\
\hline
\end{tabular}

a This list does not include the Sacramento-Yolo Pilot Program or the Santa Clara OJT Program.

Includes on-the-job training (OJT).

cAs of July 1979. 
Table 3-2. CHARACTERISTICS OF TRAINING

\begin{tabular}{|c|c|c|c|c|c|c|}
\hline Program $^{\mathbf{a}}$ & Length & Hours/Week & Classroom & $\begin{array}{l}\text { Hands-on } \\
\text { Training }\end{array}$ & $\begin{array}{l}\text { On-the-Job } \\
\text { Training }\end{array}$ & $\begin{array}{l}\text { Number and Types of } \\
\text { Systems Installed } \\
\text { During the Program }\end{array}$ \\
\hline Firebox & 18 months & 20 & none & $\begin{array}{l}18 \text { months } \\
20 \text { hours per } \\
\text { week }\end{array}$ & & $\begin{array}{l}35 \text { installations: wood } \\
\text { stove water heating sys- } \\
\text { tems and solar water heat- } \\
\text { ing systems on Native } \\
\text { American homes }\end{array}$ \\
\hline Net Energy & 9 months & 30 & 3 months & $\begin{array}{l}3 \text { months of } \\
\text { workshops } \\
\text { included with } \\
\text { class sessions } \\
\text { and } 6 \text { months of } \\
\text { actual instal- } \\
\text { lations }\end{array}$ & & $\begin{array}{l}5 \text { bread-box water } \\
\text { heaters, } 1 \text { thermosiphon } \\
\text { water heater, } 4 \text { flat- } \\
\text { plate active water heaters, } \\
\text { and } 4 \text { attached greenhouse/ } \\
\text { solariums }\end{array}$ \\
\hline $\begin{array}{l}\text { Lakeview } \\
\text { Educational } \\
\text { Association }\end{array}$ & 15 weeks & 36 & 7 weeks & $\begin{array}{l}\text { Actual instal- } \\
\text { lations during } \\
\text { first } 7 \text { weeks } \\
\text { and } 8 \text { weeks of } \\
\text { OJT }\end{array}$ & $\begin{array}{l}40 \text { hours per } \\
\text { week; students } \\
\text { are paid the } \\
\text { normal wage } \\
\text { rate. LEA } \\
\text { reimburses the } \\
\text { em jloyer half } \\
\text { the wage rate } \\
\text { as sompensation } \\
\text { for training } \\
\text { the students. }\end{array}$ & $\begin{array}{l}1 \text { flat-plate domestic hot } \\
\text { water heater, } 1 \text { bread-box } \\
\text { water heater, } 2 \text { community } \\
\text { greenhouses, and } 1 \text { jacuzzi }\end{array}$ \\
\hline
\end{tabular}

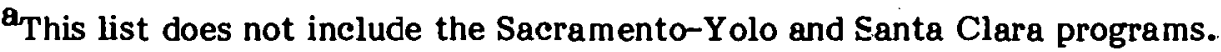


Table 3-2. CHARACTERISTICS OF TRAINING (continued)

\begin{tabular}{|c|c|c|c|c|c|c|}
\hline Program & Length & Hours/Week & Classroom & $\begin{array}{l}\text { Hands-on } \\
\text { Training }\end{array}$ & $\begin{array}{l}\text { On-the-Job } \\
\text { Training }\end{array}$ & $\begin{array}{l}\text { Number and Types of } \\
\text { Systems Installed } \\
\text { During the Program }\end{array}$ \\
\hline Sonoma & 9 months & 39 & $\begin{array}{l}11 \text { hours per } \\
\text { week }\end{array}$ & $\begin{array}{l}\text { Actual installa- } \\
\text { tions on Alter- } \\
\text { native Energy } \\
\text { Center building } \\
\text { and individual } \\
\text { projects } 8 \text { hours } \\
\text { per week }\end{array}$ & $\begin{array}{l}5 \text { hours per } \\
\text { week }\end{array}$ & $\begin{array}{l}\text { Constructed 600-sq.-ft. } \\
\text { Alternative Energy Center } \\
\text { demonstrating active and } \\
\text { passive solar system: } 2 \text { do- } \\
\text { mestic hot water systems } \\
\text { (1 active and l breadbox); } \\
3 \text { space heating systems, } \\
\text { which included l air system } \\
\text { and } 2 \text { water systems; and a } \\
\text { direct-gain space heating } \\
\text { system. Also constructed } \\
\text { detached greenhouse, and } \\
\text { numerous student projects }\end{array}$ \\
\hline
\end{tabular}

\begin{tabular}{|c|c|c|c|c|c|c|}
\hline Proteus & 5 months & 35 & $\begin{array}{l}\text { 10/hours per } \\
\text { week }\end{array}$ & $\begin{array}{l}\text { Workshops and } \\
\text { actual instal- } \\
\text { lations }\end{array}$ & $\begin{array}{l}\text { Optional ? } \\
\text { months OJT. } \\
\text { Proteus com- } \\
\text { pensates the } \\
\text { company 50\% } \\
\text { of trainee's } \\
\text { salary }\end{array}$ & $\begin{array}{l}28 \text { active domestic hot } \\
\text { water systems, } 37 \text { bread- } \\
\text { boxes, solar heating sys- } \\
\text { tem for swimming pool, } \\
\text { a hot water system for use } \\
\text { in the dairy at the local } \\
\text { community college, and a } \\
\text { greenhouse }\end{array}$ \\
\hline
\end{tabular}


Table 3-2. CHARACTERISTICS OF TRAINING (concluded)

\begin{tabular}{|c|c|c|c|c|c|c|}
\hline Program & Length & Hours/Week & Classroom & $\begin{array}{l}\text { Hands-on } \\
\text { Training }\end{array}$ & $\begin{array}{l}\text { On-the-Job } \\
\text { Training }\end{array}$ & $\begin{array}{l}\text { Number and Types of } \\
\text { Systems Installed } \\
\text { During the Program }\end{array}$ \\
\hline $\begin{array}{l}\text { Economic } \\
\text { Opportunity } \\
\text { Commission }\end{array}$ & 6 months & 40 & $\begin{array}{l}15 \text { tours per } \\
\text { week; } 8 \text { hours } \\
\text { of s upport } \\
\text { classes and } \\
2 \text { hcurs on } \\
\text { soler energy }\end{array}$ & $\begin{array}{l}25 \text { hours per } \\
\text { week actual } \\
\text { installation } \\
\text { and OJT }\end{array}$ & $\begin{array}{l}\text { Work } 10-12 \\
\text { hours per week, } \\
\text { including } \\
\text { weakends, with } \\
\text { private com- } \\
\text { panies primar- } \\
\text { ily installing } \\
\text { hot tubs and } \\
\text { sw:mming pool } \\
\text { applications }\end{array}$ & $\begin{array}{l}\text { Built a solar house, which } \\
\text { includes a domestic hot } \\
\text { water system and a green- } \\
\text { house }\end{array}$ \\
\hline $\begin{array}{l}\text { Community } \\
\text { Resource } \\
\text { Project } \\
\qquad\end{array}$ & 9 months & 40 & 6 months & $\begin{array}{l}\text { Workshops and } \\
\text { skills devel- } \\
\text { opment work } \\
\text { experience, ret- } \\
\text { rofit low in- } \\
\text { come housing }\end{array}$ & 3 nonths & $\begin{array}{l}\text { Built and installed } 4 \text { do- } \\
\text { mestic hot water systems, } \\
2 \text { greenhouses, and } 1 . \text { ac- } \\
\text { tive flat-plate system }\end{array}$ \\
\hline $\begin{array}{l}\text { Westside } \\
\text { CDC }\end{array}$ & 6 months & 40 & $\begin{array}{l}33 \% \text { of total } \\
\text { hours }\end{array}$ & $\begin{array}{l}33 \% \text { of total } \\
\text { hours in labo- } \\
\text { ratory work and } \\
33 \% \text { in actual } \\
\text { installations }\end{array}$ & & $\begin{array}{l}\text { Manufactured own solar } \\
\text { systems. Contracted in- } \\
\text { stallations and retrofits } \\
\text { with public housing proj- } \\
\text { ects; } 100 \text { bread-boxes and } \\
\text { flat-plate collectors, } 10 \\
\text { fan coil space-heating } \\
\text { systems, } 1 \text { greenhouse }\end{array}$ \\
\hline
\end{tabular}

systems, 1 greenhouse 


\subsubsection{Length and Intensity of Programs}

The training programs ranged in length from 15 weeks to 18 months, depending on the type and depth of training. Most of the programs involved 30 or more hours of combined classroom and hands-on training per week. Three of the programs (Westside CDC, Sacramento Community Resources Project, and San Mateo County EOC) trained their students with a 40-hour per week schedule. The only program with a training schedule of 20 hours or fewer per week was the Firebox program, which currently has no classroom training.

\subsubsection{General Characteristics of Training}

The programs were asked three general questions about their training: What portion of the course is spent on teaching general construction and trade skills compared with time spent on solar information and skills? How much time is spent teaching basic skills? What is the mix of classroom and OJT time?

Most of the programs spent $40 \%-60 \%$ of their time teaching basic construction or trades skills, and most or all of the remaining time on solar-specific skills. Two programs placed a heavier emphasis than the others on general skills. The San Diego program allocated two-thirds of its time to general skills; the Proteus program modified its course after the early cycles to allocate three-quarters of its time to general skills.*

Seven of the programs said they offered or planned to offer some training in basic job skills. The portion of course time devoted to this area ranged from $5 \%-20 \%$. Particular topics include career counseling, resume writing, job hunting skills, and general workrelated behavior such as regular attendance and promptness.

The portion of program time spent on workshops and OJT experience ranged from $20 \%-100 \%$, reflecting the different orientations of the programs. For example, the program at Sonoma State University focused on solar energy theory and system design and sizing, while the Firebox program was entirely an OJT program.

\subsubsection{Program Instructors}

The number of instructors for the training programs ranged from one full-time to eight part-time instructors. In the case of part-time instructors, the portion of their time actually used was not determined. Instructors included both paid individuals and volunteers. Some instructors also served as program directors or administrators, while others were members of local college or university faculties.

Instructors were selected for a number of skills and abilities. These included practical experience in construction skills or other industry trades, solar energy experience, competence and credibility in the topic area, teaching skills, communication and planning skills, and the ability to organize and coordinate the efforts of the students.

*The difference between general skills and solar-specific skills is not distinct in many cases, such as in the plumbing of a solar system. Thus, the programs may define similar components in different ways. 
In some cases, teaching responsibilities were divided among the program staff and other individuals. In the Sonoma program, the program director taught the solar courses while Sonoma State University faculty taught nonsolar support courses (e.g., mathematics and computer science). The San Diego, Net Energy, and Richmond programs supplemented their staff capabilities with visiting speakers and local community college faculty members.

\subsubsection{Advisory Boards}

At least five of the programs interviewed used an advisory board for their program. These boards ranged in size from three to eight members and included union and trade representatives, local solar industry businessmen, representatives from utility and power companies, architects, planners, educators, financiers, and graphic artists. The role of these boards differed among the programs, but generally focused on such functions as planning, providing feedback, and developing contacts with local businesses.

\subsubsection{Placement Procedures}

The programs used a number of methods to place their participants in jobs. In five of the programs, a job developer was on the staff. One program coordinated its efforts with the placement office at the local college. Contacts with local companies, particularly those providing OJT experiences, were considered part of the placement process. Students were also encouraged to participate actively in the placement effort. The programs provided training in job search and development, resume writing, and career counseling. Some programs focused on local placement while others (e.g., Sonoma) sought jobs nationwide for graduates.

\subsubsection{Tools and Manuals}

Except for the Firebox program, all of the programs provided tools and manuals for the students. In some cases, both hand tools and manuals became the students' property upon completion of the course. In other cases, some tools or the textbooks (but not both) were given to the graduates. The Sonoma course was unique in that the student was given a $\$ 200$ allowance to buy tools such as hand calculators.

\subsubsection{Certification and Credit}

Nine of the programs granted a certificate of some kind to graduates. In all cases but one, the certificate had no official standing outside of the program. The certificate granted by the San Bernardino program, however, has been accredited by the California Department of Private Post-secondary Education.

Three of the programs provided college credit for their graduates; one other program can give continuing education credit to graduates. A fif th program, Net Energy, intended to provide community college credits. However, delays in funding prevented the program from doing so. 


\subsection{FINDINGS FROM PROGRAM EXPERIENCES}

Interviews with program staff and discussions at the Sacramento conference identified some useful findings from program experiences. These can be grouped into three broad categories: (1) program components and considerations, (2) curriculum design and implementation, and (3) student selection and characteristics.

\subsubsection{Program Components and Considerations}

Four major aspects of the programs were singled out by the program staff as problem areas: (1) program costs and funding, (2) instructors' qualifications and availability, (3) staffing levels and characteristics, and (4) placement.

Funding concerns centered on the programs' sponsors' perception of solar training as an expensive program, and on the availability of financial support for installations. No calculations were available on training costs for other CETA programs of a similar nature, such as plumbing or carpentry courses.*

Solar energy systems that remain on the building on which they are installed cannot be funded with the CETA grants. Therefore, the programs used a variety of other funding sources for the systems, including HUD, CSA, BIA, and the building owners. Since many of the programs spent a large portion of their time on actual installations, this funding situation caused delays, limited the number of installations, and created additional (and of ten duplicative) administrative responsibilities.

The qualifications of solar instructors and their availability were important concerns for the program directors. In most cases, their ability to teach general construction and trades skills was most important, and solar experience and knowledge were next in importance. Other skills desired were general organizational abilities and communication skills. Program directors and administrators were, in many cases, also instructors for the courses.

Some program directors expressed concern that increasing solar training programs would exacerbate the shortage of qualified instructors. Because of the range of qualifications required and a shortage of individuals meeting those requirements and willing to teach in CETA programs, many programs have turned to consultants, visiting instructors, and faculty from local community colleges.

Staffing levels and characteristics were also of concern to the program directors. At the Sacramento meeting, they stated that a larger program staff was needed, that administrative functions should be separated from teaching functions, and that an appropriate staff/student ratio should be determined and applied to program planning. The amount of paperwork required by the CETA sponsors was large enough to require additional staff members whose time was not committed to teaching. In the meeting, one program

*Alan Hughes, the director of the San Diego program, said that the San Diego program had compared its costs with those of other local CETA programs and found them to be similar. Since the program had terminated and he had moved to the Bay Area, he no longer had access to actual figures. 
director stated that a minimum of five staff people would be needed for a group of 14-20 students, including an administrator or program director, a full-time teacher (or the equivalent in part-time employees), a supervisor for the workshop and field installations, a jọb developer, and a secretary.

Job placement was perhaps the primary program concern, in part because it was the major factor used by prime sponsors to evaluate the programs. Some programs felt pressured by their sponsors to achieve a high placement rate, regardless of whether the jobs wer'e in solar fields. Yet, the same sponsors also felt that the perceived high costs of solar training could be justified only by a high proportion of solar placements. This lack of clear placement goals has caused problems for both staff and students. Many of the latter expressed concern that they were being pressured into taking the first jobs offered, without a chance to look for a solar-related job.

A second part of the placement concern involved the trade-off between placements handled through a program job developer and improving the job development skills of the students so that they could play a major role in their own career development. Shortterm placement rates may improve with extensive "hand-holding," but the cost may be decreased ability of graduates to develop their own job-seeking skills.

\subsubsection{Curricula Design and Implementation}

The curricula developed and used by the programs varied widely in their scope and content.* As such, they provide a rich base for developing future programs. The variety of curricula generated a number of basic questions at the Sacramento meeting, including: How much can be taught in the CETA program time span? What should be the program balance between classroom and OJT time? What should be the balance between general construction or trades skills and specific solar skills and information? How standardized should a curriculum be? In what ways can the program develop basic job skills?

The amount of instruction (both scope and depth) that can be covered in the CETA programs depends in large part on the length and hours per week of the program. The programs ranged from 15 weeks to over a year long; most of them involved 30-40 hours per week.

Some of the programs chose to limit their instruction to one or more of the basic trades skills, such as plumbing, with only minor coverage of the solar topics. Other programs focused on specific solar skills and information, assuming that their trainees will be assisting journeymen on specific installations. Within the solar area, some programs focused on construction and installation of systems while others focused on system design and sizing.

All of the programs but one involved both classroom and OJT experience. Some programs integrated the OJT experience with classroom sessions; other programs completed the classroom sessions before beginning OJT or field installations. While the directors

*The California Office of Appropriate Technology (OAT) is sponsoring the development of a standard curriculum. Since it was not available at the time most of the programs were started, the programs developed their own. 
generally feit that practical experience was very important, they cautioned that it should not preclude the classroom work and that students should not be pressured to install too many systems during the training period. All of the programs included a mix of general skills and specific solar training. The directors felt that such a mix was necessary because of the small number of solar-specific jobs likely to be available in the next few years, the pressures from local employers to teach general skills, the mix of general and solar-specific skills. needed for actual installations, and the lack of related skills or experience in the background of many of the program participants.

The major arguments for a standardized curriculum are consistency in and control of training. While the program directors recognized the benefits of comparability across training programs, they also felt strongly that each program must be tailored to the local job market and to particular. types of participants. A compromise might be to develop a set of standardized modules that can be used in a variety of combinations. This general approach is being used by the California Office of Appropriate Technology in developing its curriculum.

One of the major purposes of the CETA programs was to provide participants with basic job skills. The solar programs provided this training in three major ways: specific classes and discussions on job behavior and job skills (such as how to find a job), designing the course for a 30-40 hour per week schedule to prepare students for actual work schedules, and obtaining OJT assignments that were as similar as possible to the types of jobs the graduates would be filling. In some programs, the OJT assignment became the person's first job after the training program, making the transition easy for the student.

\subsubsection{Student Selection and Characteristics}

Student-related factors of most concern to the program managers were (1) selection eriteria and processes and (2) student expectations.

To be accepted for the training programs, individuals had to be CETA-eligible. This designation includes, however, a wide range of educational and personal characteristics. A controversy existed over the use of aptitude tests rather than interviewer judgments in selecting students. The Sonoma program, because of its focus on design and estimation, screened applicants for 9th-grade math ability. In contrast, the San Bernardino program gave aptitude and education tests to students after they had been accepted into the program, using the test results for student guidance and training.

Program directors and prime sponsors were concerned that the early cycles of the CETA solar programs may have "skimmed" the best of the CETA-eligibles. The solar programs were perceived by some intake agencies as the top choice for training. Because of this, they may have directed the. more educated and motivated individuals toward solar programs. Program interviewers expressed concern that they were caught between conflicting pressures. On the one hand, pressures for a high placement rate encourages selection of more highly qualified and motivated applicants. Yet, this limits the programs' ability to serve a large portion of the CETA-eligible population.

In some cases, the programs were responsible for the selection process. In other cases, a local central intake unit handled the selection process for all area CETA programs. This can affect control over the general characteristics and mix of the students. It may also affect the type of information given to the applicant during the selection process. The program directors felt that CETA selection guidelines were unclear. 
One of the selection criteria, the skill levels of the participants, is noteworthy because of its importance to program directors. One facet of the problem was the desired level of particular skills. Programs focusing on design and estimating skills require a higher initial skill level in mathematics, while other programs may ask for experience in plumbing, carpentry, or machine operation. Program directors differ as to whether students all should be at about the same skill level or at various levels. The main argument for homogeneity is ease of planning and carrying out training, since the curriculum then can be the same for all students. The assignments during workshop sessions and OJT assignments can also be more similar and uniformly paced, as each student carries an equal share of the work load. Arguments for a mix of skill levels in the courses are that mixing does not "skim" the upper levels of CETA-eligibles, it is more similar to real-world job experiences, and it encourages students to help each other.

Student expectations for solar jobs were, in many cases, also a problem for the programs. If the applicants were selected by a central intake unit, the solar field could be "oversold." Four of the programs (Sonoma, Proteus, San Bernardino, and Sacramento) had meetings with applicants before or just after the selection process to discuss what to expect in solar jobs. Particular expectations that could create future difficulties were that the level of pay in solar jobs would be high (not the case in manufacturing and installation), that solar jobs would be more glamorous or exciting than traditional jobs, and that participants could be almost assured of getting a solar job. The program directors felt that such expectations were likely to cause students problems in the current solar job market. 


\section{SECTION 4.0}

\section{THE PROGRAM PARTICIPANTS}

\subsection{CHARACTERISTICS OP THE PARTCIPANT SAMPLE}

\subsubsection{Demographic Characteristics}

Slightly more than two-thirds of the student participants interviewed were male (102 males; 42 females). About half of the interviewees were whites (75); the rest were blacks (43), Hispanics (18), and other minority groups (Oriental and Native American) (8). Among individual programs, the minority participants as a percentage of total program interviewees ranged from $0 \%$ to $80 \%$. This range indicates that the CETA programs were quite varied in terms of the racial/ethnic distribution of their clientele. The ages of the graduates ranged from 18 to 53; most of the students were in the younger age groups. In Table 4-1, age ranges for the interviewees are shown. Three-quarters of the students (110) were not married, and about two-thirds (99) had no dependents other than themselves. Only 9 of the 144 had four or more dependents. In Table 4-2, data according to sex and ethnic background, by age are presented.

Table 4-1. AGES OF PARTICIPANTS

\begin{tabular}{lc}
\hline \multicolumn{1}{c}{ Age } & No. of Participants \\
\hline 18,19 & 8 \\
$20-24$ & 77 \\
$25-29$ & 37 \\
$30-34$ & 14 \\
$35-39$ & 4 \\
40 or older & 4 \\
\hline
\end{tabular}

About two-thirds of the students had been raised in urban or suburban areas (47 and 45 students, respectively). Forty-one had been raised in small towns and only 10 in rural areas.

\subsubsection{Bducation Backgrounds}

The students were, on the whole, relatively well educated. Only 14 of the 144 had not completed high school.* Seventy-seven had college experience; 19 received degrees. (This figure includes junior or community colleges as well as four-year colleges and universities.) The complete distribution of participants' formal education is shown in Table 4-3.

*Some of these high school graduates received their diploma or GED as part of the CETA program. 
Table 4-2. NUMBERS OF INTERVIEWEES BY AGE, SEX, AND ETHNIC BACKGROUND:

\begin{tabular}{|c|c|c|c|c|c|c|c|c|}
\hline \multirow{2}{*}{$\begin{array}{l}\text { Racial/ } \\
\text { Ethnic } \\
\text { Group. }\end{array}$} & \multirow[b]{2}{*}{ Sex } & \multicolumn{6}{|c|}{ Age } & \multirow[b]{2}{*}{ Total } \\
\hline & & 18,19 & $20-24$ & $25-29$ & $30-34$ & $35-39$ & 40 or older & \\
\hline White & $\begin{array}{l}\text { Male } \\
\text { Female }\end{array}$ & 1 & $\begin{array}{r}21 \\
6\end{array}$ & $\begin{array}{l}19 \\
12\end{array}$ & $\begin{array}{l}6 \\
4\end{array}$ & 3 & $\begin{array}{l}2 \\
1\end{array}$ & $\begin{array}{l}52 \\
23\end{array}$ \\
\hline Black & $\begin{array}{l}\text { Male } \\
\text { Female }\end{array}$ & $\begin{array}{l}6 \\
1\end{array}$ & $\begin{array}{l}22 \\
12\end{array}$ & 1 & & . & 1 & $\begin{array}{l}29 \\
14\end{array}$ \\
\hline Hispanic & $\begin{array}{l}\text { Male } \\
\text { Female }\end{array}$ & & $\begin{array}{r}10 \\
3\end{array}$ & 2 & 3 & . & & $\begin{array}{r}15 \\
3\end{array}$ \\
\hline $\begin{array}{l}\text { Other } \\
\text { (Oriental, } \\
\text { Nat. Amer.) }\end{array}$ & $\begin{array}{l}\text { Male } \\
\text { Female }\end{array}$ & & $\begin{array}{l}2 \\
1\end{array}$ & $\begin{array}{l}2 \\
1\end{array}$ & 1 & 1 . & & $\begin{array}{l}6 \\
2\end{array}$ \\
\hline Totals & & 8 & 77 & 37 & 14 & 4 & 4 & 144 \\
\hline $\begin{array}{l}\text { \% of } \\
\text { Participants }\end{array}$ & & 5.6 & 53.5 & 25.7 & 9.7 & 2.8 & 2.8 & 100 \\
\hline
\end{tabular}




\section{Table 4-3. EDUCATION LEVELS OF PROGRAM PARTICIPANTS}

\begin{tabular}{lc}
\hline Formal Education Level & No. of Participants \\
\hline Eighth grade & 1 \\
Some high school & 13 \\
High school graduate & 51 \\
Post-high school, noncollege & 2 \\
Some college & 58 \\
College degree & 19 \\
\hline \multicolumn{1}{c}{ Total } & 144 \\
\hline
\end{tabular}

Of those with college degrees, 19 received a bachelor's degree; 2 went on to earn a master's. The educational experiences that participants brought to the programs were varied, as shown by the topics studied by participants with some post-high school education (see Table 4-4).

More than half the students who had prior job training received it from former employers, on-the-job training, or the military. Sources of prior training are shown in Table 4-5.

Participants who had specific job-related training before enrolling in the CETA solar programs were asked to list the types of occupational training they had received. These responses are summarized in Table 4-6. As indicated by these data, the predominant types of occupational training participants previously had were those related to (1) professional, technical, and managerial and (2) structural jobs.

Over half the students had not participated in a CETA program before (86). Thirty-two of the students interviewed had participated in one or more CETA or similar programs.

\subsubsection{Employment Backgrounds}

The types of jobs participants held before enrolling in the CETA solar training programs are summarized in Table 4-7. It appears that the participants came from a variety of occupational backgrounds and had diverse job experiences. Three job categoriesstructural work; service; and professional, technical, and managerial-accounted for more than half of the total responses. Perhaps the most important finding is that most of the participants held several different types of jobs each. Of the 128 respondents, 76 (59\%) listed at least three previous occupations.

In Table 4-8, the participants' most recent jobs are listed. Service; professional, managerlal, and technical; and structural work again constitute the largest component of previous jobs. The relatively high proportion of professional, technical, and managerial occupations (15.1\%) is somewhat surprising for a sample of CETA-eligible individuals. Approximately $20 \%$ of the participants held jobs that would involve construction-type skills (machine trades, benchwork, and structural work). 
Table 4-4. FIELDS OF STUDY FOR GRADUATES WTH POST-HIGH SCHOOL EDUCATON

Education

5

Environmental Studies 5

Liberal Arts 15

Agriculture 2

Architecture 3

Trades

2

Business/Prof essional

6

Business/Clerical

Sciences 11

Social Sciences 5

Communications

Fine Arts

4

Solar and Alternative Energy

3

Electronics

4

Recreation

2

Multiple Nontechnical

1

Multiple Technical and Nontechnical

2 
Table 4-5. ' EMPLOYMENT TRAINING PRIOR TO THE CETA PROGRAMS

\begin{tabular}{lr}
\hline Courses provided by employer & $4^{\mathrm{a}}$ \\
On-the-job training & 21 \\
Trade or vocational-technical school & 10 \\
School & 2 \\
Military & 15 \\
Junior or community college & 1 \\
Apprenticeship & 4 \\
Other & 16 \\
None & 67 \\
\hline athese numbers will not total 144 because mul- \\
tiple responses were permitted and missing \\
responses are not shown.
\end{tabular}

Table 4-6. TYPES OF PREVIOUS TRANNING BY OCCUPATIONAL CATEGORY

\begin{tabular}{|c|c|c|c|c|}
\hline \multirow{2}{*}{ Job Category } & \multicolumn{2}{|c|}{ First Response } & \multicolumn{2}{|c|}{ Second Response } \\
\hline & No. & $\%$ & No. & $\%$ \\
\hline Professional, technical, and managerial & 10 & 25.6 & 6 & 33.3 \\
\hline Clerical & 4 & 10.3 & 1 & 5.5 \\
\hline Sales & - & - & - & - \\
\hline Service occupations & 4 & 10.3 & 1 & 5.6 \\
\hline Agricultural, fishing, and forestry & 1 & 2.6 & - & - \\
\hline Processing & - & - & 1 & 5.6 \\
\hline Machine trades & 2 & 5.1 & 2 & 11.1 \\
\hline Benchwork & 3 & 7.7 & - & - \\
\hline Structural work (nonsolar) & 14 & 35.9 & 7 & 38.9 \\
\hline Miscellaneous & 1 & 2.6 & - & - \\
\hline Total & $\overline{39}$ & $100.1^{\mathrm{a}}$ & $\overline{18}$ & 100.0 \\
\hline
\end{tabular}

${ }^{u}$ Column total does not equal $100 \%$ due to rounding. 
Table 4-7. TYPES OF JOBS PREVIOUSLY HELD

\begin{tabular}{lcr}
\hline \multicolumn{1}{c}{ Job Category $^{\mathrm{a}}$} & Number & \multicolumn{1}{c}{$\%$} \\
\hline Professional, technical, and managerial & 63 & 16.5 \\
Clerical & 25 & 6.5 \\
Sales & 20 & 5.2 \\
Service occupations & 63 & 16.5 \\
Agricultural, fishing, and forestry & 29 & 7.6 \\
Processing & 11 & 2.9 \\
Machine trades & 20 & 5.2 \\
Benchwork & 9 & 2.4 \\
Structural work & 79 & 20.7 \\
Miscellaneous & 39 & 10.2 \\
Unskilled (unspecified) & 17 & 4.5 \\
CETA or similar programs & 3 & 0.8 \\
Student & 1 & 0.3 \\
Uccupations In solar & 3 & 0.8 \\
(unspecified) & 3 & -100.1 \\
$\quad$ Total & $382^{\mathrm{b}}$ & 100. \\
\hline
\end{tabular}

a Job categories are defined in Appendix $D$.

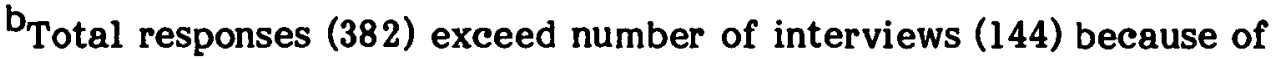
multiple answers. Responses are summarized as follows: No response: 16; one previous job: 21; two previous jobs: 31 ; three previous jobs: 32; four previous jobs: 23; five previous jobs: 10; and six previous jobs: 11 .

${ }^{\mathrm{C}}$ Column total does not equal $100 \%$ due to rounding. 
Table 4-8. MOST RECENT JOB HELD BEPORE SOLAR TRANING PROGRAM

\begin{tabular}{lrr}
\hline \multicolumn{1}{c}{ Job Category } & Number & $\%$ \\
\hline Professional, technical, and managerial & 21 & 15.1 \\
Clerical & 4 & 2.9 \\
Sales & 9 & 6.5 \\
Service occupations & 24 & 17.3 \\
Agricultural, fishing, and forestry & 10 & 7.2 \\
Processing & 2 & 1.4 \\
Machine trades & 5 & 3.6 \\
Benchwork & 3 & 2.2 \\
Structural work & 19 & 13.7 \\
Miscellaneous & 14 & 10.1 \\
Unskilled (unspecified) & 9 & 6.5 \\
CETA or similar programs & 9 & 6.5 \\
Student & 6 & 4.3 \\
Unemployed & 4 & 2.9 \\
\multicolumn{1}{c}{ Total } & 139 & $100.2 \mathrm{c}$ \\
\hline
\end{tabular}

a Job categories are defined in Appendix D.

bIt should be noted that the question asked was "What was your most recent job before the solar training program?" rather than if the respondent was unemployed. Since individuals must be unemployed or underemployed to be eligible for CETA programs, this percentage undoubtedly understates the extent of unemployed persons in the sample.

${ }^{c}$ Column total does not equal $100 \%$ due to rounding.

Table 4-9. NUMBER OF PREVIOUS EMPLOYBRS SINCE AGE 18

\begin{tabular}{lcrr}
\hline No. of Previous Employers & No. of Graduates & $\%$ & Cumulative \% \\
\hline 0 & 1 & 0.7 & 0.7 \\
$1-5$ & 79 & 55.2 & 55.9 \\
$6-10$ & 38 & 26.6 & 82.5 \\
$11-19$ & 13 & 9.1 & 91.6 \\
More than 20 & 8 & 5.6 & 97.2 \\
"Many" & 4 & 2.8 & 100.0 \\
Total & 143 & 100.0 & 100.0 \\
\hline
\end{tabular}


In Table 4-9, the number of program participants' previous employers since age 18 is summarized. The mean number of employers for the sample is 6.9. Since the average age of participants was slightly less than 25 years, this means that the average participant has had about one employer per year since age 18. These data indicate that the participants in the solar training programs exhibited employment histories that are probably typical of CETA-eligibles-frequent job changes and relatively short tenure in each job. This generalization is supported by the variety of types of jobs held since age 18 (Table 4-10); almost 50\% of the participants responded that they had performed "several" or "many" different kinds of work.

\subsection{PARTICIPANTS' EXPERIENCE WITH PROGRAMS}

\subsubsection{Reasons for Participating in the CETA Solar Programs}

The participants found out about the solar programs from a variety of sources. Fortyfive of them learned about the program through relatives or friends; 22 through media sources (television, newspapers, posted bulletins); and 5 by word-of-mouth. Informal and formal CETA information channels were of ten used. Eighteen of the students were referred by other CETA programs, while 52 were informed through people involved in the program or through the program itself. Only one graduate claimed to have found out about the program through personal research on and interest in solar energy:

Participants' reasons for signing up for the program were varied. Some had an interest in solar energy, others were more concerned with getting a job or developing more marketable skills. The number of students identifying various reasons for participating is shown in Table 4-11.

\subsubsection{Graduation from the CETA Programs}

Of the 144 participants interviewed, 126 (88\%) completed the CETA training programs: The remaining 18 (12\%) dropped out before graduation.

\subsubsection{Satisfaction with the Program}

The majority of the graduates were satisfied or very satisfied with the programs (see Table 4-12). They did, however, point out a number of problems which they suggested should be solved for future cycles of the course. These suggestions ranged from changes in the course content and equipment to interpersonal considerations. The suggestions most often made were that the programs involve less bureaucratic problems and red tape (14 graduates); more hands-on experience (17) and more on-the-job or field experience (11); a longer training period (11); and better job placement (10).

Somewhat less frequently mentioned suggestions were a need for more in-depth or specific training (8), more individual attention (8), and better organization or administration (8). 
Table 4-10. DIPFBRENT KINDS OF WORK SINCE AGE 18

\begin{tabular}{ccrc}
\hline Kinds of Work & No. of Graduates & $\%$ & Cumulative \% \\
\hline One & 6 & 4.2 & 4.2 \\
A few & 66 & 46.5 & 50.7 \\
Several & 38 & 26.8 & 77.5 \\
Many & 32 & 22.5 & 100.0 \\
Total & $\mathbb{1 4 2}$ & 100.0 & $\frac{100.0}{142}$ \\
\hline
\end{tabular}

Table 4-11. PARTICIPANTS' REASONS FOR SIGNING UP FOR PROGRAM

\begin{tabular}{lc}
\multicolumn{1}{c}{ Reasons } & No. of Students $^{\mathbf{a}}$ \\
\hline Needed a job or more money & 37 \\
Desired more marketable skills & 24 \\
Interest in solar and solar work & 57 \\
Get into the trades & 2 \\
Was required to sign up & 2 \\
General interest/something new & 8 \\
Looked like a good opportunity & 23 \\
Interest in solar design and & 5 \\
solar technologies & 3 \\
Curious & 1 \\
Employer wantcd solar slcills & \\
\hline
\end{tabular}

$a_{\text {Total exceeds }} 144$ because of multiple responses. 
Table 4-12. PARTICIPANTS' SATISFACTION WITH PROGRAM ${ }^{2}$

\begin{tabular}{|c|c|c|c|c|c|}
\hline & $\begin{array}{c}\text { Very } \\
\text { Dissatisfied }\end{array}$ & Dissatisfied & $\begin{array}{l}\text { Car:'t Decide, } \\
\text { Dic Not Know, } \\
\text { or No Response }\end{array}$ & Satisfied & $\begin{array}{l}\text { Very } \\
\text { Satisfied }\end{array}$ \\
\hline $\begin{array}{l}\text { Feedback from trainers about } \\
\text { performance }\end{array}$ & $0 . \because \%$ & $6.3 \%$ & $9.7 \%$ & $59.0 \%$ & $24.3 \%$ \\
\hline $\begin{array}{l}\text { Work assignments for } \\
\text { workshop sessions }\end{array}$ & 4.2 & 14.6 & 9.7 & 56.3 & 15.3 \\
\hline Time with instructors & 2.8 & 12.5 & 4.7 & 62.5 & 17.4 \\
\hline Handling of job placements & 9.0 & 16.0 & 13.2 & 36.1 & 25.7 \\
\hline Tools provided & 1.4 & 8.3 & 6.3 & 59.7 & 24.3 \\
\hline Manuals provided & $0 . \pi$ & 7.6 & 19.4 & 50.0 & 22.2 \\
\hline $\begin{array}{l}\text { Way tools and manuals } \\
\text { were provided }\end{array}$ & 0.7 & 4.2 & 5.6 & 74.3 & 15.3 \\
\hline $\begin{array}{l}\text { Program administration } \\
\text { in general }\end{array}$ & 9.0 & 16.0 & 13.9 & 40.3 & 20.8 \\
\hline
\end{tabular}

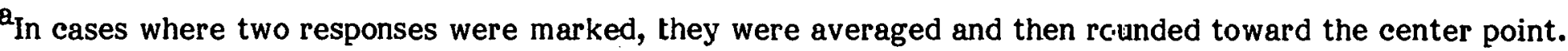




\subsubsection{Job Experience and the Training Program}

Participants were asked two specific questions that attempted to relate their experiences in the labor market to the solar training program. The first was, "Did the training program help in finding your first (post-program) job?" Of the 125 who answered this question, $86(68.8 \%)$ responded "yes," while $39(31.2 \%)$ responded "no."

The second question was, "Do you feel that the training program adequately prepared you for the work you are doing?" Responses to this question are summarized in Table 4-13. The majority of the participants (57.1\%) felt that the programs provided adequate training, while about $23 \%$ believed the training was inadequate for the jobs they found.

Table 4-13. DID THE TRAINING PROGRAM ADEQUATELY PREPARE YOU FOR CURRENT WORK?

\begin{tabular}{lrr}
\hline Response & No. & $\%$ \\
\hline Yes & 80 & 57.1 \\
No & 32 & 22.9 \\
Basic skills, not solar & 5 & 3.6 \\
Job behavior, not skills & 2 & 1.4 \\
Solar, not basic skills & 4 & 2.9 \\
Opened opportunity, not skills & 2 & 1.4 \\
Mixed answer (leans to yes) & 8 & 5.7 \\
Mixed answer (leans to no) & 1 & 0.7 \\
Uncertain & 6 & 4.3 \\
\multicolumn{1}{c}{$\quad$ Total } & 140 & 100.0 \\
\hline
\end{tabular}

\subsection{PLACEMENT AND JOB EXPERIENCES}

\subsubsection{Length of Time Since Leaving Program}

About half the participants had been out of the program only a year or less when pastgraduate job experiences were assessed (see Table 4-14). Many of the interviewees were very recent graduates; this makes it difficult to determine the long-term employment patterns of CETA solar trainees.

In order to get information on the types of jobs that graduates from the CETA programs obtained, several questions were asked about participants' post-program labor market experiences. In this section, data collected on jobs held by CETA graduates are summarized.

\subsubsection{Type of Job (Post-Program)}

The types of jobs-in terms of occupational category-found by participants after leaving the CETA programs are presented in Tuble 4-15. Definitions of the various categories are contained in Appendix D. Professional, technical, and managerial jobs and structural 
Table 4-14. LENGTH OF TIME SINCE GRADUATION

\begin{tabular}{cc}
\hline $\begin{array}{c}\text { No. of Quarters } \\
\text { Since Graduation }\end{array}$ & No. of Graduates \\
\hline 1 & 22 \\
2 & 16 \\
3 & 18 \\
4 & 14 \\
5 & 20 \\
6 & 5 \\
$7-9$ & 11 \\
$10-15$ & 23 \\
$20-25$ & 9 \\
\hline Six individuals did not indicate date of \\
graduation.
\end{tabular}


Table 4-15. TYPES OP JOBS HELD AFTER PROGRAM

\begin{tabular}{|c|c|c|c|c|c|c|c|c|c|c|c|c|}
\hline \multirow{2}{*}{ Job Category } & \multicolumn{2}{|c|}{ First Job } & \multicolumn{2}{|c|}{ Second Job } & \multicolumn{2}{|c|}{ Third Job } & \multicolumn{2}{|c|}{ Fourth Jcb } & \multicolumn{2}{|c|}{ Fif th Job } & \multicolumn{2}{|c|}{ Sixth Job } \\
\hline & No. & $\%$ & No. & $\%$ & No. & $\%$ & No. & 96 & No. & $\%$ & No. & $\%$ \\
\hline $\begin{array}{l}\text { Prof essional, } \\
\text { technical, End } \\
\text { managerial }\end{array}$ & 34 & 23.6 & 12 & 18.5 & 8 & 38.1 & 4 & 28.6 & 1 & 16.7 & - & - \\
\hline Clerical & 6 & 4.2 & 2 & 3.1 & - & - & 1 & 7.1 & - & - & - & - \\
\hline Sales & 2 & 1.4 & 2 & 3.1 & - & - & - & - & - & - & - & - \\
\hline Service occupations & 9 & 6.3 & 2 & 3.1 & 1 & 4.8 & - & - & 1 & 16.7 & - & - \\
\hline $\begin{array}{l}\text { Agricultural, fishery, } \\
\text { forestry, ard related } \\
\text { occupations }\end{array}$ & 4 & 2.8 & 1 & 1.5 & 1 & 4.8 & - & - & - & - & - & - \\
\hline Processing & 3 & 2.1 & - & - & - & - & - & - & - & - & - & - \\
\hline Machine trades & 7 & 4.9 & 4 & 6.2 & 1 & 4.8 & - & - & - & - & - & - \\
\hline Benchwork & 5 & 3.5 & 4 & 6.2 & 1 & 4.8 & - & - & 2 & 33.3 & - & - \\
\hline $\begin{array}{l}\text { Structural work } \\
\text { a. Nonsolar } \\
\text { b. Solar }\end{array}$ & $\begin{array}{r}51 \\
(20) \\
(31)\end{array}$ & $\begin{array}{l}35.4 \\
(13.9) \\
(21.5)\end{array}$ & $\begin{array}{r}22 \\
(11) \\
(11)\end{array}$ & $\begin{array}{l}33.9 \\
(16.9) \\
(16.9)\end{array}$ & $\begin{array}{c}6 \\
(4) \\
(2)\end{array}$ & $\begin{array}{r}28.6 \\
(19.1) \\
(9.5)\end{array}$ & $\begin{array}{r}7 \\
(4) \\
(3)\end{array}$ & $\begin{array}{l}50.0 \\
(28.6) \\
(21.4)\end{array}$ & $\begin{array}{c}2 \\
(2) \\
-\end{array}$ & $\begin{array}{c}33.3 \\
(33.3) \\
-\end{array}$ & $\stackrel{1}{(1)}$ & $\begin{array}{c}50.0 \\
(\mathbf{5 0 . 0}) \\
-\end{array}$ \\
\hline Miscellaneous & 4 & 2.8 & 2 & 3.1 & 1 & 4.8 & 1 & 7.1 & - & - & - & - \\
\hline Unskilled (unspecified) & 2 & 1.4 & - & - & - & - & - & - & - & - & - & - \\
\hline $\begin{array}{l}\text { CETA or simikar } \\
\text { programs }\end{array}$ & - & - & - & - & - & - & - & - & - & - & - & - \\
\hline Student & 5 & 3.5 & 1 & 1.5 & - & - & - & - & - & - & - & - \\
\hline \multicolumn{13}{|l|}{ Occupations in solar } \\
\hline (Not specifiきd) & - & - & - & - & - & - & - & - & - & - & - & - \\
\hline Unemployed $^{\mathrm{b}}$ & 12 & 8.3 & 13 & 20.0 & 2 & 9.5 & 1 & 7.1 & - & - & 1 & 50.0 \\
\hline TOTAL & 144 & & 65 & & 21 & & 14 & & 6 & & 2 & \\
\hline
\end{tabular}

Subtotal of structural work.

${ }^{b}$ At the time of the interview, 30 of the 144 participants (21\%) were unemployed. The unemployment rate was much higher for nongraduates $(39 \% ; 7$ of 18$)$ than for graduates $(18 \% ; 23$ of 126$)$. 
work occupations total almost $60 \%$ of first jobs found when the individuals left the programs. A significant proportion (21.5\%) of the respondents described their jobs as specifically involving solar energy (installation and assembly).* Employment after the initial placement also involved a significant number of solar-specific jobs, which may indicate that graduates were able to move into solar jobs after obtaining temporary employment in nonsolar areas. Eight percent of the participants (12 of 144) were unable to find jobs initially. At the time of the interview, 23 of the 126 (18\%) who graduated from the program were unemployed. For those who left the program before completion, 39\% (7 of 18) were unemployed at the time of the interview.

\subsubsection{Type of Business}

The types of businesses that participants worked for after they left the program are presented in Table 4-16. No single type of business predominates, although a large percentage (57\%) of the participants worked for contruction and manufacturing firms (solar and nonsolar) in their first jobs. The single business category given most frequently for first and second jobs was a construction firm related to solar energy.

\subsubsection{Wage Levels}

The initial and top (either current or wage at time the individual left the job) hourly wage rates for CETA program participants are presented in Tables 4-17 and 4-18. For first jobs after leaving the program, the average starting wage was $\$ 4.33 / \mathrm{hr}$, with a range from $\$ 1.90$ to $\$ 10.00 / \mathrm{hr}$. Wages at the end of the first job (either current wage at the time of the interview or wage when participant left the job) averaged $\$ 5.20 / \mathrm{hr}$, with a range from $\$ 2.35$ to $\$ 18.00 / \mathrm{hr}$. There is also some indication that individuals who left their initial jobs were able to find better-paying jobs (at least for the second, third, and fourth jobs). For example, starting salaries for second jobs averaged $\$ 1.27$ higher than those in the initial job ( $\$ 5.60$ versus $\$ 4.33 / \mathrm{hr}$ ), and the starting salaries for second jobs were higher than the average top wage in first fobs (\$3.60 versus \$5.20). In lel'uls uf hourly wage rates, it therefore appears that graduates of CETA solar training programs have been able to advance, both by working at the same job and by finding new ones. It is also important to note that more than $90 \%$ (103 of 114) of the participants were able to find employment paying more than the current federal minimum wage rate $(\$ 2.90 / \mathrm{hr})$ prevailing at the time of interview.

For individual programs, the lowest starting salary in the first job averaged $\$ 3.84 / \mathrm{hr}$, while the highest starting salary for any particular program averaged $\$ 6.37 / \mathrm{hr}$. Ending wage levels in the first job were similarly diverse; the lowest program average was $\$ 4.52 / \mathrm{hr}$ and the highest was $\$ 8.02 / \mathrm{hr}$. These ranges for individual programs again indicate wide diversity among program experiences and suggest caution in drawing broad inferences from aggregate statistics.

*Sixty percent of the graduates responded (Table 4-23) that their initial jobs involved some aspect of solar energy. The percentages of solar-related jobs listed in response to this question understates the actual number of graduates employed in the solar field, particularly in management, design, and sales. 
Table 4-16. TYPES OF BUSINESSES JOINED AFTER PROGRAM

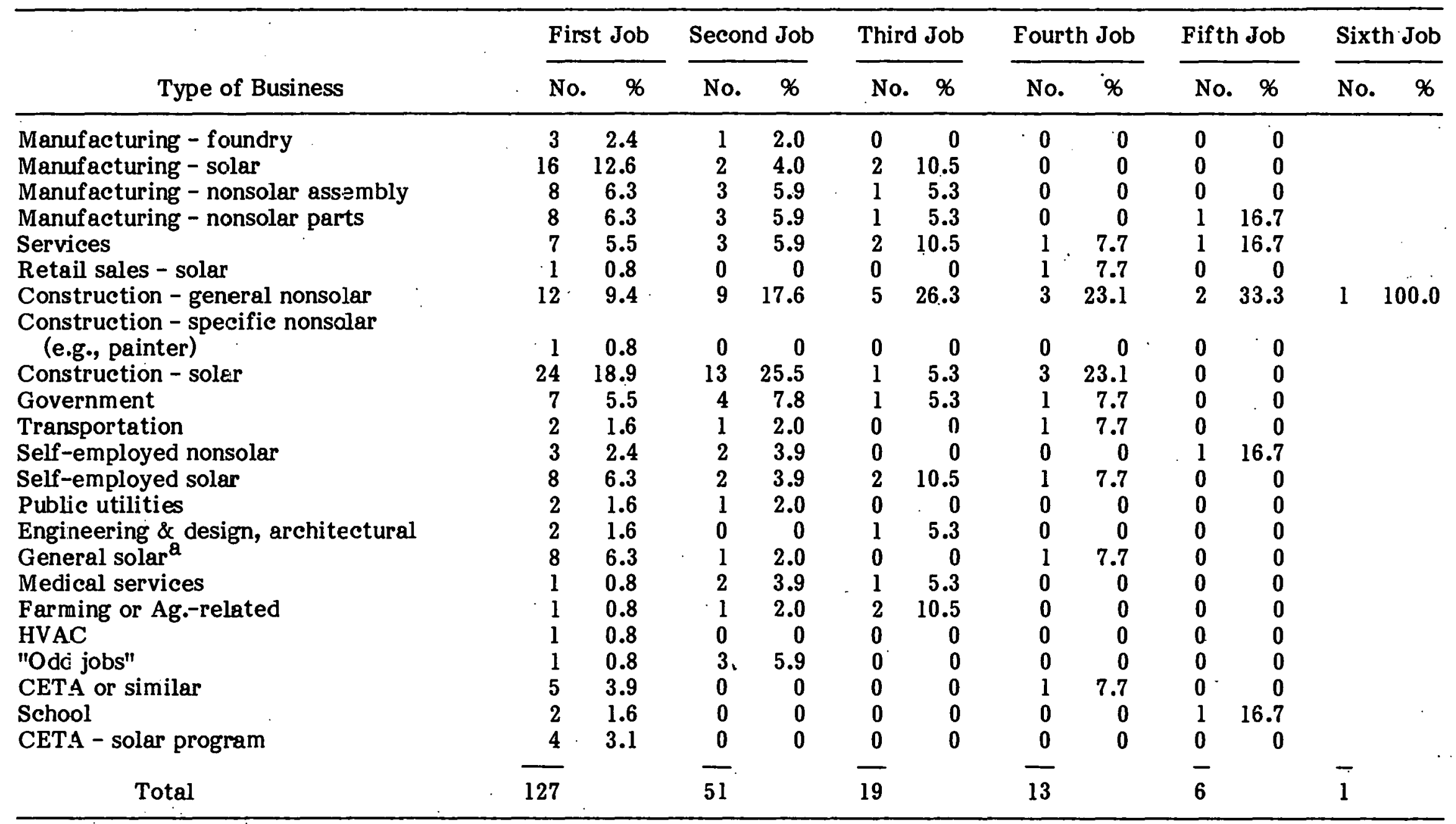

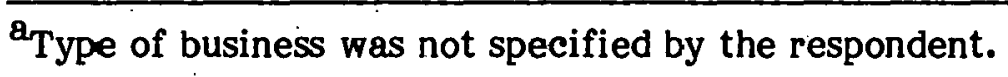


Table 4-17. INITIAL HOURLY WAGE RATES AFTER PROGRAM

\begin{tabular}{|c|c|c|c|c|c|c|c|c|c|c|c|c|}
\hline \multirow[b]{2}{*}{ Wage Rate (\$) } & \multicolumn{2}{|c|}{ First Job } & \multicolumn{2}{|c|}{ Second Job } & \multicolumn{2}{|c|}{ Third Job } & \multicolumn{2}{|c|}{ Fourth Job } & \multicolumn{2}{|c|}{ Fif th Job } & \multicolumn{2}{|c|}{ Sixth Job } \\
\hline & No. & $\%$ & No. & $\%$ & No. & $\%$ & No. & $\%$ & No. & $\%$ & No. & $\%$ \\
\hline $1.90-3.00$ & 19 & 16.7 & 4 & 9.5 & 2 & 11.1 & 0 & 0 & $\mathbf{0}$ & & $\mathbf{0}$ & \\
\hline $3.01-3.50$ & 23 & 20.2 & 3 & 7.1 & 3 & 16.7 & 3 & 27.3 & 1 & 20.0 & 1 & 100.0 \\
\hline $3.51-4.00$ & 22 & 19.3 & 5 & 11.9 & 1 & 5.6 & 0 & 0 & 1 & 20.0 & 0 & \\
\hline $4: 01-4.50$ & 12 & 10.5 & 5 & 11.9 & 2 & 11.1 & 2 & 18.2 & 2 & 40.0 & o & \\
\hline $4.51-5.00$ & 3 & 2.6 & 1 & 2.4 & 2 & 11.1 & 1 & 9.1 & 0 & & 0 & \\
\hline $5.01-5.50$ & 14 & 12.3 & 7 & 16.7 & 2 & 11.1 & 0 & 0 & 0 & & 0 & \\
\hline $5.51-6.50$ & 11 & 9.6 & 6 & 14.3 & 1 & 5.6 & 1 & 9.1 & 0 & & 0 & \\
\hline $6.51-7.50$ & 6 & 5.3 & 6 & 14.3 & 2 & 11.1 & 1 & 9.1 & 0 & & 0 & \\
\hline $7.51-8.50$ & 3 & 2.6 & 2 & 4.8 & 0 & 0 & 2 & 18.2 & 0 & & 0 & \\
\hline More than $\mathbf{8 . 5 0}$ & 1 & 0.9 & 3 & 7.1 & 3 & 16.7 & 1 & 9.1 & 1 & 20.0 & $\mathbf{0}$ & \\
\hline Total & 114 & 100.0 & 42 & 100.0 & 18 & 100.0 & 11 & 100.0 & 5 & 100.0 & 1 & 100.0 \\
\hline $\begin{array}{l}\text { Average hourly } \\
\text { wage }\end{array}$ & $\$ 4.33$ & & $\$ 5.60$ & & $\$ 6.3$ & & $\$ 6.0$ & & $\$ 5.5$ & & & 3.50 \\
\hline
\end{tabular}

Table 4-18. HIGHEST HOURLY WAGE RATES AFTER PROGRAM

\begin{tabular}{|c|c|c|c|c|c|c|c|c|c|c|c|c|}
\hline \multirow[b]{2}{*}{ Wage Rate (\$) } & \multicolumn{2}{|c|}{ First Job } & \multicolumn{2}{|c|}{ Sccond Job } & \multicolumn{2}{|c|}{ Third Job } & \multicolumn{2}{|c|}{ Fourth Job } & \multicolumn{2}{|c|}{ Fif th Jnb } & \multicolumn{2}{|c|}{ Sixth Inh } \\
\hline & No. & $\%$ & No. & $\%$ & No. & $\%$ & No. & $\%$ & No. & $\%$ & No. & $\%$ \\
\hline $1.90-3.00$ & 12 & 11.0 & 1 & 2.4 & 2 & 12.5 & 0 & 0 & $\mathbf{0}$ & 0 & 0 & $\mathbf{0}$ \\
\hline $3.01-3.50$ & 16 & 14.7 & 2 & 4.9 & 3 & 18.8 & 2 & 25.0 & 0 & 0 & 0 & $\mathbf{0}$ \\
\hline $3.51-4.00$ & 16 & 14.7 & 4 & 9.8 & $\mathbf{0}$ & o & $\mathbf{0}$ & o & 1 & 25.0 & 1 & 100.0 \\
\hline $4.01-4.50$ & 7 & 6.4 & 4 & 9.8 & 0 & 0 & 2 & 25.0 & 1 & 25.0 & 0 & 0 \\
\hline $4.51-5.00$ & 14 & 12.8 & 7 & 17.1 & 2 & 12.5 & $\mathbf{0}$ & 0 & 0 & 0 & 0 & $\mathbf{0}$ \\
\hline $5.01-5.50$ & 10 & 9.2 & 4 & 9.8 & $\mathbf{0}$ & 0 & $\mathbf{0}$ & $\mathbf{0}$ & 1 & 25.0 & $\mathbf{0}$ & 0 \\
\hline $5.51-6.50$ & 10 & 9.2 & 4 & 9.8 & 4 & 25.0 & 0 & 0 & 1 & 25.0 & 0 & 0 \\
\hline $6.51-7.50$ & 13 & 11.9 & 5 & 12.2 & 1 & 6.2 & 1 & 12.5 & 0 & o & $\mathbf{0}$ & $\mathbf{0}$ \\
\hline $7.51-8.50$ & 4 & 3.7 & 2 & 4.9 & 0 & 0 & 0 & 0 & $\mathbf{0}$ & $\mathbf{0}$ & $\mathbf{0}$ & 0 \\
\hline More than 8.50 & 7 & 6.4 & 8 & 19.5 & 4 & 25.0 & 3 & 37.5 & 0 & 0 & 0 & 0 \\
\hline Total & 109 & 100.0 & 41 & $100.2^{\mathrm{Q}}$ & 16 & 100.0 & 8 & 100.0 & 41 & 100.0 & 1 & 100.0 \\
\hline $\begin{array}{c}\text { Average hourly } \\
\text { wage }\end{array}$ & $\$ 5.20$ & & $\$ 6.50$ & & $\$ 6.6$ & & $\$ 6.48$ & & $\$ 4$ & & $\$ 4$ & \\
\hline
\end{tabular}

${ }^{a}$ Column total does not equal $100 \%$ due to rounding. 


\subsubsection{Hours Per Week Employed}

To provide some information about whether employment found by graduates was steady, participants were asked how many hours of work per week they averaged in their first job. As indicated in Table 4-19, most of the participants were able to find full-time work; $82(69 \%)$ responded that they were working 40 hours per week. Only 16 (13.4\%) said that they were working $\mathbf{3 0}$ or fewer hours per week.

\section{4:3.6 Length of Employment}

The average length of employment (in months) in jobs held by program graduates is summarized in Table 4-20. It should be noted that many of the respondents are recent graduates, which probably biases these averages downward. For first jobs, the average length of employment was 6.5 months; $49 \%$ were still at their first job at the time of the interview. Second jobs averaged 7 months, and $54 \%$ of those who took second jobs were still employed in that job.

\subsubsection{Reasons for Leaving Jobs}

As indicated by previous data on number of jobs held by program participants, a significant number of those interviewed left their initial jobs, and some had held four or more jobs at the time of the interview. To determine reasons for these job changes, participants were asked why they left their previous jobs (Table 4-21). The most frequent reasons given for leaving were that they found better jobs, the business or project was discontinued, or there were particular aspects of the job they did not like.

\subsubsection{Union and Nonunion Jobs}

One issue related to solar jobs is the role of union and nonunion labor. Trade unions are anxious to ensure solar employment for their members, while others view the solar industry as an opportunity to open fields of employment to nonunion individuals. As a result, trade unions have been less than enthusiastic about CETA-funded solar training efforts, except perhaps as preapprenticeship programs.

To provide some information on the experience of graduates of CETA solar training programs with trade unions, participants were asked about their contacts with unions. Of the 110 respondents, only $11(10 \%)$ stated that they had worked with union members on a job site.

Graduates were also asked, "Are you now in any way affiliated with a union?" Of the 143 responses, 21 (14.6\%) indicated they were affiliated with one or more unions. The union affiliations of those graduates are presented in Table 4-22.

\subsection{SOLAR BMPLOYMENT AND EXPERIENCE}

\subsubsection{Solar vs. Nonsolar Jobs}

Responses to the question, "Did (or does) your job involve solar energy?" are presented in Table 4-23. A majority (58\%) of the respondents indicated that the first job they 
obtained after leaving the program involved solar energy. However, among those who left their initial jobs, the relative proportion who found solar jobs declined. At the time of the interview, $44 \%$ of the participants (62 of 141) were employed in solar jobs. It should be noted that many of the respondents were very recent graduates from solar training programs, and much career "sorting out" had not yet occurred.

Within individual programs, all participants from two of the programs responded that their first job involved a solar energy component. The lowest placement rate in solar jobs registered by an individual program was $21 \%$.

In Table 4-24, the general type of first job found after leaving the program is crossreferenced with the question, "Does your job involve solar energy?" Almost $95 \%$ of those whose first job had a solar component listed their general job category as professional, technical, and managerial (45.1\%) or structural work (49.3\%). These statisties suggest that, among the graduates who obtained solar employment, the solar jobs were split about equally between designing and sizing (professional, technical, and managerial) and installing solar systems (structural).

\subsubsection{Percentage of Job Time on Solar}

In Table 4-25, the percentage of work time spent on solar energy activities for respondents who had solar-related jobs is summarized. About $80 \%$ of those whose first job had a solar component worked in solar energy full-time.

\subsubsection{Solar Installations Worked on by Participants}

Of the 144 graduates interviewed, 66 (45.8\%) indicated that they had worked on solar installations since leaving the program. The distribution of the number of installations worked on by these graduates is provided in Table 4-26. Most of the participants (39\%) who had. installed solar systems worked on 10 or fewer installations. Eighteen graduates had worked-on 11-100 installations. Seven individuals reported that they had worked on more than 100 systems.

In terms of types of solar systems installed by graduates, nearly all were some form of residential hot water systems (Table 4-27). Domestic hot water systems and pool and hot tub applications accounted for $86 \%$ of the solar installations. Although the majority of the graduates (64 of those who had installed solar systems) indicated that they worked primarily on single-family home installations, a significant number (45) had also installed solar systems on multifamily residences and commercial buildings.

\subsection{FACTORS AFFECTING PLACEMENT EXPERIENCE}

To provide some insight into the factors that may influence post-program job market experiences of participants; a descriptive analysis of relationships between participant characteristics (demographics, prior education) and placement data (type of job, solar versus nonsolar, wage rate) was conducted. Given the limited sample size and qualitative nature of the data, vigorous statistical testing of causality cannot be performed. Results from the analysis should therefore be interpreted only as indicative of general relationships and directions of influence rather than as precise statements of causality and magnitude. 
Table 4-19. HOURS PER WEEK

BMPLOYED, FIRST

JOB AFTBR PROGRAM

\begin{tabular}{lrr}
\hline Hours Per Week & No. & $\chi$ \\
\hline $8-20$ & $8^{\mathrm{a}}$ & 6.7 \\
$21-30$ & 8 & 6.7 \\
$31-40$ & 89 & 74.8 \\
$41-50$ & 9 & 7.6 \\
More than 50 & 5 & 4.2 \\
$\quad$ Total & $119^{\mathrm{a}}$ & 100.0
\end{tabular}

Average hours

per week

38.8

ancludes one respondent who listed two part-time jobs.

Table 4-20. LENGTH OF EMPLOYMENT, AFTER PROGRAM

\begin{tabular}{|c|c|c|c|c|c|c|c|c|c|c|c|c|}
\hline \multirow{2}{*}{$\begin{array}{l}\text { Length in Job } \\
\text { (months) }\end{array}$} & \multicolumn{2}{|c|}{ First Job } & \multicolumn{2}{|c|}{ Second Job } & \multicolumn{2}{|c|}{ Third Job } & \multicolumn{2}{|c|}{ Fourth Job } & \multicolumn{2}{|c|}{ Fif th Job } & \multicolumn{2}{|c|}{ Sixth Job } \\
\hline & No. & $\%$ & No. & $\%$ & No. & $\%$ & No. & $\%$ & No. & $\%$ & No. & $\%$ \\
\hline $\begin{array}{l}1 \text { or less } \\
2-6 \\
7-12 \\
13-24 \\
25-36\end{array}$ & $\begin{array}{r}24 \\
61 \\
21 \\
11 \\
4\end{array}$ & $\begin{array}{r}19.8 \\
50.4 \\
17.4 \\
9.1 \\
3.3\end{array}$ & $\begin{array}{r}15 \\
16 \\
6 \\
8 \\
1\end{array}$ & $\begin{array}{r}32.6 \\
34.8 \\
13.0 \\
17.4 \\
2.2\end{array}$ & $\begin{array}{l}3 \\
7 \\
5 \\
0 \\
0\end{array}$ & $\begin{array}{r}20.0 \\
46.7 \\
33.3 \\
0 \\
0\end{array}$ & $\begin{array}{l}4 \\
2 \\
2 \\
1 \\
1\end{array}$ & $\begin{array}{l}40.0 \\
20.0 \\
20.0 \\
10.0 \\
10.0\end{array}$ & $\begin{array}{l}1 \\
2 \\
2 \\
0 \\
0\end{array}$ & $\begin{array}{r}20.0 \\
40.0 \\
40.0 \\
0 \\
0\end{array}$ & $\begin{array}{l}0 \\
1 \\
0 \\
0 \\
0\end{array}$ & $\begin{array}{r}0 \\
100.0 \\
0 \\
0 \\
0\end{array}$ \\
\hline $\begin{array}{l}\text { Total } \\
\text { Average no. of } \\
\text { months in job }\end{array}$ & $\begin{array}{l}121 \\
6.5\end{array}$ & 100.0 & 7.0 & 100.0 & 4.8 & 100.0 & 9.5 & 100.0 & $\begin{array}{c}5 \\
5.0\end{array}$ & 100.0 & $\begin{array}{l}1 \\
2.0\end{array}$ & 100.0 \\
\hline $\begin{array}{l}\text { Still at this job a } \\
\text { time of intervi }\end{array}$ & & & & & & & & & & & & \\
\hline $\begin{array}{l}\text { Yes } \\
\text { No }\end{array}$ & $\begin{array}{l}61 \\
64\end{array}$ & $\begin{array}{l}48.8 \\
51.2\end{array}$ & $\begin{array}{l}26 \\
22\end{array}$ & $\begin{array}{l}54.2 \\
45.8\end{array}$ & $\begin{array}{r}6 \\
12\end{array}$ & $\begin{array}{l}33.3 \\
66.7\end{array}$ & $\begin{array}{l}9 \\
4\end{array}$ & $\begin{array}{l}69.2 \\
30.8\end{array}$ & $\begin{array}{l}4 \\
2\end{array}$ & $\begin{array}{l}66.7 \\
33.3\end{array}$ & - & \\
\hline
\end{tabular}


Table 4-21. RBASONS POR LEAVNG JOBS

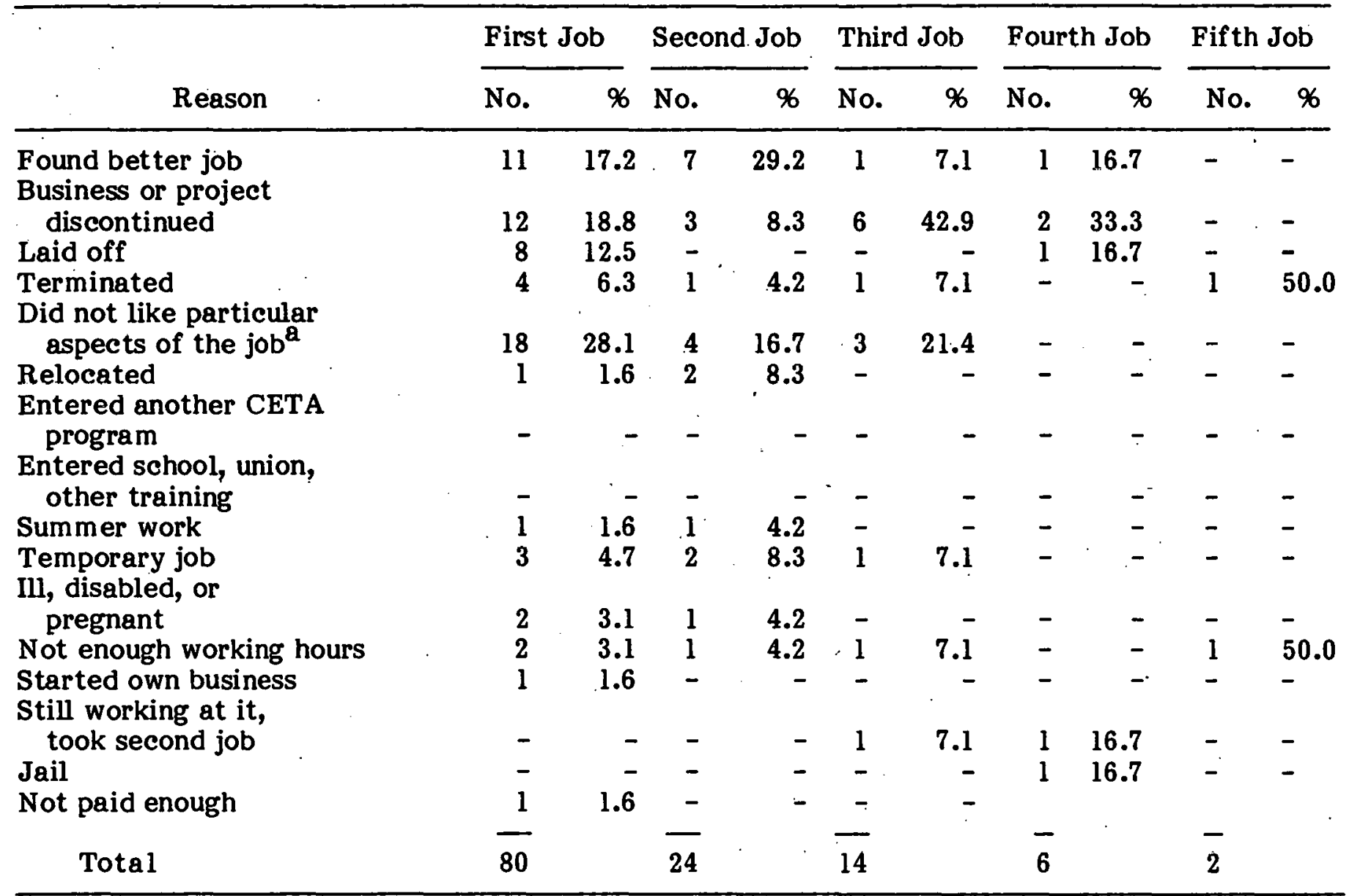

${ }^{a_{S}}$ uch as personality conflicts, distance between job and residence, career change, or did not offer job security. 
Table 4-22. UNION AFPIIATIONS OF GRADUATES

\begin{tabular}{lcr}
\hline \multicolumn{1}{c}{ Union } & No. of Graduates & $\%$ \\
\hline Railway Carmen's Union & 2 & 8.7 \\
Teamsters & 1 & 4.3 \\
United Furniture Workers & 1 & 4.3 \\
United Steelworkers & 3 & 13.0 \\
United Industrial Union, AFL-CIO & 1 & 4.3 \\
Carpenter's Union & 1 & 4.3 \\
Plumbers and Steampipe Fitters & 3 & 13.0 \\
Teachers Union, AFL-CIO & 1 & 4.3 \\
Civil Service Employees Assn. & 1 & 4.3 \\
Glaziers & 1 & 4.3 \\
Millwright and Machinery & 1 & 4.3 \\
Rohr Aircraft Union & 3 & 13.0 \\
Cement and Masons & 1 & 4.3 \\
Not specified & 3 & 13.0 \\
\hline \multicolumn{1}{c}{ Total } & $23^{\mathrm{a}}$ & $99.4^{\mathrm{b}}$
\end{tabular}

${ }^{a}$ Includes multiple answers for those who have belonged to more than one union.

${ }^{b}$ Column total does not equal $100 \%$ due to rounding.

Table 4-23. DID POST-PROGRAM JOB INVOLVE SOLAR ENERGY?

\begin{tabular}{|c|c|c|c|c|c|c|c|c|c|c|c|c|}
\hline & \multicolumn{2}{|c|}{ First Job } & \multicolumn{2}{|c|}{ Second Job } & \multicolumn{2}{|c|}{ Third Job } & \multicolumn{2}{|c|}{ Fourth Job } & \multicolumn{2}{|c|}{ Fif th Job } & \multicolumn{2}{|c|}{ Sixth Job } \\
\hline & No. & 96 & No. & 96 & No. & \% & No. & & No. & $\mathscr{B}$ & Nú. & 96 \\
\hline $\begin{array}{l}\text { Yes } \\
\text { No }\end{array}$ & $\begin{array}{l}71^{a} \\
52\end{array}$ & $\begin{array}{l}57.7 \\
42.3\end{array}$ & $\begin{array}{l}20 \\
29\end{array}$ & $\begin{array}{l}40.8 \\
59.2\end{array}$ & $\begin{array}{r}6 \\
13\end{array}$ & $\begin{array}{r}31.6 \\
.68 .4\end{array}$ & $\begin{array}{l}6 \\
7\end{array}$ & $\begin{array}{l}46.2 \\
53.8\end{array}$ & $\begin{array}{l}0 \\
6\end{array}$ & $\begin{array}{r}0.0 \\
100.0\end{array}$ & $\begin{array}{l}0 \\
1\end{array}$ & $\begin{array}{r}0.0 \\
100.0\end{array}$ \\
\hline Total & $123^{a}$ & 100.0 & 49 & 100.0 & 19 & 100.0 & 13 & 100.0 & 6 & 100.0 & 1 & 100.0 \\
\hline
\end{tabular}

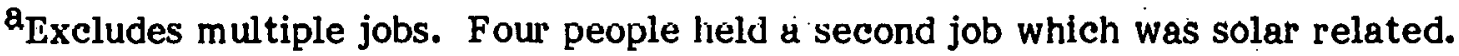


Table 4-24. TYPE OF JOB HELD AFTBR PROGRAM, SOLAR VS. NONSOLAR

(First Job)

\begin{tabular}{|c|c|c|c|c|}
\hline \multirow[b]{3}{*}{ Job Category ${ }^{\mathrm{A}}$} & \multicolumn{4}{|c|}{ Does It Involve Solar? } \\
\hline & \multicolumn{2}{|r|}{ Yes } & \multicolumn{2}{|r|}{ No } \\
\hline & Number & \% of Total "Yes" & Number & \% of Total "No" \\
\hline $\begin{array}{l}\text { Prof essional, technical, } \\
\text { managerial }\end{array}$ & 32 & 45.1 & 1 & 1.9 \\
\hline Clerical & 3 & 4.2 & 3 & 5.8 \\
\hline Sales & 1 & 1.4 & 1 & 1.9 \\
\hline Service occupation & 0 & 0 & 9 & 17.3 \\
\hline $\begin{array}{l}\text { Agricultural, fishing, forestry, } \\
\text { and related occupations }\end{array}$ & 0 & 0 & 4 & 7.7 \\
\hline Processing & 0 & 0 & 3 & 5.8 \\
\hline Machine trades & 0 & 0 & 5 & 9.6 \\
\hline Benchwork & 0 & $\mathbf{0}$ & 4 & 7.7 \\
\hline Structural work & 35 & 49.3 & 16 & 30.8 \\
\hline Miscellaneous & 0 & 0 & 4 & 7.7 \\
\hline Unskilled (unspecified) & $\mathbf{0}$ & 0 & 2 & 3.8 \\
\hline Total ${ }^{\mathrm{b}}$ & 71 & 100.0 & 52 & 100.0 \\
\hline
\end{tabular}

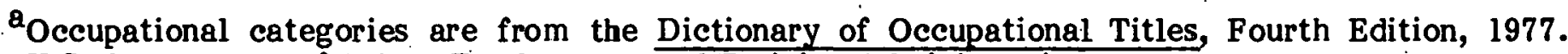
U.S. Department of Labor, Employment and Training Administration.

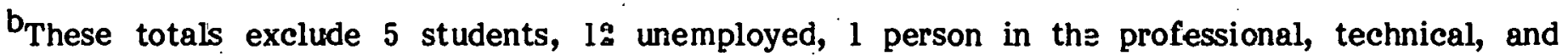
managerial job category who did not respond, 2 in the machine trades category who did not respond, and 1 in the benchwork category who did not respond. 
Table 4-25. PERCENTAGES OF TME ON SOLAR WORK, FOR GRADUATES WTHH SOLAR JOBS

\begin{tabular}{|c|c|c|c|c|c|c|c|c|}
\hline \multirow{2}{*}{$\begin{array}{l}\text { Percentage of Time } \\
\text { on Solar Energy }\end{array}$} & \multicolumn{2}{|c|}{ First Job } & \multicolumn{2}{|c|}{ Second Job } & \multicolumn{2}{|c|}{ Third Job } & \multicolumn{2}{|c|}{ Fourth Job } \\
\hline & No. & \% & No. & $\%$ & No. & $\%$ & No. & $\%$ \\
\hline $1-10 \%$ & 2 & 3.0 & 0 & 0 & & & & \\
\hline $11-25$ & 2 & 3.0 & 2 & 10.5 & & & & \\
\hline $26-50$ & 5 & 7.6 & 0 & 0 & 1 & 16.7 & & \\
\hline $51-75$ & 4 & 6.1 & 2 & 10.5 & & & & \\
\hline $76-100$ & $53^{a}$ & 80.3 & 15 & 79.0 & 5 & 83.3 & 5 & 100.0 \\
\hline Total & $66^{a}$ & 100.0 & 19 & 100.0 & 6 & 100.0 & 5 & 100.0 \\
\hline
\end{tabular}

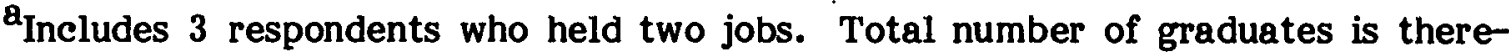
fore 63.

Table 4-26. NUMBER OF SOLAR INSTALLATIONS DONE

\begin{tabular}{ccr}
\hline No. of Installations & No. of Graduates & $\%$ \\
\hline $1-5$ & 28 & 42.4 \\
$6-10$ & 11 & 16.7 \\
$11-20$ & 7 & 10.6 \\
$21-50$ & 6 & 9.1 \\
$51-100$ & 5 & 7.6 \\
$101-250$ & 7 & 10.6 \\
"Several" & 1 & 1.5 \\
"Many" & 1 & 1.5 \\
Total & 66 & 100.0 \\
\hline
\end{tabular}




\subsubsection{Type of Job vs. Previous Rducation}

In Table 4-28, the type of first job participants found upon leaving the CETA program is related to level of education prior to the program. Over $90 \%$ of participants who obtained jobs within the professional-technical-managerial category had either a college degree (59\%) or some college (35\%). In structural work, where $35 \%$ of the participants found jobs, the educational backgrounds were split fairly evenly between those with high school diplomas (41\%; 21 of 51 ) and those who had some college or were college graduates $(53 \% ; 27$ of 51$)$.

\subsubsection{Type of Job vs. Sex}

To examine possible relationships between sex and the types of first jobs participants found after leaving the program, these two variables were cross-tabulated (Table 4-29). Although there the number of males and females in the professional-technical-managerial category was the same (17 each), the relative number of females was considerably higher in that job category ( $40 \%$ of all females interviewed) than the relative number of males ( $17 \%$ of all males interviewed). In the structural job category, 45 respondents were male ( $44 \%$ of all males interviewed) compared with 6 females ( $14 \%$ of all females interviewed). The comparatively low percentage of females in this category may indicate that women are encountering difficulties in breaking into traditionally "male" occupations; e.g., construction trades. This finding is supported by several of the CETA program managers, who stated that it was difficult to place female students in the construction industry (see Sec. 3.0). Out of the 12 participants who listed "unemployed" when asked about their first job, 11 were male (11\% of all males interviewed) while one was female ( $2 \%$ of all females interviewed).

\subsubsection{Type of Job vs. Ethnic Background}

As indicated by the data in Table 4-30, the professional-technical-managerial category is dominated (76\%) by white participants. In terms of the total sample, 35\% of whites, $7 \%$ of blacks, $12.5 \%$ of Hispanics, and 37.5\% of those in the "other" category listed their first job in the professional-technical-managerial occupational class.

The ethnic distribution relative to the sample in the structural work category was much more even than in the professional-technical-managerial category. In structural work, 29 were white (39\% of all white respondents), 10 were black (23\% of all black respondents), 6 were Hispanic (37.5\% of all Hispanic respondents), and 5 were "other" (62.5\% of all "other" respondents). Of those who responded "unemployed," 4 were white (5\% of all white respondents), 5 were black ( $12 \%$ of all black respondents), and 3 were Hispanics (19\% of all Hispanic respondents).

\subsubsection{Solar Jobs vs. Previous Education}

The data in Table 4-31 suggest that there is some correlation between level of prior education and placement in solar jobs. Of those whose first job involved solar, 76\% (54 of 71) had some college or were college graduates. Only $21 \%$ (14 of 68) of those with college experience or degrees were in nonsolar jobs. 
Table 4-28. FIRST JOB BY HIGHEST GRADB COMPLETED IN SCHOOL

\begin{tabular}{|c|c|c|c|c|c|c|}
\hline Job Category & $\begin{array}{c}\text { Some } \\
\text { High School }\end{array}$ & $\begin{array}{l}\text { High School } \\
\text { Graduate }\end{array}$ & $\begin{array}{l}\text { Post-High School } \\
\text { (Not College) }\end{array}$ & Some College & College Degree & Total \\
\hline $\begin{array}{l}\text { Professional, } \\
\text { technical, \& } \\
\text { managerial }\end{array}$ & & $\begin{array}{l}3^{a} \\
8.8^{b} \\
5.9^{c}\end{array}$ & & $\begin{array}{l}21 \\
61.8 \\
35.0\end{array}$ & $\begin{array}{l}10 \\
29.4 \\
58.8\end{array}$ & $\begin{array}{c}34 \\
100.0 \\
23.6\end{array}$ \\
\hline Clerical & $\begin{array}{c}2 \\
33.3 \\
15.4\end{array}$ & $\begin{array}{c}2 \\
33.3 \\
3 . \mathrm{s}\end{array}$ & & $\begin{array}{r}2 \\
33.3 \\
3.3\end{array}$ & & $\begin{array}{r}6 \\
100.0 \\
4.2\end{array}$ \\
\hline Sales & & & & $\begin{array}{r}2 \\
100.0 \\
3.3\end{array}$ & & $\begin{array}{r}2 \\
100.0 \\
1.4\end{array}$ \\
\hline Service & $\begin{array}{c}2 \\
22.2 \\
15.4\end{array}$ & $\begin{array}{c}5 \\
55.6 \\
9.8\end{array}$ & & $\begin{array}{c}2 \\
22.2 \\
3.3\end{array}$ & & $\begin{array}{r}9 \\
100.0 \\
6.3\end{array}$ \\
\hline $\begin{array}{l}\text { Agricultural, } \\
\text { fishery, forestry, } \\
\text { and related occupations }\end{array}$ & $\begin{array}{l}2 \\
50.0 \\
15.4\end{array}$ & $\begin{array}{c}2 \\
50.0 \\
3 . c\end{array}$ & & & & $\begin{array}{r}4 \\
100.0 \\
2.8\end{array}$ \\
\hline Processing & & $\begin{array}{r}2 \\
66 . \bar{\tau} \\
3.5\end{array}$ & & $\begin{array}{c}1 \\
33.3 \\
1.7\end{array}$ & . & $\begin{array}{c}3 \\
100.0 \\
2.1\end{array}$ \\
\hline Machine & $\begin{array}{c}2 \\
28.6 \\
15.4\end{array}$ & $\begin{array}{r}3 \\
42 . \mathrm{c} \\
5 . \mathrm{c}\end{array}$ & & $\begin{array}{r}2 \\
28.6 \\
3.3\end{array}$ & & $\begin{array}{r}7 \\
100.0 \\
4.9\end{array}$ \\
\hline Benchwork & & $\begin{array}{l}3 \\
60 . c \\
5.5\end{array}$ & & $\begin{array}{c}2 \\
40.0 \\
3.3\end{array}$ & & $\begin{array}{r}5 \\
100.0 \\
3.5\end{array}$ \\
\hline Structural & $\begin{array}{l}1 \\
2.0 \\
7.7\end{array}$ & $\begin{array}{l}21 \\
41.2 \\
41 . \varepsilon\end{array}$ & $\begin{array}{c}2 \\
3.9 \\
100.0\end{array}$ & $\begin{array}{l}23 \\
45.1 \\
38.3\end{array}$ & $\begin{array}{c}4 \\
7.8 \\
23.5\end{array}$ & $\begin{array}{r}51 \\
100.0 \\
35.4\end{array}$ \\
\hline
\end{tabular}


Table 4-28. FIRST JOB BY HIGHEST GRADE COMPLETED IN SCHOOL

(Concluded)

\begin{tabular}{|c|c|c|c|c|c|c|c|}
\hline Job Category & 8th Grade & $\begin{array}{c}\text { Some } \\
\text { High Schooi }\end{array}$ & $\begin{array}{l}\text { High School } \\
\text { Graduate }\end{array}$ & $\begin{array}{l}\text { Post-High School } \\
\text { (Not College) }\end{array}$ & Some College & College Degree & Total \\
\hline Miscellaneous & & & $\begin{array}{r}3^{\mathrm{a}} \\
75.0^{\mathrm{b}} \\
5.9^{\mathrm{c}}\end{array}$ & & $\begin{array}{r}1 \\
25.0 \\
1.7\end{array}$ & & $\begin{array}{r}4 \\
100.0 \\
2.8\end{array}$ \\
\hline Unskilled & & $\begin{array}{r}1 \\
50.0 \\
7.7\end{array}$ & $\begin{array}{r}1 \\
50.0 \\
2.0\end{array}$ & & $\begin{array}{r}2.0 \\
100.0 \\
1.4\end{array}$ & & \\
\hline Students & & $\begin{array}{r}1 \\
20.0 \\
7.7\end{array}$ & & & $\begin{array}{r}3 \\
60.0 \\
5.0\end{array}$ & $\begin{array}{r}1 \\
20.0 \\
5.9\end{array}$ & $\begin{array}{c}5 \\
100.0 \\
3.5\end{array}$ \\
\hline Unemployed & $\begin{array}{r}1 \\
8.3 \\
100.0\end{array}$ & $\begin{array}{c}2 \\
16.7 \\
15.4\end{array}$ & $\begin{array}{c}6 \\
50.0 \\
11.8\end{array}$ & & $\begin{array}{l}1 \\
8.3 \\
1.7\end{array}$ & $\begin{array}{c}2 \\
16.7 \\
11.8\end{array}$ & $\begin{array}{r}12 \\
100.0 \\
8.3\end{array}$ \\
\hline $\begin{array}{l}\text { Total } \\
\%\end{array}$ & $\begin{array}{l}1 \\
0.7\end{array}$ & $\begin{array}{l}13 \\
9.0\end{array}$ & $\begin{array}{l}51 \\
35.4\end{array}$ & $\begin{array}{l}2 \\
1.4\end{array}$ & $\begin{array}{l}60 \\
41.7\end{array}$ & $\begin{array}{l}17 \\
11.8\end{array}$ & 144 \\
\hline
\end{tabular}

${ }^{a}$ Count.

bow \%.

column \%. 
Table 4-29. FIRST JOB, BY SEX

\begin{tabular}{|c|c|c|c|}
\hline \multirow[b]{2}{*}{ Job Category } & \multicolumn{2}{|c|}{ Sex } & \multirow[b]{2}{*}{ - Total } \\
\hline & Male & Female & \\
\hline $\begin{array}{l}\text { Professional, } \\
\text { technical, \& } \\
\text { managerial }\end{array}$ & $\begin{array}{l}17^{\mathrm{a}} \\
50.0^{\mathrm{b}} \\
16.7^{\mathrm{c}}\end{array}$ & $\begin{array}{l}17 \\
50.0 \\
40.5\end{array}$ & $\begin{array}{c}34 \\
100.0 \\
23.6\end{array}$ \\
\hline Clerical & $\begin{array}{l}0 \\
0 \\
0\end{array}$ & $\begin{array}{c}6 \\
100.00 \\
14.3\end{array}$ & $\begin{array}{r}6 \\
100.0 \\
4.2\end{array}$ \\
\hline Sales & $\begin{array}{c}2 \\
100.0 \\
\quad 2.0\end{array}$ & $\begin{array}{l}0 \\
0 \\
0\end{array}$ & $\begin{array}{r}2 \\
100.0 \\
1.4\end{array}$ \\
\hline Service & $\begin{array}{r}5 \\
55.6 \\
4.9\end{array}$ & $\begin{array}{r}4 \\
44.4 \\
9.5\end{array}$ & $\begin{array}{c}9 \\
100.0 \\
6.3\end{array}$ \\
\hline $\begin{array}{l}\text { Agricultural, } \\
\text { fisheries, } \\
\text { forestry, and } \\
\text { related occuptions }\end{array}$ & $\begin{array}{r}4 \\
100.0 \\
3.9\end{array}$ & $\begin{array}{l}0 \\
0 \\
0\end{array}$ & $\begin{array}{r}4 \\
100.0 \\
2.8\end{array}$ \\
\hline Processing & $\begin{array}{c}3 \\
100.0 \\
2.9\end{array}$ & $\begin{array}{l}0 \\
0 \\
0\end{array}$ & $\begin{array}{r}3 \\
100.0 \\
2.1\end{array}$ \\
\hline Machine trade & $\begin{array}{r}6 \\
85.7 \\
5.9\end{array}$ & $\begin{array}{c}1 \\
14.3 \\
2.4\end{array}$ & $\begin{array}{r}7 \\
100.0 \\
4.9\end{array}$ \\
\hline Benchwork & $\begin{array}{l}2 \\
40.0 \\
2.0\end{array}$ & $\begin{array}{l}3 \\
60.0 \\
7.1\end{array}$ & $\begin{array}{r}5 \\
100.0 \\
3.5\end{array}$ \\
\hline Structural & $\begin{array}{l}45 \\
88.2 \\
44.1\end{array}$ & $\begin{array}{l}6 \\
11.8 \\
14.3\end{array}$ & $\begin{array}{c}51 \\
100.0 \\
35.4\end{array}$ \\
\hline Miscellaneous & $\begin{array}{l}2 \\
50.0 \\
2.0\end{array}$ & $\begin{array}{l}2 \\
50.0 \\
4.8\end{array}$ & $\begin{array}{r}4 \\
100.0 \\
2.8\end{array}$ \\
\hline Unskilled & $\begin{array}{r}1 \\
50.0 \\
1.0\end{array}$ & $\begin{array}{c}1 \\
50.0 \\
2.4\end{array}$ & $\begin{array}{r}2 \\
100.0 \\
1.4\end{array}$ \\
\hline Students & $\begin{array}{r}4 \\
80.0 \\
3.9\end{array}$ & $\begin{array}{c}1 \\
20.0 \\
2.4\end{array}$ & $\begin{array}{r}5 \\
100.0 \\
3.5\end{array}$ \\
\hline Unemployed & $\begin{array}{l}11 \\
91.7 \\
10.8\end{array}$ & $\begin{array}{l}1 \\
8.3 \\
2.4\end{array}$ & $\begin{array}{r}12 \\
100.0 \\
8.3\end{array}$ \\
\hline $\begin{array}{l}\text { Total } \\
\%\end{array}$ & $\begin{array}{r}102.0 \\
70.8\end{array}$ & $\begin{array}{l}42.0 \\
29.2\end{array}$ & 144 \\
\hline
\end{tabular}

${ }^{\mathrm{a}}$ Count.

bow \%.

${ }^{c}$ Column \%. 
Table 4-30. FIRST JOB, BY RACIAL/ETHNIC BACKGROUND

\begin{tabular}{|c|c|c|c|c|c|}
\hline \multirow[b]{2}{*}{ Job Category } & \multicolumn{4}{|c|}{ Racial/Ethnic Background } & \multirow[b]{2}{*}{ Total } \\
\hline & White & Black & Hispanic & Other & \\
\hline $\begin{array}{l}\text { Professional, } \\
\text { technical, \& } \\
\text { managerial }\end{array}$ & $\begin{array}{l}26^{\mathrm{a}} \\
76.5^{\mathrm{b}} \\
34.7^{\mathrm{c}}\end{array}$ & $\begin{array}{l}3 \\
8.8 \\
7.0\end{array}$ & $\begin{array}{c}2 \\
5.9 \\
12.5\end{array}$ & $\begin{array}{l}3 \\
8.8 \\
37.5\end{array}$ & $\begin{array}{r}34 \\
100.0 \\
23.9\end{array}$ \\
\hline Clerical & $\begin{array}{c}2 \\
33.3 \\
2.7\end{array}$ & $\begin{array}{c}4 \\
66.7 \\
9.3\end{array}$ & & & $\begin{array}{r}6 \\
100.0 \\
4.2\end{array}$ \\
\hline Sales & $\begin{array}{r}2 \\
100.0 \\
2.7\end{array}$ & & & & $\begin{array}{r}2 \\
100.0 \\
1.4\end{array}$ \\
\hline Service & $\begin{array}{l}3 \\
33.3 \\
4.0\end{array}$ & $\begin{array}{c}6 \\
66.7 \\
13.9\end{array}$ & . & & $\begin{array}{r}9 \\
100.0 \\
6.3\end{array}$ \\
\hline $\begin{array}{l}\text { Agricultural, } \\
\text { fishing, for- } \\
\text { estry, \& related }\end{array}$ & $\begin{array}{c}1 \\
25.0 \\
1.3\end{array}$ & $\begin{array}{c}2 \\
50.0 \\
4.6\end{array}$ & $\begin{array}{r}1 \\
25.0 \\
6.2\end{array}$ & & $\begin{array}{r}4 \\
100.0 \\
2.8\end{array}$ \\
\hline Processing & & $\begin{array}{r}2 \\
66.7 \\
4.6\end{array}$ & $\begin{array}{r}1 \\
33.3 \\
6.2\end{array}$ & & $\begin{array}{r}3 \\
100.0 \\
2.1\end{array}$ \\
\hline Machine & $\begin{array}{c}4 \\
57.1 \\
5.3\end{array}$ & $\begin{array}{r}1 \\
14.3 \\
2.3\end{array}$ & $\begin{array}{c}2 \\
28.6 \\
12.5\end{array}$ & & $\begin{array}{r}7 \\
100.0 \\
4.9\end{array}$ \\
\hline Benchwork & & $\begin{array}{c}3 \\
75.0 \\
7.0\end{array}$ & $\begin{array}{r}1 \\
25.0 \\
6.2\end{array}$ & & $\begin{array}{r}4 \\
100.0 \\
2.8\end{array}$ \\
\hline Structural & $\begin{array}{l}29 \\
58.0 \\
38.7\end{array}$ & $\begin{array}{l}10 \\
20.0 \\
23.3\end{array}$ & $\begin{array}{c}6 \\
12.0 \\
37.5\end{array}$ & $\begin{array}{c}5 \\
10.0 \\
62.5\end{array}$ & $\begin{array}{l}50 \\
100.0 \\
35.2\end{array}$ \\
\hline Miscellaneous & $\begin{array}{c}1 \\
25.0 \\
1.3\end{array}$ & $\begin{array}{r}3 \\
75.0 \\
7.0\end{array}$ & . & & $\begin{array}{r}4 \\
100.0 \\
2.8\end{array}$ \\
\hline Unskilied & & $\begin{array}{r}2 \\
100.0 \\
4.6\end{array}$ & & & $\begin{array}{r}2 \\
100.0 \\
1.4\end{array}$ \\
\hline Students & $\begin{array}{l}3 \\
6 \cap .0 \\
4.0\end{array}$ & $\begin{array}{c}2 \\
40.0 \\
4.6\end{array}$ & & & $\begin{array}{r}5 \\
100.0 \\
3.5\end{array}$ \\
\hline Unemployed & $\begin{array}{c}4 \\
33.3 \\
5.3\end{array}$ & $\begin{array}{l}5 \\
41.7 \\
11.6\end{array}$ & $\begin{array}{c}3 \\
25.0 \\
18.8\end{array}$ & & $\begin{array}{r}12 \\
100.0 \\
8.5\end{array}$ \\
\hline $\begin{array}{l}\text { Total } \\
\%\end{array}$ & $\begin{array}{l}75 \\
52.8\end{array}$ & $\begin{array}{l}43 \\
30.3\end{array}$ & $\begin{array}{l}16 \\
11.3\end{array}$ & $\begin{array}{l}8 \\
5.6\end{array}$ & $\begin{array}{l}142 \\
100.0\end{array}$ \\
\hline
\end{tabular}


Table 4-31. WAS YOUR FIRST JOB IN SOLAR ENERGY FIELD? (BY GRADE IN SCHOOL)

\begin{tabular}{|c|c|c|c|}
\hline \multirow[b]{2}{*}{ Highest Grade Completed } & \multicolumn{2}{|c|}{ Involves Solar? } & \multirow[b]{2}{*}{ Total } \\
\hline & Yes & No & \\
\hline Some high school & $\begin{array}{l}0^{\mathrm{a}} \\
0^{\mathrm{b}} \\
0^{\mathrm{c}}\end{array}$ & $\begin{array}{c}9 \\
100.0 \\
17.3\end{array}$ & $\begin{array}{r}9 \\
100.0 \\
7.3\end{array}$ \\
\hline High school graduate & $\begin{array}{l}16 \\
36.4 \\
22.5\end{array}$ & $\begin{array}{l}28 \\
63.6 \\
53.8\end{array}$ & $\begin{array}{r}44 \\
100.0 \\
35.8\end{array}$ \\
\hline $\begin{array}{l}\text { Post-high school } \\
\text { (other than college) }\end{array}$ & $\begin{array}{c}1 \\
50.0 \\
1.4\end{array}$ & $\begin{array}{r}1 \\
50.0 \\
1.9\end{array}$ & $\begin{array}{r}2 \\
100.0 \\
1.6\end{array}$ \\
\hline Some college & $\begin{array}{l}40 \\
76.0 \\
56.3\end{array}$ & $\begin{array}{l}12 \\
33.1 \\
23.1\end{array}$ & $\begin{array}{r}52 \\
100.0 \\
42.3\end{array}$ \\
\hline College degree & $\begin{array}{l}14 \\
87.5 \\
19.7\end{array}$ & $\begin{array}{r}2 \\
12.5 \\
3.8\end{array}$ & $\begin{array}{l}16 \\
100.0 \\
13.0\end{array}$ \\
\hline $\begin{array}{l}\text { Total } \\
\%\end{array}$ & $\begin{array}{l}71 \\
57.7\end{array}$ & $\begin{array}{l}52 \\
42.3\end{array}$ & $\begin{array}{l}123 \\
100.0\end{array}$ \\
\hline $\begin{array}{l}\mathrm{a}_{\text {Count. }} \\
\mathrm{b}_{\text {Row } \% .} \\
{ }^{c_{\text {Column }} \% .}\end{array}$ & & & - \\
\hline
\end{tabular}




\subsubsection{Solar Jobs vs. Sex}

Sex does not appear to be an important factor in terms of those who obtained solar versus nonsolar jobs (Table 4-32). An equal percentage (58\%) of males and females interviewed listed their first job as involving solar energy.

\subsubsection{Solar Jobs vs. Bthnic Background}

In Table 4-33, solar jobs are related to the racial/ethnic backgrounds of the participants. These data indicate there is a significant difference between whites and nonwhites in terms of finding solar jobs. Of all white respondents, 78.5\% listed their first job as involving solar energy; of all nonwhite respondents, $33 \%$ were employed in solar jobs.

\subsubsection{Sex and Age vs. Wage Rates}

In Table 4-34, ethnic background (white and nonwhite) and sex are related to average hourly wage .rates in the first jobs found by participants. With respect to sex, there appears to be no significant pattern in wage levels. However, there does appear to be some "clustering" in relation to racial/ethnic groups. Only 1 white ( $1.8 \%$ of whites) listed his/her top wage rate for the first job as less than $\$ 3.01 / \mathrm{hr}$, while 11 nonwhites $(22.4 \%$ of nonwhites) earned less than this hourly rate. Those listing their top wage rate above $\$ 5.00 / \mathrm{hr}$ included $44 \%$ of all white respondents (25 to 57 ) and $35 \%$ of all nonwhite respondents (17 of 49 ).

\subsubsection{Solar Jobs vs. Wage Rates}

For both initial and top wage rates (Table 4-35), more participants whose jobs involved solar energy were in higher wage-rate categories than those whose jobs did not. For their initial wage rate, $31 \%$ of those in solar jobs were earning over $\$ 5.00 / \mathrm{hr}$, compared with $8 \%$ of those in nonsolar jobs. For their top wage rate, $80 \%$ of the respondents in solar jobs were earning over $\$ 5.00 / \mathrm{hr}$, compared with $30 \%$ of those in nonsolar jobs. 
Table 4-32. WAS YOUR FIRST JOB IN SOLAR ENERGY FIELD? (BY SEX)

\begin{tabular}{|c|c|c|c|}
\hline & \multicolumn{2}{|c|}{ Involves Solar? } & \multirow[b]{2}{*}{ Total } \\
\hline & Yes & No & \\
\hline Male & $\begin{array}{l}49^{\mathrm{a}} \\
57.6^{\mathrm{b}} \\
69.0^{\mathrm{c}}\end{array}$ & $\begin{array}{l}36 \\
42.4 \\
69.2\end{array}$ & $\begin{array}{c}85 \\
100.0 \\
69.1\end{array}$ \\
\hline Female & $\begin{array}{l}22 \\
57.9 \\
31.0\end{array}$ & $\begin{array}{l}16 \\
42.1 \\
30.8\end{array}$ & $\begin{array}{c}38 \\
100.0 \\
30.9\end{array}$ \\
\hline $\begin{array}{l}\text { Total } \\
\%\end{array}$ & $\begin{array}{l}71 \\
57.7\end{array}$ & $\begin{array}{l}52 \\
42.3\end{array}$ & $\begin{array}{l}123 \\
100.0\end{array}$ \\
\hline
\end{tabular}

Table 4-33. WAS YOUR FIRST JOB IN SOLAR BNERGY FIELD? (BY ETHNIC BACKGROUND)

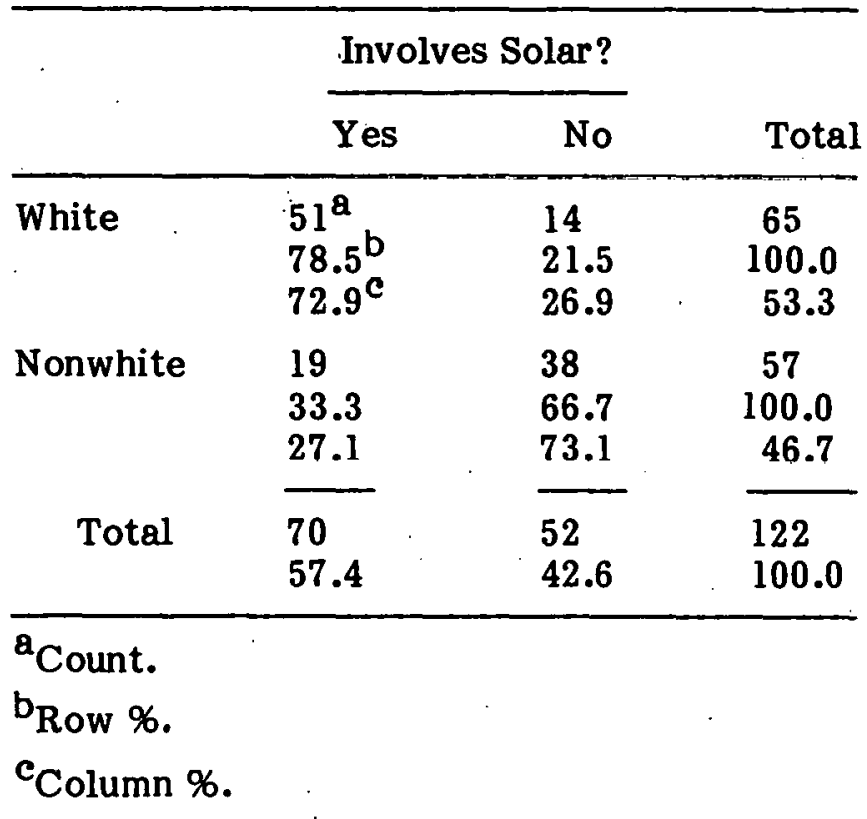


Table 4-34. TOP WAGE RATE, FIRST JOB

\begin{tabular}{|c|c|c|c|c|c|c|c|c|c|c|c|c|}
\hline & \multirow[b]{2}{*}{ Sex } & \multicolumn{10}{|c|}{ Hourly Wage Rate } & \multirow[b]{2}{*}{ Total } \\
\hline & & $\leq 3.00$ & $3.01-3.50$ & $3.51-4.00$ & $4.01-4.50$ & $4.51-5.00$ & $5.01-5.50$ & $5.51-6.50$ & $6.51-7.50$ & $7.51-8.50$ & 8.50 & \\
\hline \multirow[t]{2}{*}{ White } & Male & $\begin{array}{l}1^{a} \\
8.3^{b}\end{array}$ & $\begin{array}{c}4 \\
25.0\end{array}$ & $\begin{array}{c}7 \\
43.7\end{array}$ & $\begin{array}{c}4 \\
57.1\end{array}$ & $\begin{array}{c}7 \\
53.8\end{array}$ & $\begin{array}{c}5 \\
50.0\end{array}$ & $\begin{array}{c}4 \\
40.0\end{array}$ & $\begin{array}{c}4 \\
33.3\end{array}$ & $\begin{array}{c}1 \\
25.0\end{array}$ & $\begin{array}{c}3 \\
50.0\end{array}$ & $\begin{array}{l}40 \\
37.7\end{array}$ \\
\hline & Female & & $\begin{array}{c}2 \\
12.5\end{array}$ & $\begin{array}{c}4 \\
25.0\end{array}$ & $\begin{array}{c}1 \\
14.3\end{array}$ & $\begin{array}{c}2 \\
15.4\end{array}$ & $\begin{array}{c}1 \\
10.0\end{array}$ & $\begin{array}{c}2 \\
20.0\end{array}$ & $\begin{array}{c}3 \\
25.0\end{array}$ & $\begin{array}{c}1 \\
25.0\end{array}$ & $\begin{array}{l}1 \\
16.7\end{array}$ & $\begin{array}{l}17 \\
16.0\end{array}$ \\
\hline \multirow[t]{4}{*}{ Nonwhite } & Male & $\stackrel{9}{75.0}$ & $\begin{array}{c}6 \\
37.5\end{array}$ & $\begin{array}{c}3 \\
18.7\end{array}$ & $\begin{array}{c}2 \\
28.6\end{array}$ & $\begin{array}{c}2 \\
15.4\end{array}$ & $\begin{array}{c}3 \\
30.0\end{array}$ & $\begin{array}{c}3 \\
30.0\end{array}$ & $\begin{array}{c}2 \\
16.7 .\end{array}$ & $\begin{array}{c}2 \\
50.0\end{array}$ & $\begin{array}{c}2 \\
33.3\end{array}$ & $\begin{array}{l}34 \\
32.1\end{array}$ \\
\hline & Female & $\begin{array}{c}2 \\
16.7\end{array}$ & $\begin{array}{c}4 \\
25.0\end{array}$ & $\begin{array}{c}2 \\
12.5\end{array}$ & & $\begin{array}{c}2 \\
15.4\end{array}$ & $\begin{array}{c}1 \\
10.0\end{array}$ & $\begin{array}{c}1 \\
10.0\end{array}$ & $\begin{array}{c}3 \\
25.0\end{array}$ & & & $\begin{array}{l}15 \\
14.1\end{array}$ \\
\hline & $\mathrm{al}^{\mathrm{c}}$ & 12 & 16 & 16 & 7 & 13 & 10 & 10 & 12 & 4 & 6 & 106 \\
\hline & $\begin{array}{l}\text { n each } \\
\text { nge }\end{array}$ & il.3 & 15.1 & 15.1 & 6.6 & 12.3 & 9.4 & 9.4 & 11.3 & 3.8 & 5.7 & 100.0 \\
\hline
\end{tabular}

a Number.

bColumn \%.

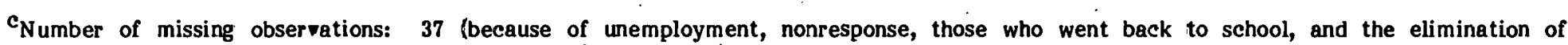

respondents whose wages were based on some sort of commission). 
Table 4-35. INITIAL WAGE RATE, FIRST JOB

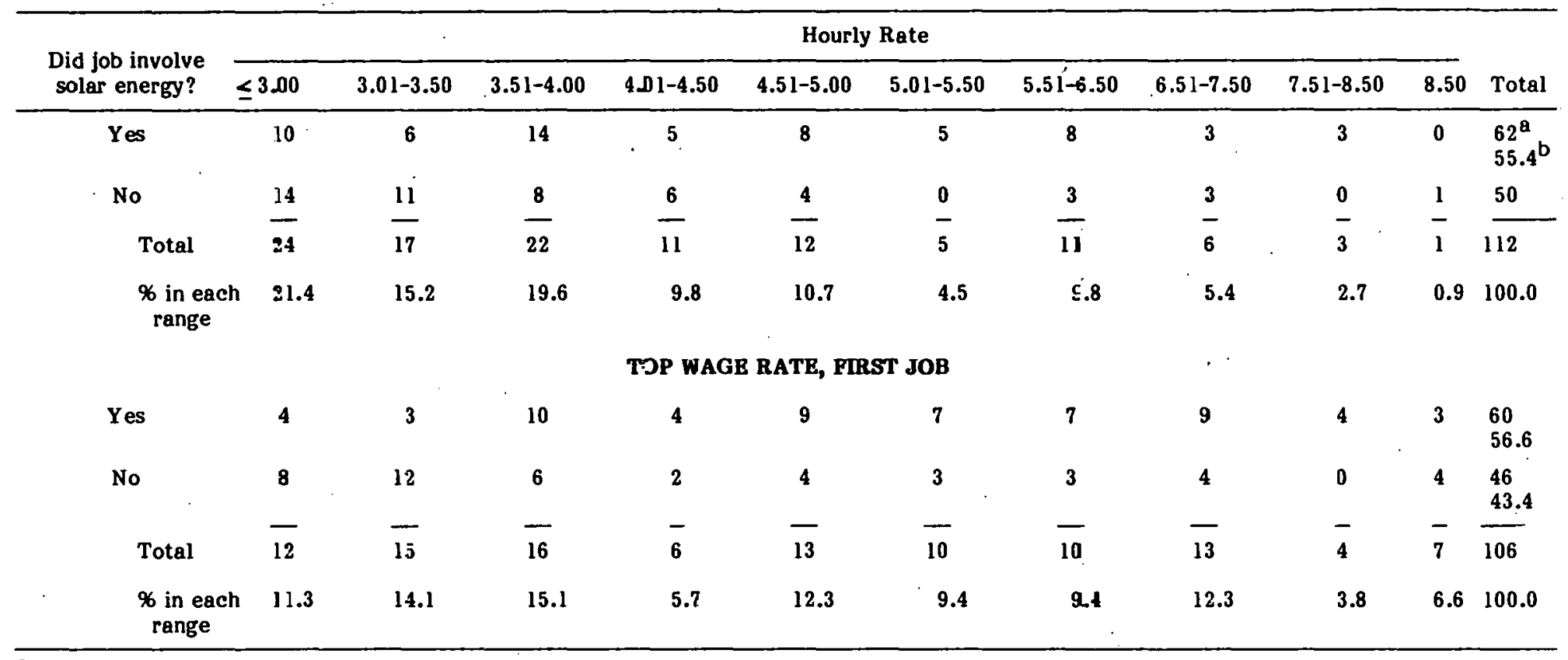

${ }^{\mathrm{a}}$ Count.

bColumn \%. 


\section{SECTION 5.0}

\section{CONCLUSIONS AND RECOMMENDATIONS}

\subsection{SUMMARY AND CONCLUSIONS}

As indicated in the discussion of the training programs in Sec. 3.0, the CETA solar training efforts in California vary widely in terms of program content and length, objectives, and clientele. This diversity makes it difficult to provide general statements about many key questions and issues surrounding CETA-funded solar training programs. It must be emphasized that the major purpose of this study was not to pass judgment on the relative success or failure of these programs, but rather to collect, analyze, and communicate information gathered on solar training from these initial efforts. With this objective in mind, some of the more important findings about the programs and their graduates can be summarized.

\subsubsection{Graduate Experiences}

In any CETA training effort-solar or otherwise-the primary objective is to provide students with skills sufficient to secure employment. The program directors, therefore, felt that successful job placement of graduates should include employment in a variety of fields related to their training, such as general construction and manufacturing, as well as in the solar industry. Consideration should also be given to the fact that many CETA participants lack basic education and job behavior skills. Placement in any job-and continuation in employment-indicates that the basic work skill and job behavior component of the training program has been effective, even if the specific vocational skills gained in the program are not being used.

Viewed in this broad perspective, the California solar programs have achieved relatively high levels of job placements for their graduates. Of the 144 participants interviewed, 132 found immediate employment upon leaving the program. The percentage of participants unemployed increased after their initial placement; $21 \%$ * were unemployed at the time of the interview.

For the participants in the California CETA solar programs who were able to find jobs, they were generally full-time and fairly high-paying jobs. Only $13 \%$ of the students reported that they were working 30 or fewer hours per week. Almost as many respondents (12\%) reported that they were working more than 40 hours per week. Initial and final wages for the participants' first jobs averaged $\$ 4.33 / \mathrm{hr}$ and $\$ 5.20 / \mathrm{hr}$, respectively. For those who moved into other jobs, the comparative averages in the third job held after leaving the program were $\$ 6.34 / \mathrm{hr}$ and $\$ 6.64 / \mathrm{hr}$.

In terms of types of jobs found by program participants, four categories-professional, technical, and managerial (23.6\%); structural work (35.4\%); service occupations (6.3\%); and machine trades (4.9\%)-accounted for more than $70 \%$ of the first jobs listed by respondents. As indicated by the program discussion in Sec. 3.0, three general types of skills training were offered by the California CETA programs: technical (system design

*Includes 7 nongraduates who were unemployed. Excluding these nongraduates, the percentage of unemployed graduates becomes $18 \%$ (23 of 126 ). 
and sizing), structural (installation), and assembly (manufacturing). It appears, given these objectives, that a large majority of the graduates were able to use their general skills training.

The majority of respondents (58\%) indicated that their first job after graduation involved solar energy. Most of the graduates who found jobs in solar-related fields spent close to full time on solar activities; $80 \%$ of those whose first job had some solar component reported that they spent more than three-quarters of their work time on solar energyrelated activities.

Overall, the participants were generally satișfied with the training they received in the solar programs. The majority of the participants felt that the training program adequately prepared them for their current work. However, there were several problems mentioned by significant numbers of students. The most frequent suggestions for program improvement included reducing bureaucratic problems and "red tape," lengthening the training period, and improving job placement assistance. Other items mentioned for improvement were more in-depth or specific training, more individual attention, and better organization or administration.

\subsubsection{Program Information}

In the course of collecting information about the California programs, several important considerations about CETA solar training efforts were identified. These generic issues were raised mostly by program personnel, and thus reflect the perspective of those who are actively engaged in providing solar training with CETA funds.

One of the common issues mentioned by program personnel-which is highlighted in the program descriptions-is that solar CETA training is a highly diverse endeavor. This diversity is the result of varying and multiple objectives of the programs and their sponsors, a heterogeneous clientele, and local market conditions. The training aspect of these programs, again, had three major components: basic education and job behavior, general trade skills, and specific training in solar technology. It appears crucial that those involved in CETA solar training consider these three basic components, both in terms of designing training programs and in assessing the relative success of a program. For some participants, a "successful" placement would be in virtually any job, while others would require employment that involves the specific solar knowledge they gained.

A second area of concern revolves around relationships with funding agencies, particularly between CETA prime sponsors and the training programs. A major area of conflict appears to be in the pressure put on training programs to find jobs for graduates. Training program personnel felt that this placement pressure decreased their ability to find solar jobs for graduates, yet they encountered criticism for not placing students in the solar industry. Given the multiple objectives of CETA solar training programs, it is important for prime sponsors to use criteria broader than solar versus nonsolar job placement in determining program effectiveness. A related consideration is that the solar industry is an immature one and is dominated by small (and of ten struggling) companies that are likely to offer relatively low wage rates. As the industry develops, it is likely that prevailing wages will more closely reflect those in similar industries; e.g., construction and HVAC. Funding agencies should consider this fact in assessing shortterm results from training programs. This is also an important consideration for prospective students; many program personnel sensed that student expectations for solar jobs were unrealistic, both in terms of types of work (i.e., "glamour" jobs rather than 
basic construction) and industry wage rates. A final problem voiced by training program managers with respect to funding agencies is that costs for training-related equipment for solar courses are fairly high. To provide adequate hands-on training, a shop with equipment from a variety of construction trades is required. This equipment represents a high start-up cost, and it must be functioning in a timely fashion if training is to be effective.

A third finding from program experiences is that CETA solar training programs must be flexible in content and curricula. This flexibility is necessary because of three basic factors. First, program participants vary widely in education, skills, and ability. To meet varying needs of students, some degree of tailoring must occur. Second, jobs in the industry differ widely, both geographically and over time. Third, CETA solar programs prepare students for a range of occupations, from basic construction and manufacture to solar system design. To provide this flexibility, several programs have modularized their curricula, so that each cycle of a course can be modified to meet the needs of each set of students in light of current employment opportunities.

Program personnel were virtually unanimous in advocating the need for combining conservation and weatherization efforts with solar training. This coordination serves two functions. First, buildings must be weatherized before solar systems are installed in them. Students with training in both weatherization and solar installation are therefore better prepared to offer the integrated skills needed by the industry. Second, the weatherization field currently off ers greater opportunities than the solar industry. Entry into the energy field is more likely to be obtained via the conservation route, while later work may combine solar and conservation.

In designing CETA solar training programs, local employment opportunities must be assessed carefully. Otherwise, programs run the risk of preparing students for jobs that are not available. One way many of the California programs gained this information was through a program advisory board, comprised largely of members of the local solar industry. These advisory boards have been used successfully to ensure that the types of training needed by local industry are provided and to develop relationships between the programs and industry that facilitate placement of graduates.

In some cases, local unions have also been represented on program advisory boards. At this stage, it appears that trade-union participation in the California CETA programs has been limited to individual union members sitting on advisory boards and providing some part-time teaching assistance. In areas with strong unions, trade-union approval of the programs was required by the prime sponsor. Some active support from local unions has been obtained by the CETA programs, but territorial concerns have apparently dampened union enthusiasm. This union response seems to be typical of any CETA effort, not just solar programs.

A final observation about the California CETA programs concerns the effect of demonstrations on neighborhoods-an important aspect of community-based solar training efforts. Installation of solar systems on low-income residents' houses serves the dual function of providing students with hands-on experience and demonstrating to lowincome residents that solar energy is not just for the wealthy. Several programs initially reported difficulty in locating low-income homes to retrofit. Once residents were able to see that the systems worked and saved them money, they readily volunteered to have their homes retrofitted. For some programs, funding for demonstration installations has been a problem. CETA funds are very limited for these types of equipment purchases, and other funding, such as from CSA, DOE, and HUD, had to be obtained. 


\subsection{RECOMMENDATIONS}

Rising prices and the increasing scarcity of conventional fuels make it likely that the solar industry will expand rapidly. If solar energy is to contribute significantly to the nation's energy supply, a substantial and well-trained solar work force will be needed. Training and education requirements of this work force will probably be met by a variety of institutions and programs. Preliminary evidence from the experience in California suggests that CETA (or other community-based training efforts) can assume an important role in meeting the needs of a new industry and a specific training clientele. Many federal, state, and local policies and programs must be initiated or modified and several important issues must be resolved before this potential can be realized.

First, the value of information exchange about solar training efforts and follow-up on these programs cannot be overemphasized. The California programs must be regarded as demonstrations or experiments. In the absence of channels to collect and exchange information, the opportunity to learn from the experiences of others is lost. Information based on program experience can be used by community-based organizations providing (or planning to become involved in) solar training, prime sponsors, and governmental agencies with interest and responsibilities in solar energy program development. To ensure that these information exchange activities are comprehensive and consistent, federal agencies (e.g., DOE and DOL) and state agencies should assume lead roles.

A corollary to the value of information exchange is curricula development for solar training programs. Most of the programs in California basically have developed their own curricula and modified them according to experience. As a result, there has probably been some duplication of effort. One method to reduce this inefficiency is for a central agency-such as a state or federal agency-to develop a consensual, standardized curriculum for CETA solar training programs (as has been done by the State of California's Office of Appropriate Technology). Such a curriculum should be made available to training agencies and prime sponsors, and its adoption encouraged rather than mandated. To ensure that the needs of the students and local industry are met, flexibility at the local level must be maintained.

A second major issue that needs to be clarified is the primary objective of CETA solar training programs, particularly in the near-term. As noted, the solar industry is still emerging, even in states such as California that provide substantial financial incentives to purchase solar systems. A key strategy decision must be made in this environment: Should CETA training focus on solar jobs (and therefore provide broader, more in-depth training) or should the training provide general energy and construction skills with enough solar system knowledge to allow the graduate to move into solar work as opportunities expand? The first option is likely to provide greater assurance to consumers and the industry that solar systems are installed properly, but the cost may be borne by another set of consumers-the CETA participants who may be trained for jobs that do not exist. If the latter course is pursued, which seems preferable in most areas of the country at this time, criteria for assessing program effectiveness must recognize this broader emphasis on general skills.

Third, the roles of union and nonunion labor in the solar industry must be examined carefully if CETA programs are to be successful. In highly unionized areas, union opposition can render CETA efforts ineffective. Several solutions to this problem have been suggested. One is that CETA programs concentrate on providing students with basic construction skills at the preapprentice level. Such an arrangement would require a strong commitment from trade unions to ensure that apprenticeship programs are open to CETA 
graduates. A second alternative is for CETA programs to train students for retrofits on residential homes, while union labor would focus on commercial and new residential construction applications. At this stage, it is not clear how the solar industry will develop with respect to union or nonunion labor. Since solar installation requires several traditional trade skills, it is also uncertain how jurisdictions might be allocated among unions. The union/nonunion issue will not be a significant barrier for CETA programs in many. regions of the country, but in areas where unions are strong in construction trades, it will be necessary to define roles and allocate responsibilities to avoid conflict.

Finally, there are many federal, state, and local programs that have common purposesto reduce energy costs for low-income families and to provide marketable skills to unemployed individuals. Unfortunately, this commonality of purpose is rarely reflected in practice. Local solar training programs have to deal with several agencies to meet their program goals: prime sponsors and DOL for CETA funds; DOE, CSA, or HUD for weatherization and solar equipment purchases; and state/local employment agencies to assist in job placement. One way to reduce this duplication and confusion would be to combine funding sources for weatherization and solar system materials. This type of consolidation would also facilitate a more integrated and consistent approach to training individuals for the solar and conservation fields. 
SERI* 


\section{APPENDIX A}

\section{THE CALIFORNIA SOLAR EFFORT}

In response to the decreasing availability and increasing costs of conventional sources of energy, the State of California has made a major commitment to the development and commercialization of solar energy. With the support of Governor Brown, favorable solar legislation, and the establishment of state organizations responsible for expanding solar and alternative energy options, California hopes to attain the goal of 1.5 million homes and businesses served by solar energy by $1985[1$, p. 10$]$.

California's effort to commercialize solar energy involves a variety of activities. One major emphasis is the creation of a widespread demand for solar systems through public education and implementation of state solar incentives, particularly financial incentives that attempt to make solar applications economically competitive with conventional energy sources. Improving the state's job market through job development and training is another area of concentration.

A major step in the promotion of solar energy in California has been the implementation of the solar tax credit bill, which offers a homeowner a 55\% tax credit to a maximum of $\$ 3,000$ on the purchase and installation of a solar energy system. The bill also provides a tax credit of $25 \%$ or $\$ 3,000$, whichever is greater, for solar installations on commercial buildings where the costs are more than $\$ 6,000$. Other legislative actions include the establishment of the California Energy Commission's role in solar development; requirement of solar energy use, where feasible, in all new state buildings; and provision of interest-free loans for solar systems to disaster victims who are rebuilding their homes $[1$, p. 14].

Many agencies within the state government are active participants in the California solar effort. In 1978 two organizations, SolarCal and the Office of Appropriate Technology (OAT), were created to advance alternative energy technologies in environmentally sound, economically feasible, and socially enhancing ways.

SolarCal-established by Governor Brown on Sun Day, May 3, 1978-comprises the SolarCal Council and the SolarCal Office. The Council is made up of representatives from the solar industry, public interest groups, community groups, unions, utilities, and state and local governments. The Council's major concern is the rapid commercialization of solar technologies that are presently available, such as "water and pool heating; passive and active space conditioning for homes, offices, factories, and farms; industrial and agricultural process heat; and solar electricity" [1, p. 10]. The Council is the primary advisory board for the state in its effort to take full advantage of the economic, employment, and technology opportunities that solar energy offers. With heterogeneous representation from the public and private sectors, the Council also provides a "forum for public participation in state solar policy development" [2].

The Council advises the SolarCal Office, which is the "focal point within the state government for assisting the solar industry in the maximum feasible commercialization of solar energy" [1, p. 15]. The Office coordinates the solar energy activities of all state agencies, and acts as a liaison between the state government and the public on solar energy matters through public education, the implementation of state solar programs, and increasing the state's awareness of the needs of the solar industry, labor, and community groups [2]. 
The Office of Appropriate Technology provides technical assistance to other state agencies and educational groups. OAT has recently developed a statewide solar training curriculum designed to provide skills necessary for entry-level positions in the solar industry, completing the first phase of the CETA/OAT Solar Technology Training Program (STTP). The curriculum is available for use by community organizations, CETA prime sponsors, and other interested training or educational institutions [1, p. 16]. Phase II of the STTP Program establishes the Solar Work Institute, which will be responsible for assisting the various training agencies to implement the curriculum. This institute will also assist in developing effective training programs that will enable CETA-eligibles to obtain and retain gainful employment in the private sector. OAT also assists in the design of solar systems for state projects. It is presently developing a life-cycle cost formula for state solar projects and researching federal solar programs for applicability to state and local agencies.

The California Energy Commission is presently concentrating on "promoting solar water heating for new residential buildings, commercializing passive solar space conditioning in new residential buildings, and developing wind-generated electricity" $[1, p .15]$ as part of its three-year solar effort program. The Commission has also created the CAL SEAL label for installations. The CAL SEAL provides "the best assurance available that a solar system will qualify for the tax credit" [3, p. l].

Other state organizations active in the solar effort include:

- The Public Utilities Commission-requires utilities to offer incentives to end-use consumers of solar energy;

- The Office of the State Architect-designs and constructs new state office buildings to include passive and active solar heating and cooling;

- The Department of Consumer Affairs-offers various consumer protection services in solar areas;

- 'The Department of Housing and Community Development-administers interestfree loans of up to $\$ 2,000$ for solar systems to people rebuilding destroyed homes;

- The Department of Economic and Business Development-assists solar manufacturers with their plans for expansion, relocation, and marketing;

- The Employment Development Department-operates community solar action job development programs through its state and local CETA offices;

- The Department of Veterans' Affairs-handles mortgage loans to veterans which include the costs of solar systems in new home purchases [1, pp. 16, 17].

One component of California's solar programs and incentives is the CETA-funded training effort to supply the skills necessary for jobs created by the expansion of the solar industry. The CETA demonstration projects relate the needs of the low-income population to solar energy by not only providing CETA eligibles with marketable skills, but also providing low-income residences with solar systems (installations on low-income housing are part of the training process), protecting these people from the increasing costs of conventional energy sources. 


\section{REPERENCES}

1. Bartz, A.; Yudelson, J.; Lipton, R. (eds.) Toward a Solar California: The SolarCal Council Action Program. The State of California. January 1979.

2. Business and Transportation Agency, State of California. California: The Solar Capital. Information provided by the agency in mimeographed form. August 1978 .

3. California Energy Commission. "CAL SEAL Promotes Consumer Confidence." California Energy News: Special Solar Issue. May 1979; p. 1. 
SE가후 


\section{APPENDIX B}

\section{CALIFORNIA CETA SOLAR TRAINING PROGRAMS \\ INTERVIEW GUIDE}

\section{Program:}

Institution:

Type of Institution:

a. CETA Prime Sponsor

b. Community Development Center

c. Community College

d. College or University

e. Other

Name of Respondent:

Respondent's Connection to Program:

I. Program Description and History

1. How would you describe the objectives of this training program?

2. Is this a separate solar program, or part of a larger program such as a building construction program or a general heating and cooling program?

3. When was the planning for this program started? 
4. Who participated in the program planning?

5. When was the first course offered?

6. How many cycles of the program have been offered?

6a. How long is a course?

6b. How of ten is the course offered?

7. Have there been any major changes or modifications of any kind in the program since it began?

YES NO

7a. What were these changes?

7b. (for each change) Why was this change made?

8. What are the sources of funding for this program (distinguish CETA prime sponsor funds from Governor's discretionary funds, check for union or private industry funds)?

9. (for each source) What amount of funding has been provided to the program from this source? 
10. (alternate question) What portion of the program's funds come from each source?

\section{Program Participants}

1. What are the selection criteria for participants in this program?

2. What is the average number of students in each training program?

2a. Has this changed much over the life of the program?

2b. If so, how?

3. How many people have graduated to date from the program?

4. How many pëople have dropped out or not completed the program?

4a. Were there any particular differences among types of students with regard to not completing the course (for example, did more women than men leave the program)?

4b. Do you know what has happened to those who dropped out of the course? Did they enter other training programs, find jobs, or what? 
5. Would you describe the types of people who have been in the program, in terms of their general technical and educational levels, prior job experience, and their extent of interest in the solar aspect of the training?

\section{Program Content}

1. What $\%$ of the program is spent on teaching solar information and skills (as contrasted to general construction skills)?

2. What $\%$ of the program is spent on teaching basic job skills and job behavior?

3. What proportion of the student's time is spent in classroom sessions? In practical, hands-on experience?

4. Is the hands-on experience gained in a workshop, actual installations, or some other sotting?

4a. Would you describe the setting? 
5. Have you installed complete systems as part of the training?

YES NO

(for example, in local homes or businesses)

5a. What types of buildings were these installed on (e.g., low-income housing, commercial buildings, swimming pools)?

5b. What types of solar systems were installed?

Brief description (e.g., bread

Number

boxes, thermosiphon)

Domestic Hot water

Space Heating

Greenhouses

Other (specify)

5c. What were the arrangements for buying the equipment for these installations, and were the students paid for the installations?

5d. What arrangements were made for guaranteeing the solar system (components and/or installation)?

\section{Student Placement}

1. Do you keep track of your students after they leave the program?

YES NO

1a. (If yes) In what way? 
lb. Do you offer some type of placement assistance to your graduates? YES NO

1c. (If yes) What kind of assistance?

1d. What can you tell me about the students' placement rates and the types of jobs they are filling?

2. Do you know, or can you estimate, how many of your graduates are wurking in solar jobs?

3. What do you think are the major barriers to placing your students in solar jobs?

(If not mentioned, ask about transportation, discrimination against students, and availability of jobs in area for solar.)

4. How would you describe the local solar industry, in terms of number of jobs, stability, size of companies, chances for growth?

\section{v. Other Program Information}

1. What kinds of equipment do you use? Where do you get it? 
2. Do you provide tools and manuals for the student?

YES

NO

3. Do they become the property of the student?

4. Where do you locate (or recruit) your teachers/instructors?

5. Are the instructors full-time or part-time?

6. Are they all paid, or are there also unpaid volunteers?

$+\cdots$

$+$

7. How many instructors do you have for the program?

8. What qualifications do you look for in the instructors?

$=+r^{\prime}$

9. What types of credit or certificates are awarded the -students who complete the course?

10. What kinds of cooperation or interaction do you have with other local or regional training and employment programs? (CETA or otherwise)

11. What types of relationships do you have with local solar businesses? 
12. ... with local unions?

13. . . . with local educational institutions (e.g., community colleges)?

14. What, if any, general problems has the program encountered? Have shortages of equipment, trained instructors, and materials been a problem?

15. Has your program created any solar businesses as spinoffs?

YES NO

15a. If so, would you describe them?

Interviewer Instructions:

1. Ask to see copies of the materials/manuals used in the program. If copies are not available, at least get names of manuals and whether they were developed by the program.

2. Ask to see the workshop and to take pictures of the facilities and the test installations.

3. Ask if we could have copies of any program brochures or news clippings that provide additional information on the program. 
NAME

PROGRAM NAME

PROGRAM I.D.\#

SOCIAL SECURITY\#

I.D. NUMBER

Respondent address (include only if individual requested a copy of the final summary from the project). What would be the best mailing address for us to use?

(I.D. number is the code \# for the program and the last four digits of the Social Security number) 


\section{CALIPORNIA CETA SOLAR TRANIING PROGRAMS \\ GRADUATE INTRRVIEW GUIDE}

Please fill in from observation or from program records:

1. Sex:
a. Male
b. Temale
(circle answer)

2. Racial/Ethnic Group:
a. White
b. Black
c. Oriental
d. Am. Indian
e. Other

\section{READ TO PERSON BEING INTERVIEWED:}

As you were told when this interview was set up, the SolarCal Council here in Cahifornia is interviewing persons who have completed the CETA solar training programs. We want to find out what types of jobs they now have, whether they are using their solar energy training, and how they feel about the amount and kind of training they received. There are a number of particular things $\mathrm{Id}$ like to ask you, but feel free as we go along to make any other comments about the program or your experiences. The information from these interviews will only be used in a way that individuals and their responses cannot be identified. 
Before we talk about the program, Id like to ask you a few questions about yourself. We'd like to know what the background of the program graduates is.

3. How old are you?

4. (If person has a Spanish surname or heritage) Is your family originally MexicanAmerican, Puerto-Rican, Cuban, or other? (circle answer)
a. Mexican-American
b. Puerto-Rican
c. Cuban
d. Other

5. Are you married, single, or what? (circle answer)
a. married
b. single
c. widowed
d. divorced
e. separated

6. How many dependents do you have, including yourself? (Children, spouse, parents or other relatives that depend on you for nuel or all of their support.)

7. Up to the age of 16 , did you live mostly in a large city, the suburbs, a small town, or in a rural area (either on a farm or just out in the country)? (circle answer)
a. large city
b. suburbs
c. small town
d. rural area 
8. What is the highest grade you completed in school? (circle answer)
a. up through eighth grade
b. some high school
c. high school graduate
d. equivalency exam
e. post-high school (other than college)
f. some college
g. college degree

8a. (If the person had some post-high school training or college) What was the field of study and the name or type of institution?

8b. Did you get a degree? What was it?

9. Did you have any employment training before the CETA solar training program, such as training from employers, on-the-job training, job training in the military, a union apprenticeship or a trade school?
a. courses provided by employer
b. on-the-job training
c. trade or vocational-technical
d. school
e. military
f. junior or community college
g. apprenticeship
h. other (specify) 
9a. (If prior training) What types of training did you receive, for example, carpentry, or other building skills, plumbing or pipefitting?

9b. Have you participated in other CETA or WIN programs? (If so) what kinds and when?

10. How many different employers have you worked for since the age of 18 ?

(If they don't give a number) Could you give me an approximate number?

11. How many different kinds of work have you done since the age of 18 ?

(circle answer)
a. one
b. a few
c. several
d. many

lla. What kinds of work have you done?

12. What was the last job you had before the solar training program?

Now I'd like to ask you some questions about your experiences with the solar training program. 
13. How did you find out about the solar training program?

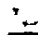

14. Why did you sign up for the program?

15. When did you complete the program (month and year)?

16. Id like to ask you how satisfied you were with some specific parts of the program. For each one, would you tell me whether you were very dissatisfied, dissatisfied, cannot decide (neither satisfied nor dissatisfied), satisfied, or very satisfied. If the particular thing was not included in your program, please tell me so. If you want to comment on any item, feel free to do so.

$\begin{array}{lllll} & \text { Very } & & \text { Can't } & \text { Very } \\ \text { How satisfied were you with: } & \text { Dis. } & \text { Dis. } & \text { Dec. Sat. . Sat. }\end{array}$

The feedback you got from your

trainers about your performance.

The way work was assigned during the workshop sessions. 
The amount of time you could .

spend with the instructors

The way job placements were

handled

The tools that were provided

The manuals that were provided

The way in which the tools and

manuals were provided to you

The program administration

in general

17. What else would you have liked out of the program?

One of the most important issues in our study is the type of jobs the program graduates are working in and whether they are using the solar skills. Id like to ask you some questions about your jobs since the training program, starting with your first job after the training program and ending with what you're doing now.

18. What was your first job after the training course?

18a. Did the training program help you get the job?

YES - NO 
18b. What type of business or company did you work for?

18c. Did (or does) the job involve solar energy?

YES

NO

18d. (If yes) What percent of time on the job involved solar energy?

18e. What was your job title?

18f. What were your job responsibilities?

18g. What types of skills did you use on the job? (e.g., carpentry, plumbing, writing, mathematics, salesmanship)?

18h. What was your initial salary (either hourly or weekly) when you first started the job?

18i. What was your top salary (either hourly or weekly) when you left the job (or current salary if still employed in this job)?

18j. How steady was this job? In other words, how many hours per week and weeks per month did you work at the job?

18k. How long were you employed in this job (weeks, months-specify)?

181. Are you still at that job?

\section{YES NO}

If YES go to question 20.

If NO go to question 19 .

19. Why did you leave that job? 
19a. What was your next job?

19b. What type of business or company did you work for?

19c. Did (or does) the job involve solar energy? $\quad$ YES $\quad$ NO

19d. (If yes) What percent of your time on the job involved solar energy?

19e. What was your job title?

19f. What were your job responsibilities?

19g. What types of skills did you use on the job?

19h. What was your initial salary (either hourly or weekly) when you first took the job?

19i. What was your top salary (either hourly or weekly) when you left the job (or current salary if still employed in this job)?

19j. How long were you employed in this job (weeks or months-specify)?

19k. Are you still at this job? . YES NO

If YES, go to question 20.

If NO, go to question 19-19-1 on additional sheets until you reach present job.

20. Have you worked on any solar installations since graduating from or leaving the program? YES NO 
20a. (If yes) How many solar installations since graduating have you worked on?

20b. How many of those were on separate houses?

20c. How many were larger, like on apartment houses or business buildings?

20d. What types of systems have you worked on (e.g., hot water, air)?

21. Do you feel that the training program adequately prepared you for the work you are doing"?

22. Have you worked with union members on any solar installations?

YES NO

23. Are you now in any way affiliated with a union?

YES $\cdot$ NO

23a. If so, which union?

I want to thank you again for talking to me about the program and your jobs. We're going to be writing up a summary of our project to send to people who have participated in the interviews. It will describe the various training programs and the overall job experiences of the graduates. Would you like us to send you a copy? 


\section{APPENDIX C}

\section{C-1. COMPREHENSIVE EMPLOYMENT AND TRANNNG ACT (CETA)}

The Comprehensive Employment and Training Act, signed into law on December 28, 1973, authorizes programs designed to provide training and employment services for "economically disadvantaged, unemployed, and underemployed persons." There are eight titles under CETA that establish and authorize specific activities and programs for eligible persons.

The primary purpose of the Act is to provide training and services leading to unsubsidized employment to increase the earned incomes and self-sufficiency of the disadvantaged. To obtain maximum efficiency in the procurement of employment opportunities, the Act establishes "a flexible, coordinated, and decentralized system of Federal, State, and local programs" [1, p. 19995]. Another objective of the Act is to provide for the coordination of programs under CETA with other social services, employment- and training-related programs, and economic- and community development-related programs.

The Secretary of Labor is responsible for providing financial assistance under CETA to qualified prime sponsors who administer the training and employment programs. Preapplications for Federal assistance must be submitted each year by applicants for prime sponsor designation, including those that have been designated prime sponsors in previous years. This preapplication qualifies applicants for all titles of CETA, except special grants to governors, which must be submitted separately.

The primary requirement under which a unit of general local government may qualify as a CETA prime sponsor is having a population of 100,000 or more [2, p. 19888]. A state, any consortium of units of general local government which includes a unit of general local government having a population of 100,000 or more, and the four existing Concentrated Employment Program (CEP) prime sponsors may also be designated prime sponsors [2, p. 19888]: Any unit of general local government or any consortium of such units, without regard to population, may be certified as prime sponsors if the Secretary of Labor determines that there is a need for such programs and that the unit is capable of effectively carrying out the program under the Act. In FY 1977, funding for the 445 prime sponsors totaled approximately $\$ 12.7$ billion [2].

Participants in the CETA program must be "citizens of the United States, United States nationals, permanent resident aliens, or other aliens who have been permitted to accept permanent employment in the United States by the Immigration and Naturalization Service" [4, p. 20001]. Eligibility determinations for each program are made at the time of application. Participants may be transferred from one title or program under the Act to another, if they meet the eligibility requirements of the program to which they are being transferred. Categories of eligibility include any person: "(1) who has been receiving unemployment compensation for 15 or more weeks; who is not eligible for unemployment benefits but has been unemployed for 15 or more weeks; who has exhausted unemployment compensation benefits; or who is, or whose family is, receiving Aid to Families with Dependent Children, and (2) who is not a member of a household with an adjusted gross income above $70 \%$ of the 'lower living standard income level' (established by the Bureau of Labor Statistics and adjusted for geographic region and families)" [1, p. 2000l]. Each title may contain additional requirements which are specific to that title. 


\section{C-2. THE COMPREHENSIVE EMPLOYMENT AND TRANNNG ACT OF 1973, AS AMENDED*}

Title I establishes a nationwide program of comprehensive employment and training services (including training, employment, counseling, testing, and placement) administered by prime sponsors, which, for the most part, are states and units of general local government of 100,000 or more population.

Title II authorizes a program of developmental transitional public service employment and other manpower services in areas with $6.5 \%$ or higher unemployment for 3 consecutive months.

Title III provides for nationally sponsored and supervised training, employment, and job placement programs for such special groups as youth, off enders, older workers, persons of limited English-speaking ability, Indians, migrant and seasonal farmworkers, and others with particular labor market diasdvantages. It also authorizes research, demonstration, and evaluation programs to be administered by the Secretary of Labor. In fiscal 1977, monies were provided under this title for such programs as the Skill Training Improvement Program, Help through Industry Retraining and Employment, and Demonstration Projects Act, except the Young Adult Conservation Corps.

Title IV authorizes the Job Corps, a program of intensive education, training, and counseling for disadvantaged youth, primarily in a residential setting.

Title $\mathrm{V}$ establishes a National Commission for Manpower Policy, an advisory group that has been assigned responsibilities for examining the nation's manpower needs and goals, advising the Secretary of Labor on national employment and training issues, and reporting its findings and recommendations to the President and the Congress.

Title VI authorizes a temporary emergency program of public service employment to help ease the impact of high unemployment.

Title VII contains general provisions, applicable to all titles, including definitions, conditions of work and training, prohibitions against discrimination and political activities, and administrative procedures for the orderly management of programs under the act.

Title VIII establishes the Young Adult Conservation Corps, which provides employment to youth who would not otherwise be productively employed. Participants are enrolled for a period of service during which they engage in useful conservation work and assist in completing other projects of a public nature on public lands and waters.

*Source: The Employment and Training Report of the President, transmitted to the Congress 1978. 


\section{REFERENCRS}

1. U.S. Department of Labor, Employment and Training Administration. "Comprehensive Employment and Training Act Regulations, Final Rule." Federal Register. Washington, D.C.: U.S. Government Printing Office. April 3, 1979; 1999020053.

2. U.S. Department of Labor, Employment and Training Administration. "Designation as "Prime Sponsor under the Comprehensive Employment and Training Act." Federal Register. Washington, D.C.: U.S. Government Printing Office. April 3, 1979; 1988819891 . 
SERI 


\section{APPENDIX D}

\section{JOB CATEGORY DEFINITIONS}

\section{PROFESSIONAL, TECHNICAL, AND MANAGERIAL OCCUPATIONS*}

This category includes occupations concerned with the theoretical and practical aspects of fields which include architecture; engineering; life sciences; social sciences; medicine and health; education; museum, library, and archival sciences; law; theology; the arts; recreation; administrative specialties; and management. Also included are occupations in support of scientists and engineers and other specialized activities such as piloting aircraft, operating radios, and directing the course of ships. Most of these occupations require substantial educational preparation, usually at the university, college, junior college, or technical institute level.

\section{CLERICAL OCCUPATIONS*}

This category includes occupations concerned with preparing, transcribing, systematizing, and preserving written communications and records; distributing information; and collecting accounts.

\section{SALES OCCUPATIONS*}

This category includes occupations concerned with influencing customers in favor of a commodity or service. Occupations closely identified with sales transactions are included even though they do not involve active participation in the transactions.

\section{SERVICE OCCUPATIONS*}

This category includes occupations concerned with providing domestic services in private households; preparing and serving food and drink in commercial, institutional, or other establishments; providing lodging and related services; providing grooming, cosmetic, and other personal and health care services for children and adults; maintaining and cleaning clothing and other wearing apparel; providing protection for people and property attending to the comfort or requests of patrons of amusement and recreation facilities; and performing cleaning and maintenance services to interiors of buildings.

\section{AGRICULTURAL, FISHERY, FORESTRY, AND RELATED OCCUPATIONS*}

This category includes occupations concerned with propagating, growing, caring for, and gathering plant and animal life and products; logging timber tracts; catching, hunting, and trapping animal life; and caring for parks, gardens, and grounds. Also included are occupations concerned with providing related support services. Excluded are occupations

*Asterisks indicate occupational categories from the U.S. Department of Labor Employment and Training Administration, Dictionary of Occupational Titles, Fourth Edition. Washington, D.C.: U.S. Government Printing Office, 1977. 
requiring a primary knowledge or involvement with technologies, such as processing, packaging, and stock checking, regardless of their industry designations:

\section{PROCESSING OCCUPATIONS*}

This category includes occupations concerned with refining, mixing, compounding, chemically treating, heat treating, or similarly working materials in solid, fluid, semifluid, or gaseous states to prepare them for use as basic materials, or stock for further manufacturing treatment, or for sale as finished products to commercial users. Knowledge of a process and adherence to formulas or other specifications are required to some degree. Vats, stills, ovens, furnaces, mixing machines, crushers, grinders, and related machines and equipment usually are involved.

\section{MACHINE TRADES OCCUPATIONS*}

This category includes occupations concerned with the operation of machines that cut, bore, mill, abrade, print, and similarly work such materials as metal, paper, wood, plastics, and stone. A worker's relationship to the machine is of primary importance. The more complicated jobs require an understanding of machine functions, blueprint reading, making mathematical computations, and exercising judgment to attain conformance to specifications. In other jobs eye and hand coordination may be the most significant factor: Installation, repair, and maintenance of machines and mechanical equipment and weaving, knitting, spinning, and similarly working textiles are included.

\section{BENCHWORK OCCUPATIONS*}

This category includes occupations concerned with using body members, handtools, and bench machines to fabricate, inspect, or repair relatively small products, such as jewelry, phonographs, light bulbs, musical instruments, tires, footwear, pottery, and garments. The work is usually performed at a set position or station in a mill, plant, or shop, at a bench, worktable, or conveyor. Workers in more complex jobs may be required to read blueprints, follow patterns, use a variety of handtools, and assume responsibility for meeting standards. Other jobs may only require workers to follow standardized procedures.

\section{STRUCTURAL WORK OCCUPATIONS*}

This category includes occupations concerned with fabricating, erecting, installing, paving, painting, and repairing structures and structural parts, such as bridges, buildings, roads, motor vehicles, cables, internal combustion engines, girders, plates, and frames. Generally, work is outside, except for factory production line occupations. The worker's relationship to handtools and power tools is more important than that to stationary machines, which are also used. Knowledge of the properties (stress, strain, durability, resistance) of the materials used (wood, metal, concrete, glass, clay) is of ten a requirement. 


\section{MISCELLANEOUS OCCUPATIONS}

This category includes occupations concerned with the transportation of people and cargo from one geographical location to another by various methods; with the packaging of materials and the moving of materials in and around establishments; with the extraction of minerals from the earth; with the production and distribution of utilities; with modeling for painters, sculptors, and photographers; with providing various production services in motion pictures and radio television broadcasting; with the production of graphic art work; and with other miscellaneous activities.

\section{UNSKILLED LABOR (NOT SPECIFIED)}

This category includes occupations requiring little or no special skills. Those in this category were nonspecified "unskilled labor" responses to the graduate questionnaire.

\section{FEDERALLY OR STATE FUNDED JOBS}

This category includes federally or state funded jobs or training programs for the economically disadvantaged.

\section{STUDENTS}

This category includes those respondents who were students at the college or junior college level.

\section{SOLAR ENERGY OCCUPATIONS (NOT SPECIPIED)}

This category includes occupations in solar energy that were not specified by the respondent.

\section{UNEMPLOYED}




\section{SE尺ㅋ.}




\section{APPBNDIX E}

\section{PROGRAM DESCRIPTIONS}

This appendix contains detailed descriptions of the CETA training programs included in the study. Each program description is organized into nine areas: (1) an introduction, (2) location and general facility description, (3) program description and history, (4) program content, (5) program participants, (6) student placement, (7) instruc tors, (8) interactions with outside organizations, and (9) problems. The introduction generally includes a brief description of the sponsoring organization and the nature of the program. The program description and history contains the objectives, how and when the program was initiated, length and frequency of the courses, changes or modifications since the program's inception, and funding. The course structure and form of instruction are described under program content. The section on program participants summarizes the type of students participating in the program, how they are selected, and the characteristics of those who do not complete the program. Besides stating the type of placement assistance offered to graduates, the student placement section describes the local conditions that influence the job market for the graduates. The relationships between outside organizations-other training programs, local solar businesses, local unions, and local educational institutions-and the programs are described under interactions with outside organizations. The last section presents some general problems that the program has encountered. Note that some of the program descriptions do not contain all the subtitles, either because they are not applicable to that program or because several kinds of information were combined under one subtitle.

Initial information for the programs was obtained through interviews, conducted in June 1979 , with the program directors. Since that time, mail correspondence with the programs and a conference involving program directors, SERI staff, and California government officials held in December 1979 have provided updated information for most of the programs. Except where noted, the program descriptions are based on their status as of December 1979.

\section{E.l THE FIRBOX SOLAR WATER HBATNG PROGRAM: KLAMATH RIVER CITZEN COUNCI* *}

\section{E.1.1 Introduction}

The Firebox Solar Water Heating Program is situated on the Hupa Indian Reservation in the mountains of northern Calif ornia. The area serviced is along the Klamath River from Pec wan to Weitchpec to Orleans. Half of this area is on the Hupa Indian Reservation Extension, the other half is off the official Reservation. The people in the total service area are primarily Yurok, Karok, and Caucasian.

In contrast to the other solar programs studied, this program does not have structured classes or required books, and all training is gained through practical experience. The program is coordinated by one person and receives funding for two students.

*Source: This information was obtained through an interview with the program coordinator at the time of the interview. 


\section{E.1.2 Program Deseription and History}

The primary objective of the program is to train students to install wood stoves, water heating systems, and solar water heating systems in area homes. Secondly, the program is providing low-cost water heating systems to Indian senior citizens. In doing so, the program hopes to encourage others in the community to adopt these technologies or other related technologies, such as greenhouse food dryers, by either installing one themselves, or paying others to do so.

The program is broken down into two phases. First, emphasis is on retrofitting wood stoves for heating water while heating the home during the winter, at relatively low cost. The equipment for retrofitting a wood stove costs between $\$ 40$ and $\$ 70$. The second phase involves the installation of solar water heating systems to supply hot water for the homes during the four months that the wood stove is not operating.

The program was conceived two years ago and a proposal was submitted through the Klamath River Citizen Council for CETA funding. The program was planned by the director with support from the Klamath River Citizen Council, the prime sponsor. The first session started in December 1978, with the installation of wood stove water heating systems.

Funding for the program was set for one year, with a 6-month extension. CETA funds $(\$ 16,000)$ were used to support two trainees. Presently, the project has one CETA position. The Bureau of Indian Affairs (BIA) funds the material and equipment used for the water heating installations. There is no definite limit for the BIA funding, which is obtained in increments for each house that is retrofitted. BIA funding for the solar water heating systems was received in August 1979. Equipment costs are expected to run from $\$ 120-\$ 150$ per home. There is no material funding yet for non-Indian senior citizens in the area.

\section{E.1.3 Program cioncent}

The training has focused predominantly on retrofitting wood stoves for water heating. However, since funding was secured from the BIA to do solar water heating systems for Native American homes, more training time will be spent on solar systems in the future. A large proportion of the time (7.0\%-80\%) is spent on teaching job skills and job behavior, particularly working with the homeowner and job responsibility. There are no formal classroom sessions. All training, about 20 hours per week, is accomplished through the actual installation of the wood stove water heating systems. The first year of the program was to include at least 35 installations on homes of people who are over 55 years old. There are no formal guarantees for the systems; however, project participants will perform repairs.

The equipment used includes pipes and water tanks, which are obtained from homeowners and plumbing stores. The instructor provides some of the tools. One of the students also owned tools which were used in the installations. The program itself does not provide tools or a certificate at completion. 


\section{E.1.4 Program Participants}

The only selection criteria for the participants is that they be CETA eligibles. No carpentry or plumbing skills are necessary, but a basic familiarity with tools is preferred. There were or iginally two students in the program. One was about 40 years old, and had prevlous training in machinery and welding in the armed services. He was also selftaught in auto mechanics. The other student was 23 years old and college educated. However, he had no particular tool skills at the start of the program. There is one instruc tor, who also serves as program director. He is not paid for either job.

\section{E.1.5 Student Placement}

There are not enough solar-related job opportunities in the community to offer full-time occupations to trainees. Most people in the area are on public assistance and do not work full time. Since not enough private business could be generated, public services would have to fund energy-related jobs in order to create an appreciable demand for solartrained people. However, there may be job possibilities in larger towns nearby for those individuals willing to move.

\section{E.1.6 Interaction with Outside Organization}

Because of its remote location, the program does not have much interaction with other training and employment programs. The closest solar training program is Net Energy, which is willing to share information, but is situated far enough away to make interaction difficult. The program has a good relationship with the local plumbing store, which has been very helpful in locating and supplying materials.

There is a Board of Directors for the program. The Board is made up of five elders whose major contribution has been moral support. This program has not created any new solar businesses.

\section{E.1.7 Problems}

A major problem encountered to date has been difficulties in locating some necessary materials, particularly $180^{\circ}$ galvanized pipe turns. It has also been a problem to find CETA-eligible individuals in the area who are interested in solar energy and who will participate reliably in the program. The lack of political, social, and financial support from the government and private sector for CETA programs in the area discourages many of the people who might consider solar energy training. 


\section{E.2 SOLAR TECHNICIAN TRAINING PROGRAM: NET ENERGY*}

\section{E.2.1. Introduction}

Net Energy is a private, nonprofit corporation within the educational-scientific classification. . Founded in the spring of 1977, Net Energy provides information and educational services and develops appropriate local and regional technologies in order to assist unemployed or low-income groups in the region. Since the fall of 1977, Net Energy has been the regional agency for the Emergency Energy Conservation Program, which provides insulation and weatherization to qualified low-income households. Net Energy is also a founding member of the Redwood Community Development Council and the Arcata Economic Development Corporation. It offered a 9-month course on solar technician training, which included workshops, classes at the College of the Redwoods, and on-the-job training.

\section{E.2.2 Location and General Facility Deseription}

Net Energy is located in downtown Arcata, approximately 12 miles from the College of the Redwoods. Facilities include a reference library, a workshop, and staff offices. Parking is available and there is easy access to the public transportation system.

\section{E.2.3 Program Description and History}

The Solar Technician Training program had four major purposes: training individuals in energy conservation and solar technology; assisting the community's economic development; demonstrating the feasibility of solar technology in the area by gathering performance data and establishing information on cost-effective systems; and helping the substantially une mployed or low-income groups with energy savings.

Net Energy, along with the prime sponsor (the Humboldt County CETA), began planning the program in the fall of 1978 in response to the request for proposals for the DOE/DOL/CSA Solar Utilization, Economic Development and Employment (SUEDE) Program. The course began on March 1, 1979, and the solar training program lasted 9 months.**

The sources of funding for the program were the CETA prime sponsor, the U.S. Department of Labor, and the U.S. Department of Energy. Fifty-five percent of the program's financing $(\$ 120,000)$ came from the CETA prime sponsor (Title VI funds). Fifteen percent $(\$ 32,000)$ was from the U.S. Department of Labor, and the remaining $30 \%(\$ 66,100)$ was from the U.S. Department of Energy.

*Source: This information was obtained through an interview with Kit Mann, the director for the Solar Technician Training Program, and brochures on Net Energy and their solar program.

**As of Dece mber 1979, the DOE/DOL/CSA SUEDE program was terminated. It should be noted that the decision to terminate was made before any results or evaluations of the SUEDE programs were available to the funding sources. 
The original proposal had planned on two quarters of classes at the College of the Redwoods and one quarter of on-the-job training. Because of delays in program funding, the curriculum was changed to one quarter of assigned classes and workshops, six months of on-the-job training, and nonassigned classes at the end of the cycle.

\section{B.2.4 Program Content}

The program spent about $60 \%$ of its instruction on solar information and skills, in contrast to general construction skills. Students spent one-quarter of total program time in classroom sessions, which were off ered three times a week for three months. The classes were held at the College of the Redwoods and included instructions on solar hot water heating, man and energy, and architectural drafting. The remaining three-quarters of the program was spent in practical training. The hours per week in formal instruction varied widely in different phases of the program; from 30 or more in the early phase to less than 10 in later phases, where much of the training involved practicing learned concepts or techniques (see Attachment E-1 for a listing of workshops and seminars). Instruction on basic job skills and job behavior was included in the program's job/career development training. The program was handled in a flexible manner, with workshops added as the need arose. Students were given the opportunity to evaluate the program monthly, and suggestions for changes were welcomed.

Textbooks were provided to the students. They included the Solar Energy Handbook Special California Edition; Natural Solar Architecture, A Passive Primer, by Wright; The Complete Greenhouse Book by Clegg and Watkins; Other Homes and Garbage by Leckie, Masters, Whitehouse, and Young; The Solar Home Book by Anderson and Riordan; and Do It Yourself Insulation and Weatherstripping and Homeowner's Guide to Solar Heating, both by Sunset. Hand tools and manuals were provided, and became the property of the students at the completion of the program.

The initial proposal contained arrangements for giving college credits to program graduates. However, because of funding delays, the graduates of this cycle were given certificates instead of credits. These certificates have no official standing.

Workshops and actual installations provided students with hands-on experience. During the training, complete systems were installed on low-income housing. The types of solar systems installed were domestic hot water systems, including 10 bread-box heaters and flat-plate collectors; 4-6 space heating systems, including air heaters and direct gain (with thermal mass); and 4-6 solar greenhouses and 4 attached greenhouses/solariums.

The material and components for the systems were financed by DOE. The ceiling for this funding was $\$ 1,500$ per system. Student stipends were paid through CETA funding. Guarantees for the systems rested up on the manufacturers of the components. Service or maintenance guarantees were limited to the funding period, although the staff has tried to continue maintenance service where possible.

\section{E.2.5 Program Participants}

The selection criteria for participants were that they be eligible for CETA programs, have an interest in solar and in a career in solar-related fields, have a minimum skill level, and have had high school algebra. The program had 16 students, 8 men and 8 women. The age breakdown was four students 19 years old, five between 20 and 25 years 
old; four between 25 and 30; and three over 30 years old. The class was primarily middle-class, white, with at least one year of college.

The students' educational background ranged from high school graduates through people with master's degrees. Most students had some familiarity with hand tools. Generally, the students had career interests in solar. However, some students seemed more interested in construction skills for their own use rather than for a solar career.

The first (only) cycle of SUEDE participants graduated on November 30, 1979. Of the two participants who did not complete the program, one left for a job in an unrelated field (music), and the other left to utilize his newly acquired contractor's license to design and build his first solar home. Of the 14 who completed the program, three have together started their own solar business, which is off to a good start in obtaining contracts; two are free-lancing weatherization and insulation work; one has received jobs installing DHW systems for hom eowners; one has obtained steady work in the construction trades; one will be developing and implementing a solar/alternate technology program for a community action agency in Oregon; one will be employed directly by Net Energy to monitor installations; three will return to school; and two will become part-time members of Net Energy's own design and consulting team.

\section{E.2.6 Student Placement}

Placement efforts were accomplished primarily through active job/career development training. These eff or ts emphasized training the participant in job search skills, goal definition, and selling themselves to potential employers or directly to clients. All local solar businesses, contractors, plumbers, and local municipalities were made aware of the availability of these trained people, but it was primarily up to the individuals to find their own jobs, with guidance and assistance from Net Energy and the College of the Redwoods' career center. Considering that the students were graduated at the beginning of the rainy season when the construction industry is at a low point, the placement results were very pleasing to the program director. The unfortunate timing of graduation resulted from initial funding delays.

During the program's operation, the local solar industry was characterized by a few solar installers and manufacturers. There was one solar store in Eureka, and three plumbing stores that carried collectors. There seemed to be only a moderate chance for job growth in the immediate area, particularly because the county is characterized by individuals who prefer to install their own systems rather than hire an outside company. There was also a general public skepticism about the feasibility and cost-effectiveness of solar energy. However, because of the program's efforts in demonstrating the feasibility of solar use to the public, which had a large part in increasing the relatively small local solar market, the program director feels that employment possibilities have improved considerably, especially for those interested in starting their own solar businesses.

\section{E.2.7 Instructors}

Instructors, besides those at the College of the Redwoods, were either trained in-house, or were local tradespeople. There were 5 part-time instructors for the program and 12-18 one-time speakers. The instruc tors included both paid workers and unpaid volunteers. Qualifications for these instructors included experience in the field they were teaching. Staff instructors possessed construction and plumbing skills as well as 
experience in design and construction of various solar systems. Instructors were also administrators and had organizational, planning, and managerial skills as well.

Some students also participated in training and supervision. There were four crew-leader trainees who had prior experience in construction or teaching. There was also a non-CETA supervisor responsible for the training activities of the program.

\section{B.2.8 Interaction with Outside Organizations}

The Net Energy solar program did not have much interaction with other training and employment programs in the area. It maintained good-but limited-relations with other SUEDE programs, and close interactions with both the local solar businesses and the College of the Redwoods. The program interacted with every solar supplier in the area (5), one manufacturer, and two distribution warehouses. The project advisory board included a solar contractor, the owner of a local solar business, a low-income senior citizen, a job developer from the community college, a professor, and a representative of Pacific Gas and Electric. There seemed to be no willingness on the part of the local unions to cooperate with the program. It should be noted, however, that the area is not heavily unionized. The program has created some spin-off solar businesses.

\section{E.2.9 Problems}

The major problem was funding delays, which made it difficult for the program to accomplish some of its original goals (such as obtaining credit for courses at College of the Redwoods). Another problem was the lack of full-time trained instructors or staff members. The program staff was expected to do administrative work in addition to planning, training, and instructing. Another apparent need was for acceptable certification of the program graduates, rather than certificates that have no official meaning within the industry. Discrepancies arose between production obligations and the need for more time to cover a particular subject area. The program administrators, however, felt that emphasis should have been placed on training, not on production.

Changes that would have been made if funding for the program were continued included better coordination of theory and hands-on experience through alternating the two; more structured workshops; the addition of classes in drafting, plumbing, and other construction skills from the College of the Redwoods; reduction of the required reading material for the course; and more attention to selecting trainees of the same skill level. 


\section{ATTACHMENT B-1 \\ NET ENERGY/SUEDE PROGRAM WORKSHOPS/SEMINARS}

Energy conservation-why bother?

Heat loss in buildings

Energy conservation in res. bldgs.

Weatherization techniques

Insulation, types, methods

Weatherstripping and caulking types, etc.

Weatherstripping and caulking practicum

Basic carpentry practicum-tool box

Basic carpentry-shop set up-benches

Basic carpentry-setting up equip., etc.

CSA/DOE Weatherization prog ram-background

The Weatherization site survey and for $\mathrm{ms}$

A ttic preparation for cellulose

insulation and use of blower machine

Glass and glazing-lecture and practice

Proper use of hand tools

Safety and first aid

In field weatherization

Natural gas appliances and trouble shooting

Proper use of power tools, includes radial arm saw

Carpentry practicum/outfitting vehicles

Slide shows/films - "Installing Solar and Passive Solar Energy, Natural Solar Heating and Cooling"

Heat loss recap

Customer relations

Outline of solar principles:

sun, spec trum, angles

greenhouse eff ect

transmissivity of glazings

thermal mass

fluid movem ent-convection

Local solar retrofit tour

$\begin{array}{ll}1 / 2 \text { day } & \text { in house } \\ 2 \text { days } & \text { in house } \\ 2 \text { days } & \text { in house } \\ 2 \text { days } & \text { in house } \\ 1 / 2 \text { day } & \text { in house } \\ 1 / 2 \text { day } & \text { in house } \\ 1 / 2 \text { day } & \text { in house } \\ 1 / 2 \text { day } & \text { in house } \\ 1 / 2 \text { day } & \text { in house } \\ 2 \text { days } & \text { in house } \\ 1 / 2 \text { day } & \text { in house } \\ 1 / 2 \text { day } & \text { in house }\end{array}$

1 day in house

$1 / 2$ day in house

$1 / 2$ day in house

1 day Red Cross Safety Course

many on job site - in-house teachers

1/2 day Pacific Gas \& Electric

1 day in house

$1-1 / 2$ days in house

$1 / 2$ day in house

1/2 day Pacific Gas \& Electric

$1 / 2$ day in house

1 day in house 
Solar greenhouses slide show (Net Energy) and lec ture

$1 / 2$ day in house

PG\&E energy conservation program and status of local nuclear plant

1/2 day Pacific Gas \& Electric

Direct gain retrofit systems and thermal mass lecture

$1 / 2$ day in house

Solar design-the human element

Resources-where to get information

1/2 day Jerry Lasell, architect

1/2 day Suzanne Guerra, Net Energy

Demand water heaters-theory and maintenance

1 day Craig Eilers, mfr. rep.

Sun Day Celebration: design displays, construc tion, public demo. - solar oven, parabolics, S-rotor wind machines, tank type $\mathrm{H}_{2} \mathrm{O}$ heaters

Films: Solar on the Farm-US ERDA Hamburger USA-Corporate/Socio/Political energy/resource wastage

Basics of concrete work

1/2 day Local contractor - Jon Vandermolen

Flat plate

1/2 day Local contractor

Mobile home construction

1/2 day. Payless Mobile Homes

Solar site evaluationsfactors to consider and practice

1 day in house

Mfr. rep.-Solar Energy Engineering collector and SDHW system

SDHW basics

Passive solar design

Tank-type SDHW systems design

Building codes/permits

1/2 day Joe Selby, rep.

1/2 day Local contractor

1 day Jon Stouman, architect

Flat-plate collector fablicution

$1 / 2$ day in house

1/2 day in house, Eric Johnson, Chief Building Inspector

1 day Al Johnson, welding instructor, College of the Redwoods

Conventional HVAC

$1 / 2$ day in house, George Lorenzo

Plumbing

$1 / 2$ day in house, Jim Kefler

Solar economics

Sun rights

1 hour per

topic,

System monitoring

in-house staff 
Solar air heaters

Wood heat

Photovoltaics

Wind power

Water power 


\section{E.3 THE SOLAR DEMONSTRATION PROJECT: LAKEVIEW EDUCATIONAL ASSOCIATION*}

\section{E.3.1 Introduction}

The Lakeview Educational Association (LEA) is a private, nonprofit organization. Through the Solar Dem onstration Project, LEA offered a training program which supplied students with the working knowledge necessary to assist in actual installations of solar systems. Classroom and workshop instruction were conduc ted in LEA's San Diego facility. The students received a CETA allowance equal to the current legal minimum wage in the state of Calif ornia. Applicants were screened for eligibility requirements by an authorized "Intake Agency" of the San Diego Regional Employment Training Consortium (RETC).

\section{E.3.2 Location and General Facility Deseription}

While the solar program was active, LEA was located in downtown San Diego near the airport. Facilities included staff offices, a library area, a 40-seat classroom, a workshop, equipment and materials storage, and a roof top solar system demonstration and testing area. The facilities were easily accessible by private auto and by the public transportation system.

\section{E.3.3 Program Description and History}

The main objective of the Solar Demonstration Project was to qualify and place participants in jobs in the solar industry. Other objectives, stemming from the newness of the industry, were to test the practicality of CETA solar training, and to utilize the attractiveness of solar energy as a motivator for CETA-eligible individuals to obtain and remain on a job.

Planning for the program started in the spring of 1978. Participants in the formulation of the program were the president of LEA, the proposed project administrator, several construction contractors who headed private firms, workers who had experience in solar installation, local elected public of ficials, a management consultant interested in solar energy, and the staff of the Regional Employment Training Consortium (RETC).

RETC, a CETA prime sponsor, was the main source of funding for this program. LEA's initial contract was $\$ 155,000$ for 9 months. Additional support in the for $m$ of equipment donations, amounting to less than $\$ 1,000$, came from the private sector. The first course was offered January 15, 1979. Classes were offered every 8 weeks. The Solar Demonstration Project lasted through three cycles.

After the program began, there were slight modifications in response to experience with the classes and concerns expressed by the prime sponsor (RETC). One program change was the development and implementation of stricter selection criteria. The program also

*Source: Information was obtained through an interview with Alan Hughes, the Administrator of the Solar Demonstration Project, and from the program brochures. On August 6, 1979, the RETC Policy Board denied a request for continuance of the program. : All activities ceased on September 30, 1979. 
increased the course time spent on teaching specific plumbing skills. Otherwise, the curriculum remained basically the same.

\section{E.3.4 Program Content}

The training program consisted of two parts: a 7-week period of instruction at LEA, and 8 weeks of on-the-job training. The solar course, entitled "Solar Systems-Installer Helper," was 7 weeks long (250 hours). It included classroom sessions (100 hours), workshops (70-80 hours), and field projects (70-80 hours). The field projects involved the ac tual installation of systems.

The breakdown of the course schedule was:

Orientation to Solar Theory

Tools and Work Safety

Solar Energy Collectors

Etorage of Solar Energy

Transfer Systems

Circulating Systems

Solai-Heated Swimming Pools

Total

\section{5 hours}

25

25

35

25

25

25

175 hours

Option I: Manufacture

Metal Working, Soldering,

Glazing-Painting, Inspection,

Testing, Packaging

Total Course I

Option II: Warehousing

Receiving, Inspection, Inventory Control, Material

Handling, Shipping, Invoicing

Total Course II

Option III: Installation

Work Order Procedures, Basic Pipefitting, Basic Carpentry, Basic Elec tricity, Soldering,

Testing, Landscaping

Total Course III

250

Students were expected to attend and be on time for all classes. Allowances were not made for missed classes. Students were rated either Pass, Fail, or Incomplete. Incomplete ratings could be cleared within 60 days following notification, or the rating was automatically changed to Fail. When all work had been rated Pass, the student was considered to have completed the course and received an appropriate certificate of 
completion. Only students receiving such certificates were eligible for placement assistance for the 8-week on-the-job training. A student could be dismissed from school for unsatisfactory attendance, failure to maintain progress toward completion, or for serious or repeated incidences of intoxicated or drugged behavior, possession of alcohol or illegal drugs on school premises, possession of dangerous or illegal weapons on school premises, behavior deemed likely to create a safety hazard to others in the school, or disobedient or disrespectful behavior toward other students, faculty, or administrators.

The students were provided with tools and manuals; about $\$ 40.00$ worth of these tools were given to the student if he or she graduated from the program. The graduates had the option of purchasing the remaining tools and manuals. The main book used was Solar Energy: Home Use in San Diego, by Dr. James K. Clinton. Additional material was provided as course handouts, and a library had additional books and reports available for the students. During the 7-week course, about two-thirds of the time was spent teaching general construction skills, and about one-third focused on teaching solar infor mation and solar skills. The program spent about $5 \%-10 \%$ of classroom time teaching basic job skills and job behavior.

Hands-on experience was gained through actual installation of systems during the first 7 weeks. Installations were completed at five different sites, including a flat-plate water heating system on the LEA building itself. Other settings were the La Jolla YMCA, the Medicine Wheel (a company next door to LEA), the Lutheran Center at San Diego State University, and a conference site in the mountains owned by LEA. The types of solar systems installed included one flat-plate domestic hot water heater, one bread-box water heater, two greenhouses at the community level, and one jacuzzi at the YMCA.

The components for these installations were paid for by the organizations for which the installations were constructed. The labor costs for these installations were included as part of the CETA stipend for the students. The program guaranteed the installation of the system until the end of the course cycle. The responsibility for the component guarantees rested with the manuf acturers of the components.

After completing the 7-week course, students were placed in an 8-week, on-the-job training position (totaling 320 hours) which paid them the normal wage rate for the particular job (\$3.50-4.50 per hour). The employer was reimbursed by LEA up to $\$ 1.75$ per hour as compensation for their training eff ort.

\section{E.3.5 Program Participants}

Selection criteria for participation in the first course were simply CETA eligibility and an interest in solar energy. Additional criteria were developed for later courses because of problems encountered with the range of student abilities, a large number of dropouts, and a limit on the number of students that could be handled by available facilities and finances.

Character istics required or preferred for selection into the program were: (1) familiarity and experience with tools, particularly plumbing and carpentry tools; (2) a practical interest in solar energy; (3) physical strength and agility (there could be no back or knee limitations for lifting and moving bulky objects; lifting up to $180 \mathrm{lb}$ was required at times); (4) no fear of heights, since much work is done on ladders and rooftops; (5) access to reliable transportation, due to the possibility of having job assignments 40 miles from home (a California driver's license was required, and a license to drive trucks preferred); 
(6) a willingness to do manual labor; and (7) a positive work attitude. LEA encouraged prospective enrollees to visit the classrooms and workshops and to discuss personal educational and occupational plans with the staff prior to enrolling.

Enrollment in the three cycles numbered 40, 20, and 12 students, respectively. A major characteristic of the students who participated in the program was a strong interest in solar energy. The majority also had some job experience in skilled manual labor, particularly in the carpentry and machinery fields. A sizable minority of students had advanced degrees; the median educational level was some college experience. Many of the successful students, however, were high school dropouts. Of the total enrollment, $20 \%-25 \%$ were women and approximately $25 \%$ were from minority groups. Out of the 60 students in the first two program cycles, approximately two-thirds (40 students) completed the course. Most of the dropouts (15) were from the first course, where limited selection criteria were used.

There were no particular differences among types of students who did not complete the course, except that child care was a problem for some women. A frequent reason for dropping out of the program was personality conflicts. There were no general patterns in reasons for dropping out of the course or in what the dropouts did afterward. Among the variety of paths taken were joining other programs, working for relatives, attempting to get jobs in solar energy and other areas, and remaining jobless.

\section{E.3.6 Student Placement}

LEA maintained an active place ment counselor. All students completing the course were offered the opportunity to participate in 8 weeks of on the-job-training. Students were also given job search assistance, resume help, and career counseling.

CETA contract requirements called for 30-, 90-, and 180-day follow-ups on students af ter they left the program. The student placement rate was slightly over $50 \%$. This included $40 \%$ who were placed in solar jobs, mostly as installers. The program administrator felt that the greatest barrier to placing students in solar jobs was the inability of the new industry to generate enough jobs. At the June 1979 activity level, he estimated that the solar industry would generate 50-100 jobs per year in the San Diego area. The industry, however, had not yet stabilized, so accurate predictions were difficult to make. Most solar companies in the area were small to middle-sized; few of them were more than a year old.

Other placement problems encountered included the need for graduates to have transportation to distant job sites. The government paperwork attached to an "on-the-job-training" program participant also discouraged private companies from taking trainees. There were also some difficulties encountered in placing women in solar jobs, since some companies were adverse to interviewing a female for construction work.

\section{E.3.7 Instructors}

The two full-time instruc tors were recruited locally from the construction industry. Visiting speakers and consultants were also used. The president of LEA also contributed time to the course without pay. LEA's primary concern in hiring instructors was competence and credibility in the topic area. Other characteristics sought were teaching ability and good communication and planning skills. 


\section{E.3.8 Interactions With Outside Organizations}

The program had very little interaction with other local or regional training and employment programs, or other educational institutions. It had some interaction with the University of California at San Diego in La Jolla. A UCSD professor wrote the text used in the course and spoke to the class. The program staff established a good working relationship with local solar businesses who cooperated with their on-the-job-training program. The only union that the program interacted with was the plumbers' union, because other unions in the area had conceded responsibility to them. The relationship was generally cooperative, although the official union position was that a good plumber is able to install a solar system with just 6 hours of instruction. However, the union put on demoristrations for the class, invited students to apply for apprenticeship training, and invited them to conferences. The program had an advisory board made up of four people: two union representatives, one from private industry, and one from education. They provided initial input and feedback.

There have not been any solar spin-off businesses to date. However, because of the interest in solar energy that was generated, people in the program were optimistic about businesses being created in the future.

\section{E.3.9 Problems}

The basic problems encountered by the program were generally bureaucratic ones. There were some negative feelings from those who didn't think the program necessary or who were uncomf ortable with the organizational character of LEA, including some staff and policy-level persons in the prime sponsor organization. There were also problems with contract compliance and cost requirements, particularly since the solar training programs were being judged by the same standards as conventional training even though solar costs were higher. The program director felt that these were the reasons why the RETC Policy Board denied a request for further funding of the program. 


\section{B.4 SOLAR ENERGY TECHNICIAN TRANING PROGRAM: CITY OF RICHMOND, MANPOWER SERVICE*}

\section{E.4.1 Program Description}

The Solar Energy Technician Training Program is sponsored by the City of Richmond (CETA Prime Sponsor) and directed by the City of Richmond's Manpower Service. Planning for the program was initiated in 1977. The first course began in June 1979. A Department of Labor competitive demonstration grant (STIP II) is funding the program at a level of $\$ 236,550$. Professional guidance is contributed by the Contra Costa Community College. The prime objective of the program is to produce trainees for entry-level positions in the local solar industry.

\section{E.4.2 Location and General Facility Description}

Classes are held at the Contra Costa Community College in San Pablo, California. The classroom is divided into two sections: one section is for lectures and demonstrations; the other, which is the major part of the classroom, is a laboratory for hands-on-training. There is also an asphalt area directly behind the facility which is used for storage space and outside lab work, such as building mock-up solar energy projects. The Staff Office is located within the classroom area. Students have access to a library on the college grounds, the services of a nurse in the Health Office, and the services of the counseling staff at the college.

\section{E.4.3 Program Content}

The curriculum for the course was developed in cooperation with the community college and an advisory panel from the local solar industry (see Attachment E-2 for a course outline). Classes are offered through the Contra Costa Community College for 12 months, and last 6 hours a day. Part of the course time is spent on theory, and the remaining time emphasizes hands-on experience through in-class workshops and on-the-job training. Approximately $60 \%$ of classroom time is spent on teaching solar information and skills in contrast to general construction skills. The program also spends some time teaching basic job skills and job behavior. The student, however, is expected to exhibit enough responsibility so that "hand-holding" will not be necessary. The program may try to obtain community development funding for installations of solar systems on lowincome housing during the training period. In addition to the 12-month training period, the program offers 6 months of on-the-job training with local private employers who are reimbursed by the program up to $50 \%$ of the trainees' salary as compensation for their training effort. It is hoped that this on-the-job training will open up permanent job opportunities for the trainees if the relationship between the trainees and employers is successful.

During the course of this first cycle, the program has been gaining recognition by the community. Contra Costa Community College has been so pleased with the students and their work that it has contracted with the program to solarize the swimming pool located

*Source: Information was obtained through an interview and correspondence with Cheryl Maier, the program planner. 
on college grounds. The program will also be taking part in a Department of Interior project, which would aff ord trainees the opportunity to design, construct, and install a solar system on a lighthouse off the coast of the Port of Richmond.

The equipment used by the program includes basic shop tools such as saws and plumbing equipment. Tools and manuals are provided and become the property of the students. (See Attachment E-3 for a list of the reading materials.) The participants are given college credits for the course work and some form of certificate is awarded upon completion of the program.

\section{E.4.4 Program Participants}

The major selection criterion for the program is that the participant be CETA eligible. Candidates were interviewed by the Community College for evidence of motivation and appropriate motor skills. Eighth-grade math and reading levels are required. The first course had 16 students.

Richmond has a very high unemployment rate and a large concentration of minorities. The program candidates are the "hard-core" unemployed, of which one-third are women. Before the program, most of the students did not have much knowledge of solar energy.

\section{E.4.5 Student Placement}

Career counseling and job hunting assistance is one of the prime objectives of the program. Placem ent assistance will be accomplished primarily through the on-the-job training contac ts with private employers.

The major barrier to placement currently seems to be a lack of solar jobs because the industry has been slow to develop in the local area. One reason for this slow development, according to local solar businesses, has been difficulty in finding trained solar workers. It is hoped that this training program will provide the solar installers necessary for the industry to expand. Due to favorable reactions by the community to the solar program, this solar industry barrier may be alleviated by the time the first cycle of students has graduated.

\section{E.4.6 Instruetors}

There is one full-time instructor, who is a plumber with experience in solar energy. The program has access to the faculty at the Community College for support courses. Arrangements have also been made to hire part-time instructors, if the need arises.

\section{R.4.7 Interactions with Outside Organizations}

The program has established close relationships with local solar businesses through the advisory board for the program (Solar Technical Advisory Council-STAC). STAC currently comprises eight members representing private local energy firms. Their occupational fields range from architects and planners to members of sunlight and power companies. Of the eight members of STAC, six of their firms are committed to considering successful program graduates for on-the-job training. 
Contra Costa Community College, where the classes are held, also participated in the program planning, supplying hands-on training opportunities to the students. Since most of the local solar firms are small and nonunion, no unions have been contacted to date. 


\section{ATTACHMENT E-2 \\ CONTRA COSTA COLLEGE \\ COURSE OUTLINE*}

SOLAR ENERGY

COURSE DESCRIPTION

Technical Instruction, beginning with knowledge of the trade, safety, related math, and basic processes.

\section{COURSE OBJECTIVES}

1. To instill attitudes and appreciations of safety.

2. To relate technical knowledge with job experience.

3. To instill attitudes and appreciations of good citizenship which contribute to continuous up-grading of craftsmen through cooperation with the school, management, and labor agencies.

4. To develop the ability to select, find reference to, and collect the resource material necessary to implement job processes.

\section{COURSE CONTENT}

1. Introduction

a. CETA orientation

b. College or ientation

c. Math and reading test

d. Math

e. Singer series of work stations
1) Eleztrical
2) Maintenance
3) Insulation

2. Carpentry
a. Safety
b. Tool identification
c. Materials of construction
d. Blueprint reading
e. Foundation and floors
f. Rough framing
g. Form detailing, construction, and erection

*This is the original course outline as of April 1979. Since then, it has been modified to cover-more solar-related equipment, such as pool covers, pool solar units, water heating solar units, solar wall construction, etc. 

h. Roofs
i. Exterior finish
j. Interior fin ish
k. Basic drywall application

3. Welding
a. Safety
b. Tool identification
c. Soldering
d. Oxyacetylene welding

\section{SOI.AR ENERGY}

4. Plumbing
a. Safety
b. Tool identification
c. Prineiples and practices of water supply and distribution
d. Principles of drainage and sewage disposal
e. Pipe and fittings measurements, the use of offsets
f. Materials used in construction of soil, waste, and vent systems
g. Drainage systems
h. Vent and venting systems
i. Traps
j. Domestic water distribution
k. Fuel gas piping, heating vents, and fuels
1. House sewers and private disposal systems

5. Solar installation
a. Safety
b. Tool identification
c. Type of units
d. Methods of installaton
e. Servicing

6. Sheet metal fabrication
a. Safety
b. Tool identification
c. Cutting methods
d. Brake, roller, and benders

7. Electrical and heating
a. Safety
b. Tool identification
c. Schematics
d. Basic electrical systems
e. Troubleshooting simple systems
f. Troubleshooting heating systems

\section{METHOD OF INSTRUCTION}

Lecture and demonstration 


\section{EVALUATON OF STUDENT PROGRESS}

1. Attendance, participation, and contribution

2. Topic tests

3. Manipulative lesson perfor mance

4. Unit tests 


\section{ATTACHMENT E-3 \\ CFTY OF RICHMOND, MANPOWER SERVICES SOLAR BOOK LIST*}

The Solar Book: Heating, Cooling and Designing with the Sun, by Bruce Anderson with Michael Riordan. Cheshire Books, Church Hill, Harrisville, NH 03450.

Solar for your Present Home (San Francisco Bay Area Edition) by Charles S. Barnaby, et al. Calif ornia State Energy Commission, Alternatives Implementation Division, 1111 Howe Avenue, Sacramento, CA 95825.

Sun Power: An Introduction to the Applications of Solar Energy, by J. C. McVeigh. Pergamon Press.

Solar Dwelling Design Concepts. Stock No. 023-000-00334-1, Superintendent of Documents, U.S. G.P.O., Washing ton, DC 20402.

The Food and Heat Producing Solar Greenhouse: Design, Construction, Operation by Rick Fisher and Bill Yanda. Bookpeople, 2940 Seventh Street, Berkeley, CA 94719.

An Inexpensive Economical Solar Heating System for Homes by Johnny W. Allred, et al. Langley Research Center Report NASA TM X-3294, from National Technical Information Service, Springfield, VA 2216.1.

Build Your Own Solar Water Heater by Florida Conservation Foundation, Inc., from: International Compendium, 10762 Tucker Street, Beltsville, MD 20705.

*Also included in the program, but not on this list, are mathematics and general construction reading materials. 


\section{E.5 SOLAR TECHNICLAN TRAINING PROGRAM: SKY RAY SYSTEMS, INC.*}

\section{B.5.1 Program Description and History}

The Solar Technician Training Program is funded by Alameda County CETA and conducted by Sky Ray Systems, Inc. The program's purpose is to provide participants with skills necessary for solar technician occupations, particularly installation. The program director also believes that an important objective is to develop strong work behavior and job motivation in the students.

Planning for the program began in November 1977. The program director developed the curriculum with the technical assistance of individuals from the local construction industry and Lawrence Livermore Laboratory. The CETA contract was received on August 2, 1978, and the first course cycle began on August 15, 1978. The course is 15 weeks long and is off ered every 17 weeks. Since the program began, there have been changes in personnel and in the course curriculum. Instructors are now considered more qualified to teach and organize a group of 13 students. To provide graduates with the ability to keep abreast of current and evolving solar installation techniques, more emphasis has been placed on basic technical skills, such as math, and on allied construction trades.

\section{E.5.2 Location and General Facility Description}

Sky Ray Systems is located in Hayward, Calif., and is housed in a portion of a former elementary school building. Facilities include office space, a classroom, and a workshop. The workshop contains equipment necessary to install domestic hot water and swimming pool systems. In addition, a yard area is used to construct various types of roof "mock-ups," on which collectors are installed as part of the training. The program also has a large van to transport students and materials to work sites.

\section{E.5.3 Program Content}

The program spends 6 hours a day, 5 days a week in training its students. The curriculum includes hot water heating systems, pool and space heating construction techniques, blueprint reading, solar theory, safety, and plumbing. Forty-five percent of program time is spent on teaching solar information, in contrast to general construction skills. Students are also provided with guidance in basic job skills and job behavior, which is emphasized about $15 \%$ of the program time. Students spend $35 \%$ of the time in classroom sessions, and $50 \%$ of the time in hands-on training.

Hands-on experience is gained in workshops and actual installations. Students are given construction assignments that involve building life-sized mock-ups of roofs, assembling solar equipment on the roofs, then dismantling the equipment. Complete systems have been installed on local homes, low-income housing, and swimming pools. To date, installations have included 7 domestic hot water systems (open and closed loop active systems and glazed panels), and active systems (glazed and unglazed panels) for swimming pools. All of the domestic systems were installed free of charge. A one-year written guarantee

*Source: Information was gained through a questionnaire completed by Gil Hyder, the program director, and an article in the July 1979 issue of Solarwork. 
for the system is provided to the recipients of the solar systems. Students also gain experience working with private companies on weekends.

Tools and reading materials are provided to the students. The basic textbook becomes the property of the student. The textbooks for the course are The Solar Home Book by Anderson and Riordan, and The Solar Decision Book by Montgomery and Budwick. Equipment purchased from local vendors and distributors includes lumber, tools, PVC, copper pipes, and collectors.

Students are awarded a certificate upon completion of the course.

\section{E.5.4 Program Participants}

In order to be eligible for the program, candidates must have been unemployed for 7 weeks and have earned an income less than the CETA eligibility criterion. The average number of students per course is 13. The candidates are handpicked by the program director. He selects the students on the philosophy that students learn as much from each other as they do from instructors. He tries to assemble a heterogeneous mix of students who hold potential for both individual and group achievement. The participants have generally had interests in ecology, particularly solar energy as a solution to environmental problems. The educational levels of the participants have ranged from high school dropouts to college graduates. Vocational characteristics have ranged from hardcore unemployed to those seeking a career change.

Through December 1979, 45 people had graduated from the program. There were two students who did not complete the course. One entered a solar training program in another county, and the other returned to his former institution for rehabilitation.

\section{E.5.5 Student Placement}

The program attempts to keep in contact with its graduates through phone calls and letters. An open house is held every course cycle; all former students are invited to attend the open house.

Placement assistance is provided through the program's contacts with local solar businesses. With the exception of students who returned to school, all graduates have been placed in jobs. Ninety percent ( 31 students) have been placed in solar energy-related jobs and the rest (besides those who returned to school) in construction jobs.

The local solar industry seems to have excellent chances for growth, particularly for companies that have the necessary capital and entrepreneurial expertise. However, there are barriers to placement of program graduates. The major problem has been in placing young female graduates because employers are apparently hesitant to give women construction-related jobs. Another barrier to placement has been the requirement of an excellent driving record. Local gasoline shortages also forced some graduates to relocate for employment. 


\section{E.5.6 Instruetors}

The eight part-time instructors for the program were recruited through the state employm ent office, the high school districts, and local junior colleges. Instructors are both paid and volunteer workers. Qualifications desired include the ability to teach both academic and vocational skills (such as carpentry and plumbing), and the ability to coordinate and organize a group of 13 students.

\section{B.5.7 Interactions with Outside Organizations}

Other training and employment programs have supported. Sky Ray in locating low-income housing for solar installations. They also have a good working relationship with local solar businesses. The program interacts with 22 separate solar companies, including manufacturers, distributors, and installers of solar systems. The program purchases materials and equipment from local solar companies who are enthusiastic about the availability of well-trained installers graduating from the program. The program has also established relationships with employers for students to work on weekends with the companies. Through this arrangem ent, students gain experience and receive pay at the same time.

Junior colleges have also supplied considerable assistance. The program director has tried to avert potential disputes with the unions by avoiding new construction jobs for the participants. Consequently, relationships with the unions have been positive. Some unions have extended invitations to graduates to participate in apprenticeship programs.

Businesses have been created as a result of the program; one graduate is establishing his own solar dealership in Canada.

There is also a three-person advisory board whose members come from the fields of education, finance, and graphic arts. They contribute to the program through job development, advice, and policy making.

\section{E.5.8 Problems and Planned Changes}

A problem encountered has been difficulty in finding trained instructors who are proficient in both teachirng skills and managing people. Another problem has been dealing with the necessary government paper work.

In the future, the program hopes to incorporate retrofitting schools and on-the-job training into its curriculum. The program director believes that by installing solar systems in conspicuous places, more people will be exposed to solar energy, thereby creating increased demand for solar systems. On-the-job training would last for 9 weeks, after 8 weeks of classiroom sessions. This would provide the students with experience in working for solar professionals, and gain skills readily useful to a solar company. 


\section{ATTACHMENT E-4 \\ SKY RAY SYSTEMS, INC.}

The fundam ental skills that are accomplished during the training are:

1. Carpentry.

2. Roof construction.

3. Sales.

4. Academics of solar theory, heating and air conditioning.

5. Pipe connections, sweating joints, brazing, soldering, and working with copper and PVC.

6. Estimating material and equipment needs for solar installations.

7. Insulation.

8. Elec trical skills to wire sensors, pumps, and control units.

9. Installations and servicing of swimming pools, domestic hot water systems, spas, and hot tubs.

10. Consultancy services.

11. Instruc tors.

12. Skills in working with others as a team.

13. Use of tools and equipment.

14. Responsibility to employer. 


\section{E.6 SOLAR/ENERGY TECHNICIAN TRANING PROGRAM: SONOMA STATE UNIVERSTYY*}

\section{B.6.1 Introduction}

The Solar/Energy Technician Training Program was offered through Sonoma State University. Compared with other CETA-funded solar programs in California, the Sonoma program was oriented more toward solar energy design and theory, and was geared toward training its students to be sizers, estimators, and calculations specialists, as opposed to installers.

\section{E.6.2 Location and General Facility Description}

The Solar/Energy Technician Training Program's office/workshop was located in the Alternative Energy Center building on the Sonoma State University campus. This small building was constructed specifically for the program by program participants, and contains many solar energy/conservation features and systems. Lecture classes were taught in classrooms at the University. Individual study and field experience courses required that the students visit solar installations in the Bay Area.

\section{E.6.3 Program Description and History}

The goal of the program was to train individuals as solar technicians (as opposed to installers). Planning for the program began in 1976 when the State of California became interested in funding solar training programs. The former director of the program, who had just graduated from Sonoma State University at that time, wrote the proposal that received the program grant from the Governor's discretionary CETA fund.

The first training cycle began in the fall of 1976. The third and last training cycle ended in September 1979. Approximately 16 participants received training each year.

The first cycle was funded by the Governor's discretionary funds $(\$ 90,000)$. The last two cycles were funded by the local prime sponsor, Sonoma County $(\$ 160,000 / \mathrm{yr})$.

Courses were added during the three years in response to feedback from local solar employers. Courses added included instruction in use of the F-chart (simulation program used for system optimization), programming, blueprint reading, and instructions in building code compliance calculations.

\section{E.6.4 Program Content}

Instruction on solar energy theory and applications took up $60 \%$ of course time. The program also emphasized mathematical and technical areas such as trigonometry, programming, and blueprint reading. Approximately $20 \%$ of the program was spent on teaching basic job skills and job behavior, including job-seeking skills. The courses were primarily oriented toward solar energy theory and design; $80 \%$ of the time was spent in the

*Source: This information was obtained through an interview with Gayla Tyson, the Job Developer and Administrator of the program. 
classroom, compared with $20 \%$ on hands-on experience (see Attachment E-5). The students spent approximately 11 hours per week in the classroom each semester. For each hour they spent in class, they were responsible for 2 hours of homework weekly. In addition, a 90-hour individual project was required each semester, on which they spent about 6 hours weekly. On-the-job training amounted to roughly 2 hours per week.

Most of the reading materials were written and/or compiled from various sources by the program's director and instructor, mimeographed, and handed out to the students. (See Attachment E-6 for a list of reading materials used during the course.) There was not an extensive amount of equipment because of the emphasis on design and sizing rather than installation. The students were given $\$ 200.00$ to purchase tools. Included in their choice of items were programmable calculators and hand tools which became the property of the student upon completion of the program. Students were also granted between 15 to 29 college credits, and a certificate was awarded for those who passed the final examination.

Hands-on experience was gained through actual installations on the Alternative Energy Center building and through individual student projects. The types of solar systems installed on the training building were two domestic hot water systems (one active and one bread box) and three space heating systems which included one air system and two water systems (a trickle down and a copper-on-copper). The building itself, constructed by the students, is passive in design. A nonattached greenhouse was also built. The training materials were funded from the CETA grant, and the building materials were all donated.

\section{E.6.5 Program Participants}

In the first year, out of 200 applicants, 15 students were selected for the program. After CETA screening, the selection process started out with a high-school level algebra exam. Only those who passed this exam were interviewed for further screening. Through the interview, those that exhibited an interest in solar energy and were above a minimum level of capability were selected. The last cycle contained 16 students.

In the first two years, all 31 students who entered the program completed the training course. However, there were some who did not pass the final exam. In the last cycle, there was one dropout, probably due to a lack of sufficient basic education. That person was a high school dropout and is now back in school to gain the necessary background education.

Many of the students have had some college education and were highly educated relative to most CETA-eligibles. Some had construction experience and all were generally enthusiastic about solar energy.

\section{E.6.6 Student Placement}

The program had an impressive $100 \%$ graduate placement rate. Of those that can be located, all are in solar-related jobs. The solar industry in the area has expanded rapidly in the last few months, and is expected to provide additional jobs in the future.

The program tracked its students through personal contacts. There was also a "hotline" available for those contributing information on solar opportunities. Place ment assistance 
was provided by a half-time job developer who gave the students extensive counseling and career instruction. Constant contact with solar employers was also kept. Graduates were placed throughout the state and nation, not just in the surrounding area.

\section{B.6.7 Instrue tors}

Besides the program director, there were four part-time instructors for the program. The part-time instructors were Sonoma State University faculty members who taught nonsolar support courses such as math and computer programming. The program director taught the solar energy courses, and has considerable background in solar energy. All instructors were paid for their participation in the program.

\section{E.6.8 Interaction with Outside Organizations}

The program generally maintained good relations with the CETA prime sponsor. One problem occurred when the prime sponsor felt that the algebra exam, used for prescreening, discriminated against minorities and hard-core unemployed people. However, this dispute was resolved. The program administrator also met with all other CETA job developers in the county every month.

There was a strong relationship with local solar businesses, to the point that some firms would call the program whenever there was a job opening. Although contacts with local unions were limited, no problems were encountered. There was very little interaction with other local educational institutions.

Several of the program graduates have started their own solar companies. A nonprofit organization also may be created as a result of the program.

\section{E.6.9 Problems}

The greatest problem was trying to maintain a high-quality, effective program under the auspices of two different organizations-the University and CETA. Program managers found it very difficult to function under two different sets of rules, orientations, and objectives. The University did not provide much support, primarily because of perceived bias among University administrators toward liberal arts rather than vocational/ technical education. Although CETA viewed the program as highly successful, the prime sponsor was not considered to be strongly supportive of program efforts. Another problem was obtaining funds for equipment and materials.

Partially because of these problems, and a desire on the part of program administrators to transfer their energies into other areas, the program was discontinued in September 1979 , to the disappointment of the prime sponsor. 


\title{
ATTACHMENT E-5 \\ SONOMA STATE UNIVERSTTY \\ CLASSROOM AND ON-THE-JOB TRAINING DESCRIPTIONS SOLAR/ENERGY TECHNICIAN TRANNING PROGRAM
}

\begin{abstract}
FALL SEMESTER
Environmental Studies 337. Solar Energy, Direct Uses. 3 units.

An introduction to the design of active and passive solar heating systems, collector and system efficiencies, construction techniques, selective surfaces and glazing, distribution and storage systems for use in solar space heating, domestic hot water, and swimming pools. Climatology, heat loss and flow rate calculations, advantages of different types of insulation, heat pumps, shading devices and control systems.
\end{abstract}

Environmental Studies 337d. Independent Studies in Solar Energy. 2 units.

Students study in groups or individually a problem or type of device that is relevant to their interests. Examples are: water turbines, grant writing, solar greenhouses, testing of commercial solar collectors, studies on commercial and private structures, wind genera tors, and methane digesters.

Physies 210. General Physics. 3 units.

Includes, besides descriptive physics, an explanation of mechanics, thermodynamics, hydronics, vec tors.

Math 107. Algebra and Trigonometry. 4 units.

Class or iented toward practical applications. Utilizing HP33E calculators, students receive a comprehensive coverage of algebra, trigonometry, and an introduction to analytical geometry, essential to an understanding of solar angles and insolation.

\section{SPRING SEMESTER}

Environmental Studies 437. Advanced Solar Energy Seminar. 3 units.

Advanced theory of passive systems, orientation, trigonometry of awnings, life-cycle costing, F-chart method, and troubleshooting.

Environmental Studies 337d. Independent Studies.. 4 units.

Same as Fall. 
Computer Programming. Basic +. 1 unit.

Students learn method of programming mathematical calculations essential to feasibility studies and payback periods.

Elective. 3 or more units.

Each student selects a course valuable to him/her in particular areas of specialization. Examples are: "Energy, Education and the Environment," "Planning Media and Architectural Drafting," "Introductory Optics," "Electronics," "Biology and Energy," "Energy, Ecology, Economy," and "Small Rural Community Development." Work internships can be substituted:

Management 35 1. Managing The Small Business. 3 units.

This class will cover market research, selling, management functions. Use of time, records controls, and insurance. Public relations, personnel, and successful business traits,

\section{Architec ture And Energy.}

Blueprint reading, Title 24 compliance calculations, integration of solar and energy efficient design into mainstream housing market.

\section{SUMMER}

Solar Energy Technology Field Experience. 3 units.

Field trips to solar installations in the Bay Area. Students will build solar collectors and practice sizing and installation. They will develop complete materials lists and cost estimates.

\section{Solar Energy Theory And Applications, A Review. 2 units.}

Total review of the theory and practical problems of solar energy devices. Consumer protec tion and relations with clients. Analysis of all systems built during training.

Certification of trainees will be preceded by an intensive and thorough final examination covering all aspects of energy training. 


\section{ATTACHMENT E-6 \\ SONOMA STATE UNIVERSTYY \\ TEXTS USED DURING SOLAR/ENERGY TECHNICIAN TRANING PROGRAM, 1976-1979}

Other Homes And Garbage. 1975. Lecki, Masters, Whitehouse, \& Young; Sierra Club Books.

College Physics, 4th Edition. 1974. Zemansky and Young; Addison-Wesley.

Small Business Management, A Practical Approach. 1977. Sullivan; William C. Brown, Publisher.

Solar Heating Design By the F-Chart Method. 1977. Beckman, Klein, \& Duffie; John Wiley and Sons.

There are countless other good books available on solar energy and related topics. The following are supplemental reading materials.

\section{Nontechnical}

Designing and Building A Solar House. 19\%\%. U. Watson; Garden Way Publishing. Low-Cost Energy-Efficient Shelter for the Owner and Builder. 1976. E. Eccli (ed.); Rodale Press.

The Passive Solar Book (paperback). 1978. Ed Mazria; Rodale Press.

Soft Energy Paths: Towards A Durable Peace. 1977. A. R. Lovins; Ballinger Publishing Company.

Solar Dwelling Design Concepts. 1976. AIA Research Group for Department of Housing and Urban Development (HUD); U.S. Government S tock \# 023-000-00334-1.

Sun/Earth. 1977. Crowther; Crowther/Solar Group.

Sunspots. .1977. Steve Baer; Zomeworks Corporation.

Village Homes' Solar House Design. 1979. Bainbridge, Corbett, Hofacre; Rodale Press.

National Solar Heating and Cooling Inf ormation Center, P.O. Box 1706, Rockville, Maryland 20850 (800) 523-2929, has a considerable number of free publications, both technical and nontechnical, aimed toward the consumer.

\section{Technical}

Energy Conservation Design Manual for New'Residential Buildings. 1978. State of California, Energy Resources Conservation and Development Commission, Conservation Division, 1111 Howe Avenue, Sacramento, California 95825.

Engineer's Guide to Solar Energy. 1979. Howell \& Berry, Solar Information Services, P.O. Box 204, San Mateo, California 9440 l.

A Guide to Federal Programs of Possible Assistance to the Solar Energy Community. 1976. Congressional Subcommittee on Science and Technology, U.S. Government Printing Office. 
The Passive Solar Book, Professional Version (hardbound). 1979. Ed Mazria; Rodale Press.

Proceedings of the Third National Passive Solar Conference. 1979. Proceedings of the Second National Passive Solar Conference. 1978. Publishing of fice of the American Section of the International Solar Energy Society, Inc., McDowell Hall, University of Delaware, Newark, Delaware.

Computer

Basic Computer Programming. Dick Giles, Santa Rosa Junior College Bookstore.

Basic Basic and Advanced Basic. 1970-1978. Coan; Hayden Book Company. 


\section{E.7 SOLAR TRANING AND UTHLATION: COMMUNITY RESOURCE PROJECT, INC.*}

\section{E.7.1 Introduction}

The Solar Training and Utilization Program is part of the Manpower Training Unit of the Community Resource Project, Inc. The Community Resource Project, Inc., is involved in providing social and educational services, manpower training, and job placement for CETA-eligible people in the Sacramento community. The Manpower Training Unit is responsible for placing their clients into training programs that would best complement the person's interests and capabilities. The programs include on-the-job training, work experience, and classroom instruc tions geared toward providing skills and job motivation that would better qualify clients for permanent, meaningful jobs. The Unit is also responsible for locating jobs, job development, and placement.

\section{E.7.2 Location and General Facility Description}

The Community Resource Project's facilities includes offices, classrooms; an enclosed small tools storage room, and a large workshop area. The workshop functions as a handson training station for the construction of solar systems, and as a large-equipment storage area.

\section{E.7.3 Program Description and History}

The objective of the Solar Training and Utilization Program is to produce high quality solar technicians and to retrofit low-income homes with solar systems. The funding for the program from the CETA prime sponsor is presently for 6 months of classroom work, followed by 3 months of on-the-job training, at the level of $\$ 78,500$.

Planning for the program started in February 1977 by CRP, Inc., with the assistance of consultants from the local university. It took two years for funding to be approved after applications for a number of earlier funding opportunities had been refused. CRP, Inc., is presently in the process of submitting a proposal for a weatherization program in addition to the solar program.

The first course was off ered on April 16, 1979. The course continued for 6 months, after which students participated in 3 months of on-the-job training. The frequency of course offerings will be contingent upon future funding.

\section{E.7.4 Program Content}

The program has adopted the curriculum developed by the Office of Appropriate Technology (OAT). This 6-month curriculum was designed for use with groups of approximately 10 people who have had no prior education or training in any solar-related fields. It is divided into two modules; one is an introduction to solar energy theory, and the

*Source: Information was obtained through an interview with Maria Castro, the Director of CRP, Inc., a brochure on CRP, Inc., and an article in Solarwork. 
other covers practical skills building. The skills module is further divided into three sections: Solar Water Heating, Solar Hydronic Space Heating, and Solar Pool Heating. The program also emphasizes basic plumbing skills.

The solar theory section of the course is taught as part of the Continuing Education Program of Sacramento State University. This part of the program, which is held in house, continues for 7 weeks with exams given once a week.

Practical experience is gained in workshops and through 3 months of on-the-job training that clients participate in after completion of the 6-month curriculum. During the first cycle, students working in teams retrofitted low-income homes, built and installed four domestic hot water systems, two greenhouses, and one active flat-plate heating system.

\section{E.7.5 Program Participants}

CRP, Inc., conducts extensive outreach recruitment for its solar program from other local community-based organizations. For the first course cycle, there were 150 applicants, from which 10 were chosen. In order to qualify for selection, candidates must be CETA eligible, possess reading and writing skills up to the 9 th-grade level, and have basic math skills. The program targets its selection toward certain groups of people: Vietnam-era veterans, ex-offenders, women, and youths. For the first course, the participants chosen were all highly motivated and had basic carpentry skills.

On October 1, 1979, the program graduated 9 participants from an original class of 10 trainees. The one drop out is currently employed in an allied trade on a full-time basis. of the 9 graduates, 7 have been employed in on-the-job-training positions within the solar industry, which eventually will be transformed into permanent job positions. One graduate is currently being considered for a position in the solar field, and the other is enrolled in school on a full-time basis.

\section{E.7.6 Student Placement}

The goal of the program is to place at least $60 \%$ of its graduates into solar jobs. On-thejob training is the program's main avenue for job opportunities. Also, there is optim ism that the solar industry will blossom in the Sacramento area in the near future.

\section{E.7.7 Instructors}

The program has a Master 'I'rainer/Coordinator. 'I'his person is supported by part-time consultant craftspersons whose areas of expertise are in fields such as carpentry, electrical work, and plumbing.

\section{E.7.8 Interaction With Outside Organizations}

There is good cooperation with the local solar businesses. Interactions with the local educational institutions have been positive and helpful. Consultants from these institutions helped with the technical aspects of the program's proposal. CRP, Inc., also interacts with other local community-based organizations for recruitment purposes. The program hopes small businesses will be created as a result of the course. 


\section{E.7.9 Problems}

The main problem was the lack of sufficient funds for facilities and equipment. Another expressed concern has been the selection of appropriate candidates. The Master Trainer/Coordinator feels that the main selection criterion should be a consistent proficiency level for those selected, regardless of the absolute level of their skills. 


\section{E.8 SOLAR ENERGY PROJECT: SAN MATEO ECONOMIC OPPORTUNITY CORPORATION*}

\section{B.8.1 Program Description}

The Solar Energy Project, sponsored by the San Mateo Economic Opportunity Corporation, is funded by CETA (County of San Mateo Prime Sponsor) and the National Center for Appropriate Technology (NCAT). CETA's contribution is $\$ 10,000$. NCAT will finance the installation of solar energy systems on low-income houses up to $\$ 5,000$.

Planning for the program was initiated in July 1977. It was first submitted as a SUEDE proposal, but did not receive the grant. The first course was offered in January 1979. The first-cycle course lasted for six months and will be offered on a yearly basis. The purpose of the project is to offer solar technician training in a pructical setting.

\section{E.8.2. Location and General Facility Description}

Lecture courses are offered at the local community college and at the EOC office in San Mateo. Hands-on experience is gained by working on the Solar House, which is located in East Palo Alto. During the first course, the Solar House was built (earlier projects had constructed the shell) and a greenhouse and a domestic hot water system were installed.

\section{E.8.3 Program Content}

The program spends about $40 \%$ of its time teaching solar information and skills in contrast to general construction skills. Approximately $10 \%$ of the time involves instruction in basic job skills and job behavior. Class sessions, which total 15 hours per week, are given at both the San Mateo EOC office and at Canada Community College. Canada Community College off ers 8 hours (two classes) of support courses such as architectual design and environmental studies. The remaining hours (two classes) at the San Mateo EOC office are spent specifically on solar energy.

Hands-on experience is gained through actual installations and on-the-job training with local solar companies. The program spends 25 hours per week on this practical experience. During this cycle, the class has built a complete solar house, which includes a domestic hot water system and a greenhouse. The students work from 10-12 hours a week (including weekends) with private companies installing solar systems, primarily hot tub and swimming pool applications.

The NCAT grant allows for the installation of three active domestic hot water systems on low-income housing. The Solar House was financed from various sources, including revenue sharing from the county and HUD grants. Five-year warranties will be offered through a local solar company for the three domestic hot water systems.

The textbook used for the course is Designing and Building a Solar House by Donald Watson. The equipment used is supplied by local solar companies. The basic tools

*Source: Information was obtained through an interview with Bill Thane, the Solar House Director. The description is based on the status of the training program as of July 1979; updated information on the program was not available. 
are paid for by CETA. Tools and manuals are provided and become the property of the student. Students are awarded five community college credits and a certificate upon completion of the program.

\section{E.8.4 Program Participants}

The selection criteria for the program are that the candidates have a basic knowledge of tools and an interest in solar energy. There were five students in the first course cycle. Two of the students were placed in jobs before the course was finished and the others graduated in July 1979. There have been no drop outs. All the participants had been unemployed for at least a year before entering the program. One person had some plumbing experience before entering the program, while the other students had little or no construe tion backg round.

\section{E.8.5 Student Placement}

The program will keep track of its graduates for 18 months after completion of the course. Placement assistance is provided primarily through contacts with the local solar companies. The program feels that its emphasis on basic skills, as opposed to theory, will make it easy to place students, particularly since the local industry has been expanding rapidly in the last few months.

\section{E.8.6 Instructors}

There is one full-time paid instructor for the program. The instructor has had extensive experience in solar energy and weatherization. Instruction is also given through the community college for the support classes.

\section{E.8.7 Interaction with Outside Organizations}

Students attended a 3-day greenhouse workshop sponsored by Farralones Institute. They are also enrolled in courses at the local community college. It is felt that relationships with local solar businesses that provide students with on-the-job training are strong. The plumbers' union has expressed an interest in hiring graduates for their apprenticeship program.

\section{E.8.8 Problems}

The cost of materials and equipment was one of the problems the program encountered. Program personnel also recommend conservatism in terms of the number of projects offered and the extent of training that can be provided in a relatively short period of time. 


\section{G.9 SOLAR TRANING PROGRAM: PROTEUS ADULT TRAINING, INC.*}

\section{E.9.1 Introduction}

The Solar Training Program is offered through Proteus Adult Training, Inc., a private nonprofit organization. Proteus serves a rural, low-income clientele consisting primarily of farm workers. Its employment and training program is geared toward teaching skills necessary for practical job placement.

\section{E.9.2 Location and General Facility Description}

The Solar Training Program is housed in the Skill Training Center located in Hanford, about one-half mile from Proteus' general office. The facility has a workshop, instructors, offices, and classroom space. The workshop is equipped with the basic tools (workbenches, saws, drills, wrenches, etc.) necessary to construct bread-box water heaters and install active water heating systems. The building also has an outside fenced-in area which is used for constructing solar systems and for the storage of equipment and materials. This large storage area enables the program to order its materials in bulk.

\section{E.9.3 Program Description and History}

The primary objective of the program during its first year was to train students to become retrofit installers (primarily hot water systems). Through this training, the students learned the basics of plumbing and allied construction skills. Another goal was to provide a community service by making solar systems accessible to low-income families and to offer community education and consumer awareness about solar energy. To demonstrate the feasibility of solar energy systems in the area, data on the performance of the systems installed under the program will be used as part of a community education program.

Planning for the solar training program began in mid-1977. The first class was held on February 15, 1978, starting with ten students. After six months of training, five students graduated. The remaining five students were retained for an additional six months of training, and five new students were added at this time. The program is presently in its eecond cycle, and is now six montlis long for all students.

*Source: Information was obtained through interviews with George Schultz, a former . instructor in the program; Herman Perez, the Regional Director for Proteus; and a brochure on Proteus. 
The program is funded by CETA and the Community Services Administration (CSA). The initial funding proportion was 50\% CETA from the Governor's discretionary funds and $50 \%$ from the CSA, for a total of $\$ 300,000$. Presently, CETA is the primary source of funds. It finances the wages and salaries for participants, trainers, and administrators. CSA is currently contributing funds for equipment and materials. CSA is also the source of a $\$ 42,000$ energy conservation grant.

There have been other modifications made since the completion of the first cycle. The course presently combines instruction on solar energy with weatherization. Training for the first class emphasized solar energy installation as opposed to basic construction skills. Now, plumbing is stressed and instruction on solar-specific skills has become secondary. The reason for this switch is that the majority of skills needed for solar installation appear to be plumbing-related. Also, this expands job opportunities for the students by giving them enough training to enter the plumbing field at the third-year level of apprenticeship.

\section{E.9.4 Program Content}

Approximately $20 \%-30 \%$ of the program is spent in classroom sessions, and $60 \%$ on hands-on experience. Approximately $10 \%-20 \%$ of the total program time is spent on teaching basic job skills and job behavior. Half-day sessions every, two weeks are spent in career and job-hunting counseling and training. During the first year of the program, approximately $50 \%$ of the training focused on solar-specific skills, with the remainder spent on allied construction trades, particularly plumbing. The emphasis in the second year has switched to basic construction skills, with only about $25 \%$ of the program spent on solar energy.

Hands-on experience is gained through workshops and actual installations. In the first year of the program, 28 active domestic hot water systems and 37 bread boxes were installed on low-income homes. In addition, a 35-panel solar heating system for the swimming pool at the state mental hospital and a hot water system for use in the dairy at the local community college were installed. During the second cycle, 20 hot water systems will be installed on low-income houses. A one-year service warranty on these installations is provided through Proteus. There is also a manufacturer's guarantee for the active systems.

Major reading materials sources are the Uniform Plumbing Code and Anderson's Solar Home Book. The equipm ent used in the shop includes table saws, radial saws, skill saws, impact wrenches, socket sets, electric screwdrivers, drills, welding and soldering equipment, drill press, hand tools, etc. Some of the collectors (8) and one bread box came from the San Bernardino Westside Community Development Corporation. Other collectors were supplied by Radco. Program participants constructed most of the bread boxes.

The program provides tools and manuals for the students. These items become the property of the students upon completion of the program. Students receive a certificate at the program's end. 


\section{E.9.5 Program Participants}

Candidates are selected from a four-county pool (Kings, Tulare, Kern, and Fresno). During the first year, 27 people were chosen in the initial screening. An eighth-grade level math and English test is given to those initially chosen, and the candidates with the most promising scores are selected to participate in the program. The average number of students in each training program is approximately 11 . To date, 15 people have graduated from the program (it should be noted that drop outs are replaced).

Of approximately 25 students who have started the program, 3 or 4 have not completed the training. The reasons given for not completing the program concerned personal problems, transportation difficulties, and lacking the necessary basic ability level. The seasonal agricultural demand also pulls some people out of Proteus. For two of those who dropped out of the course, one returned to farming and the other went back to school.

Almost all of the program participants are farmworkers. Most were highly motivated, but a few enrolled simply because there were no other jobs available for them. The average formal educational level was low and very few had any construction experience. Some were interested in solar energy as a career but few had any prior knowledge of solar energy.

\section{E.9.6 Student Placement}

The Proteus adult training program tracks graduates through personal contacts. After 90 days, a post-separation follow-up is accomplished through telephone calls and letters.

Program job developers are active in providing students contacts with potential employers. So far, all students have been off ered employment or on-the-job training af ter completing the program. Jobs that some students are now in include a crew leader position in the solar program at Proteus, swimming pool installations, and positions with the state.

The solar industry in the local area is considered to be relatively undeveloped. Rapid expansion, however, is expected because of the movement of several national corporations, such as Butler and Grumman, into the area. These solar manufacturing companies are realizing the advantages of low local labor costs, and they should provide future opportunities for program graduates.

\section{E.9.7 Instruetors}

There are two full-time, paid instructors for the program. One instructor, a master plumber, was recommended to the program through the Office of Appropriate Technology in the State Office of Planning and Research. He became interested in solar energy through a senior citizen program. The other instructor, a recent college graduate with training in engineering and solar energy, was recommended by the Director of the CETA program in Tulare. Experience in solar energy is the major qualification for program instruc tors. 


\section{E.9.8 Interaction with Outside Organizations}

The little interaction this program has had with other training and employment programs has been generally good. Local solar businesses have been supportive and responsive, particularly when the program has been involved in solar energy promotions. Terralite, a company in Hanford, hires exclusively from Proteus. The local construction industry is not highly unionized, so there has been very little interaction with unions. There has been some contact with California State University at Fresno through one of its faculty members, who was a solar consultant to the program.

To date, there have been no solar energy businesses created as spin-offs from the program. Two graduates expressed a desire to start their own business, but were not able to do so.

\section{E.9.9 Problems}

The major problem encountered has been difficulties in obtaining needed equipment quickly. This was caused by the lack of lead time to order the materials, plan the procurement process, and complete necessary paperwork. Some materials are not available locally; e.g., insulated pipes had to be ordered from New Jersey. Based on this experience, program officials concluded that at least three months lead time is necessary to obtain equipment before the actual training can begin. 


\section{E.10 SOLAR ENERGY PROJECT: SAN BERNARDINO WESTSIDE COMMUNTTY DEVELOPMENT CORP.*}

\section{B.10.1 Introduction}

Westside CDC originated as a nonprofit, community-based organization established for the purpose of improving the quality of life of low-income residents on the west side of San Bernardino. After receiving its charter in August 1972, the group began fulfilling its goal by rehabilitating public housing units and retrofitting them with solar equipment using the labor of CETA-eligible workers and funds from the local CETA prime sponsor and the Community Service Administration. Using this project as a guide for its initial programming thrust, Westside CDC expanded into further rehabilitation projects, property management, and vocational training for the disadvantaged youths of the area. As CDC expanded, so did its funding sources. Presently, the group has 15 or more regular sources of funding, including state CETA, the U.S. Department of Housing and Urban Development, the U.S. Department of Energy, and the City and County of San Bernardino.

Besides being active in manufacturing and selling solar collectors, and retrofitting lowincome residents'-homes-with solar systems, Westside CDC also trains people in six different programs: four are solar programs; the other two, rehabilitation programs. Its main drive in training has been providing disadvantaged youths with the skills needed to obtain and hold jobs.

\section{E.10.2 Location and General Facility Description}

The primary facility for the training programs is the Energy Technology Center (ETC), located approximately one mile from Westside CDC's administrative center. This facility houses $7,500 \mathrm{ft}^{2}$ of classroom, laboratory, machine and automotive shops, a reading room, and support of fices.

The ETC also utilizes an additional $12,750 \mathrm{ft}^{2}$ of the CDC facilities for its training. These additional facilities provide ETC with professional counseling services, auxiliary training facilities, additional technical and professional manpower, workrooms, storage areas, administrative services, and a complete $2,250 \mathrm{ft}^{2}$ solar system that supplies 10 homes with space heating and domestic hot water. The CDC also has a limited data collection/retrieval library which is available upon request of the faculty and trainees.

\section{E.10.3 Program Description and History}

The primary objective of thie training programs is to provide work experience, work ethics, and a sense of job responsibility to CETA eligibles, particularly minority youths, in order to equip them with the skills they need to enter the field of solar manufacturing and related industrial machine trades. The programs also prepare young trainees for the social and physical adjustments they must make to work in a plant or factory.

*Source: Information was obtained through an interview with Bill Shaw, Westside CDC's Vice-President of Personnel and Training; the school catalog; and an article in the July 1979 issue of Solarwork. 
Planning for the solar training projects started in 1975. Active in the formulation of the projects and in acquiring the necessary funding were CDC's Executive Director, VicePresident of Personnel and Training, Vice-President of Construction, and an engineer who furnished all the technical expertise needed.

The first solar training program began in 1976. During this cycle, the trainees rehabilitated and retrofitted 10 abandoned houses, for which 72 flat-plate collectors were designed, assembled, and installed. There have been two more training cycles since then. The first cycle lasted a year; the next two, for 6 months. Presently, CDC offers four solar programs every 6 months. The only differences among these programs are their funding sources. One program is funded through the county, one through the city, and the others through the state.

There have been a number of changes in the plograms since 1976. One important change is that the CDC began manufacturing and marketing its own collectors, which not only contributes to hands-on training for the students, but also allows the CDC to earn a small profit. The curriculum has also been refined to place more emphasis on solar applications. Hands-on training primarily involves building hot water systems and collectors. $\mathrm{CDC}$ is also constantly monitoring the industry in order to take advantage of new tech. nological improvements. The graduates of the next training cycle will be receiving vocational certificates as Solar Specialists as a result of the Department of Private Postsecondary Education's accreditation of Westside CDC's solar training programs.

\section{E.10.4 Program Content}

The solar energy specialist training programs are 6 months long and takes place 5 days per week for 8 hours per day. The trainee's time is equally divided into three areas: classroom sessions, workshops, and actual installations. In the classroom, students are instructed on the theoretical aspects of solar energy technology; fundamental English, mathematics, writing, and related skills are reviewed. Hands-on experience is gained through workshops and contracted installations with public housing projects.

The program spends $30 \%$ of its time teaching solar applications; the remainder of the time is spent on teaching general construction skills (see Attachment E-7 for a general course breakdown). The solar training includes production, installation, and maintenance of solar systems and equipment. Within the course of study for the program, there are eight areas of specialization open to the trainees: solar collector fabrication, solar heater fabrication, solar system/component installation, solar system preventive maintenance, solar system design, solar data collection, machine operations, and machine shop work experience.

A flexible training schedule is maintained for each participant based on an assessment of the students' learning abilities in absorbing the theoretical aspects of solar energy and applying classroom knowledge to actual hands-on work. A continual eff ort is also made in teaching basic job behavior, job responsibility, work ethics, and good work attitudes.

The types of solar systems that have been installed by the trainees include 100 bread boxes and flat-plate collectors, 10 fan coil space heating systems, and 1 greenhouse. These installations were funded by CSA, HUD, and the U.S. Department of Energy. The trainees are responsible for the repair of the systems. 
Tools and textbooks are provided to the students. Reading materials include math and English textbooks, a beginning and intermediate blueprint book, and books on general solar theory. The laboratory areas of ETC are equipped with approximately 30 major machine tools which are available to the trainees. Some of the major tools are: power shears, drill presses, crimping machine, burnishing tools, lathes, welding equipment, milling machine, sheetmetal brake, arbor presses, portable tools, sheetmetal rollers, grinders, kick presses, roll formers, power saws, and welders (arc and oxygen-acetylene). Tools are provided to students upon graduation if the graduate's first job requires ownership of such tools.

\section{E.10.5 Program Participants}

The prerequisite for admission into the program is that the candidate be CETA eligible. An intake agency is responsible for initial screening of applicants. The program puts an emphasis on selecting economically disadvantaged youth with an interest in solar from the CDC target areas.

Enrollment in each program totals approximately 25-30 students, and there are approximately 100-120 students in all four solar training programs. The ETC's capacity for enrollment into the solar programs is 150 students per cycle. Most of the enrollees are between 19 and 20 years old, members of minority groups (80\%), high school dropouts, and welfare recipients (90\%). Ten percent of the enrollees are ex-offenders. The program receives many of its participants from the CDC's Summer Work Experience Program for high school dropouts. Participants also generally expressed interest in solar energy.

As of December 1979, there have been approximately 300 graduates. The training programs' attrition rate has been between $3 \%-4 \%$. Reasons given for not completing the program include personal problems, pregnancies, discipline problems, general grievances, and transfers into other training programs.

\section{E.10.6 Student Placement}

Program graduates are placed in jobs through CDC's two full-time job developers. The program keeps track of its graduates through 30-,60-, and 90-day follow-ups. There is an $80 \%$ place ment rate; out of those placed, $60 \%$ have retained employment for at least a year.

According to a survey of 30 solar companies in southern California, opportunities in the solar energy field in the area are presently nil. Therefore, most of the jobs found for graduates are not in the solar field. However, these alternate positions do require the use of other skills that the graduates acquired through their training.

Other barriers to placement and retention of employment are: commuting long distances, the gasoline shortage, lack of transportation, prior judicial commitments, emotional problems, not following program guidelines in the strictest sense, family disruptions, lack of real interest; and inability to deal with other personalities. 


\section{E.10.7 Instruetors}

There are 22 full-time, paid instructors for the programs, 10 of whom are graduates of the programs. The 10 graduates are those who had shown leadership ability and knowledge about solar. Their main responsibilities are to act as lead persons for the trainees and to assist other instructors. Qualifications for the trade instructors are that they have leadership skills and at least 5 years of experience in their specific field.

\section{E.10.8 Interactions with Outside Organizations}

As one of the better known CETA-funded programs in California, CDC has had the opportunity to interact with many other employment programs in the state, usually in an advisory capacity. The program's interaction with local solar businesses is minimal, because it manufactures its own systems. There are no interactions between lucul unions and CDC. Two of the local educational institutions, Cal Poly Pomona and San Bernardino Valley Community College, have supplied the CDC with engineering and accounting assistance. Valley Community College also grants credit hours of work experience to the program's trainees, provided that the trainees enroll in vocational courses at the college.

CDC is now developing a new industrial park in which manufacturing facilities are being built. Among these facilities are a concrete-block manufacturing plant, and two solar manufacturing plants that will be profit-making spin-offs from the CDC.

\section{E.10.9 Problems}

The primary problem has been the CDC's difficulties in obtaining adequate funds for all its activities. 


\section{ATTACHMENT E-7 \\ CLASS DESCRIPTION FOR THE \\ CDC/ENERGY TECHNOLOGY CENTER}

MACHINIST TECHNOLOGY-Clock Hours: 250. Offers work experience and training in machine shop practice, machine shop operators' techniques, and machine shop theory. Practical experience on major machine shop tools and instruction in desirable industrial work habits and attitudes are also taught.

DRAFTING-Clock Hours: 20. Includes techniques of drafting, practical application of mechanical drawing in the machine tool trades, and blueprint reading and drawings used in solar hardware design and assembly.

INDUSTRIAL SUPERVISION-Clock Hours: 20. Covers problems of industrial occupational safety and the application of Cal/OSHA regulations to industrial places of employment.

CETA TRAINEE INDUSTRIAL CAREER DEVELOPMENT-Clock Hours: 20. Includes individual and group counseling on CETA trainee placement in the industrial trades. Job development techniques and outside speakers on industrial career opportunities available to CETA enrollees.

INDUSTRIAL MANUFACTURING PROCESSES-Clock Hours: 40. Offers theory and practice in fabricating industrial products, methods of automation, machining, fabrication properties of metals, plastics, wood and engineering standards/references/shop handbooks. Emphasis on the practical application of manufacturing processes in the field of solar hardware assembly.

MATHEMATICS-Clock Hours: 60 . Covers the metric system of measurements, review of whole numbers, decimals, fractions, percents, ratios, proportions, graphs, statistics, problem solving, and elementary geometry. Emphasis is on the practical application of mathematics as a daily tool of the machinist.

SOLAR TECHNOLOGY-Clock Hours: 450. An overview of the design, assembly, installation, maintenance, and monitoring of active solar systems available at the CDC. Includes information on solar heating, cooling, solar radiation, heat storage, control devices, system component sizing, domestic hot water heating, and collector/heater fabrication. Also includes solar data collection, cost-effectiveness analysis, and the fundamentals of solar retrofitting. 


\section{E.11 SOLAR TECHNICIAN TRAINING PROGRAM: SACRAMENTO-YOLO*}

The Sacramento-Yolo program was a pilot training program developed by the California Office of Appropriate Technology in conjunction with the Office of the State Architect. The purpose of the pilot program was to test the feasibility of training CETA-eligible individuals for jobs in the new, growing solar energy heating and cooling industry. It was hoped that the program would relieve low-income unemployment problems while creating a qualified, available labor force for the developing "labor-intensive techniques and applications of solar technology to urban residences." The program was designed to be transferable to other areas in California and the country.

The training period lasted one year, from October 1, 1976, to September 30, 1977. The training was divided into a hulf-luy of classroom activities and a half-day of shop and fieldwork. Fieldwork consisted of retrofitting state-owned buildings with solar water heating systems. There were 19 CETA-eligible enrollees, of whom two wcrc placed in solar-related jobs.

The project had a four-person, full-time staff that included a Project Director, a trainirig supervisor, and two secretaries. There were also two part-time senior citizen craftspersons: an expert plumber and an expert electrician. The training supervisor, plumber, and electrician contributed the technical expertise needed for the project.

The first pilot program of its kind in California, the project resulted in a number of recommendations for future solar training programs. Among the recommendations is that the program goals should be explicitly stated, given priorities, and used as the basis for a formal statement of program organization and training approach. This should help resolve any possible conflict over whether emphasis should be placed on improving the standard of living for the low-income populace by supplying them with skills necessary for solar energy jobs, or on the actual installation of demonstration solar systems to encourage acceptance of solar technology by urban communities.

Another recommendation was to conduct ongoing evaluations of the students' progress and of training methods to obtain f eedback for possible program revisions. This type of evaluation may be a valuable input to designing a curriculum that will train formerly unskilled or underskilled persons to meet an acceptable skill level. The curriculum should be expansive enough so that graduates would feel adequately prepared to participate and compete effectively in the solar energy industry.

To further improve the program's effectiveness, it was also suggested that it be put on a professional level equal to other educational and training organizations. To accomplish this, the Program Direc tor should be qualified in the educational, technical, and managerial areas; the program should have adequate support services; and the program should be housed in an appropriate building with access to proper equipment, tools, and materials.

*Source: Information was obtained through an evaluation of the program written by Ron Lipton, Executive Director to the SolarCal Office, California State Government. Because of the length of time that has passed since the operation of this program, and the fact that it was a pilot program for experimental purposes, information obtained was not extensive enough to provide a complete a description for the program. 


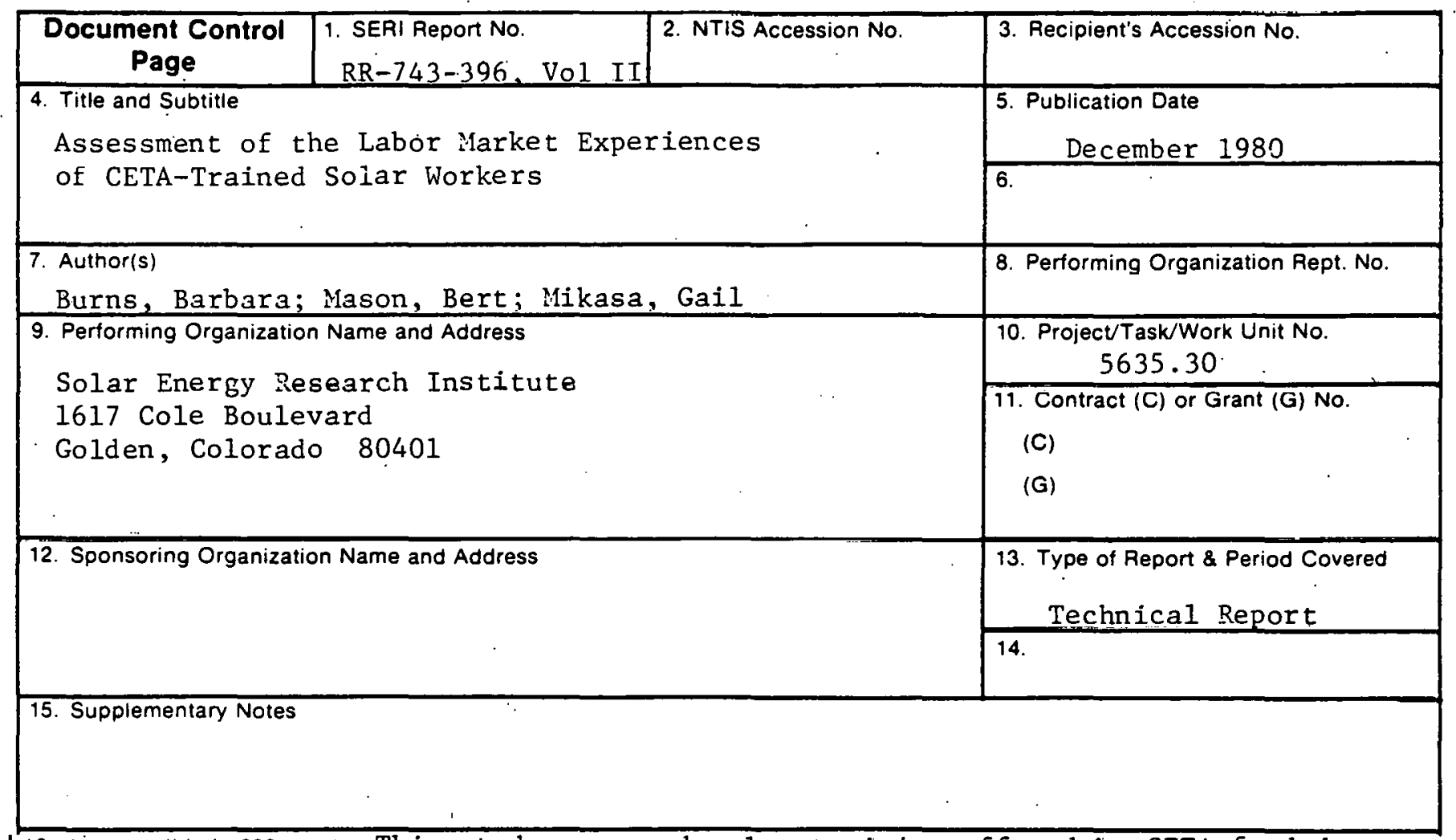

16. Abstract (Limit: 200 words) This study assessed solar training offered by CETA-funded programs and labor market experiences of program graduates. The initial research was restricted to programs within California, because the state is involved in a variety of solar-related activities, including development of jobs and training programs in solar energy. Interviews were conducted with 12 CETA solar training programs and graduates in 1979, in cooperation with California's SolarCal office. Information on graduates includes demographics, educational and work experience, satisfaction with solar training, types of jobs found, wage levels, and job tenure. Program information includes length, types of training, and the number and inds of solar systems installed. Results show that major program problems were: limited funding; shortages of trained instructors; insufficient staff; need for local employment information; need for better derined role for unions; and pressures for high placement rates. The curricula involved general skills, skills specific to solar technologies, and basic job behavior and skills. The training involved both classroom and hands-on experience and was mainly tailored to participants and the local job market. Successful placement of program participants was relatively high; over half the initial job placements involved solar energy. Solar jobs appeared to pay more than nonsolar jobs. Participants generally felt that their training had prepared them adequately for their current work.

17. Duiviment Alialysis

a. Descriptors California ; Data Compilation ; Education $\left(Q_{1}, Q_{2}\right)$; Employment ; Federal Assistance Programs ; Labor ; Local Government ; Manpower $\left(\mathrm{T}_{1}^{2}\right.$ ); Occupations ; Social Services ; Solar Energy $\left(\mathrm{T}_{2}\right)$; Solar Industry ; Work ; Data ; Energy ; Energy

b. Identifiers/Open-Ended Terms Sources; Industry ; Information ; North America ; Numerical Data. ; Renewable Energy Sources ; USA ; Western Region ; Technology

c. UC Categories uiv- -58

18. Availability Statement

National Technical Information Service

U.S. Department of Commerce

5285 Port Royal Road

Springfield, Virginia 22161

19. No. of Pages

140

20. Price

i. 25 